\title{
Macrodoelmatigheid mbo: Inkadering arbeidsmarktperspectief
}

Citation for published version (APA):

Cörvers, F., de Hoon, M. L. A., \& Meng, C. M. (2014). Macrodoelmatigheid mbo: Inkadering arbeidsmarktperspectief. ROA. ROA Reports No. 001 https://doi.org/10.26481/umarep.2014001

Document status and date:

Published: 01/01/2014

DOI:

10.26481/umarep.2014001

Document Version:

Publisher's PDF, also known as Version of record

\section{Please check the document version of this publication:}

- A submitted manuscript is the version of the article upon submission and before peer-review. There can be important differences between the submitted version and the official published version of record.

People interested in the research are advised to contact the author for the final version of the publication, or visit the DOI to the publisher's website.

- The final author version and the galley proof are versions of the publication after peer review.

- The final published version features the final layout of the paper including the volume, issue and page numbers.

Link to publication

\footnotetext{
General rights rights.

- You may freely distribute the URL identifying the publication in the public portal. please follow below link for the End User Agreement:

www.umlib.nl/taverne-license

Take down policy

If you believe that this document breaches copyright please contact us at:

repository@maastrichtuniversity.nl

providing details and we will investigate your claim.
}

Copyright and moral rights for the publications made accessible in the public portal are retained by the authors and/or other copyright owners and it is a condition of accessing publications that users recognise and abide by the legal requirements associated with these

- Users may download and print one copy of any publication from the public portal for the purpose of private study or research.

- You may not further distribute the material or use it for any profit-making activity or commercial gain

If the publication is distributed under the terms of Article $25 \mathrm{fa}$ of the Dutch Copyright Act, indicated by the "Taverne" license above, 


\title{
Macrodoelmatigheid mbo: Inkadering arbeidsmarktperspectief
}

\author{
Frank Cörvers \\ Marloes de Hoon \\ Christoph Meng
}

ROA-R-2014/1 


\section{Colofon}

(C) Researchcentrum voor Onderwijs en Arbeidsmarkt (ROA). Niets uit deze uitgave mag op enige manier worden verveelvoudigd zonder voorafgaande schriftelijke toestemming van de directeur van het ROA.

\section{Researchcentrum voor Onderwijs en Arbeidsmarkt}

School of Business and Economics

Maastricht University

\section{Vormgeving}

ROA secretariaat, Maastricht

\section{Verkoop}

Researchcentrum voor Onderwijs en Arbeidsmarkt

email: secretary-roa-sbe@maastrichtuniversity.nl

website: www.roa.nl

ISBN: 978-90-532I-524-I 


\section{Inhoud}

Voorwoord

I Inleiding I

2 Macrodoelmatigheid en zorgplicht arbeidsmarktperspectief 5

2.I Inleiding 5

2.2 Begrip 'macrodoelmatigheid' 5

2.3 Negatieve gevolgen bij een gebrekkige arbeidsrelevantie van opleidingen

2.4 Zorgplicht en arbeidsmarktrelevantie van opleidingen 9

2.5 Conclusies

3 Analyse van arbeidsmarktindicatoren II

3.I Inleiding II

3.2 Indicatoren voor arbeidsmarktrelevantie I2

3.3 Onderliggende relaties tussen arbeidsmarktindicatoren I4

3.4 Conclusies 2 2I

4 Grenswaardes voor arbeidsmarktrelevantie $\quad 23$

4.I Inleiding $\quad 23$

4.2 Overwegingen bij het vaststellen van grenswaardes 24

4.3 Case-study: de vsv-aanpak 28

4.4 Grenswaardes voor de indicator percentage werkzaam 3I

4.4.I Methode I - Absolute grensbepaling 3I

4.4.2 Methode 2 - Relatieve grensbepaling zonder correcties 35

4.4.3 Methode 3 - Relatieve grensbepaling met correcties 40

4.5 Grenswaardes voor de indicator percentage onderbenutting $\quad 42$

4.5.I Methode I - Absolute grensbepaling 42

4.5.2 Methode 2 - Relatieve grensbepaling 45

4.6 Huidig en toekomstig arbeidsmarktperspectief van beroepsopleidingen $\quad 47$

4.7 Conclusies $\quad 50$ 
5 Invulling van het beoordelingskader $\quad 55$

5.I Inleiding 55

5.2 Leerproces voor onderwijsinstellingen en handhaver 57

5.3 Overzichten van opleidingen met laagste arbeidsmarktrelevantie $\quad 59$

5.4 Aanvullingen op het beoordelingskader 63

5.5 Conclusies 66

6 Conclusies $\quad 69$

$\begin{array}{ll}\text { Literatuur } & 73\end{array}$

$\begin{array}{ll}\text { Bijlage tabellen hoofdstuk } 3 & 75\end{array}$

$\begin{array}{lr}\text { Bijlage tabel hoofdstuk } 4 & 79\end{array}$

$\begin{array}{ll}\text { Bijlage tabellen hoofdstuk } 5 & 83\end{array}$ 


\section{Voorwoord}

In dit rapport wordt op verzoek van het Ministerie van Onderwijs, Cultuur en Wetenschap en het Ministerie van Economische Zaken aan het ROA verslag gedaan van een onderzoek naar een beoordelingskader voor het arbeidsmarktperspectief van beroepsopleidingen. ${ }^{I}$ Dit kader dient ter ondersteuning van de naleefbaarheid en handhaafbaarheid van het arbeidsmarktperspectief van opleidingen in het concept van het wetsvoorstel macrodoelmatigheid mbo, dat de minister van OCW in 2014 naar de Tweede Kamer wil sturen. ${ }^{2}$

De uitvoering van het onderzoek past tevens in de reeds jaren lopende discussie over de macrodoelmatigheid van opleidingen. In 2008 werd de Wet educatie en Beroepsonderwijs (WEB) aangepast en werd er een zorgplicht voor mbo-opleidingen ingesteld. Deze zorgplicht houdt in dat onderwijsinstellingen enkel een opleiding mogen aanbieden als er na afronding van de opleiding voldoende arbeidsmarktperspectief is voor de deelnemers. Het voorliggende onderzoek sluit aan bij de zorgplicht arbeidsmarktrelevantie van onderwijsinstellingen. In een parallel door KBA uitgevoerd onderzoek wordt de nieuw in te voeren zorgplicht doelmatigheid van onderwijsinstellingen nader beschouwd, waarbij het vooral gaat om de kostenefficiëntie en de gewenste minimale schaalgrootte van opleidingen.

Door het kabinet wordt het begrip arbeidsmarktperspectief in het verslag van de internetconsultatie bij het bovengenoemde conceptwetsvoorstel geïnterpreteerd als tijdig een baan op niveau. Er is behoefte aan een indicatie van hoe instellingen met deze zorgplicht om kunnen gaan en op basis van welke indicatoren en grenswaardes een beoordeling van de arbeidsmarktrelevantie van opleidingen kan plaatsvinden. Hiertoe is het gebruik van gegevens met betrekking tot de arbeidsmarktrelevantie van beroepsopleidingen noodzakelijk, en dient er een kader voor de beoordeling van deze gegevens te worden ontworpen.

De auteurs danken de leden van de begeleidingscommissie voor hun commentaar tijdens de bijeenkomsten en hun bijdrage aan dit rapport: Sander Baljé (Ministerie

I. De term beroepsopleiding wordt hier gebruikt voor een cluster van crebo-opleidingen. Hierbij wordt gebruik gemaakt van de koppeltabel zoals door OCW/DUO, Inspectie van het Onderwijs, SBB en MBO Raad ontwikkeld.

2. Zie voor het conceptwetsvoorstel (juni 2013) en het verslag van de internetconsultatie door de minister: http://www.internetconsultatie.nl/macrodoelmatigheid_mbo. Een aangepast voorstel is naar de Raad van State gestuurd voor advies. 
van OCW), Bernard Verlaan (Ministerie van OCW), Udo Teunis (Ministerie van EZ), Stef Böger (Inspectie van het Onderwijs), Niels Muselaers, (Ministerie van Financiën) en Mersiha Tepić (CBS). Ton Eimers (KBA) en Erik Keppels (KBA) worden bedankt voor de prettige samenwerking. Daarnaast zijn de auteurs dank verschuldigd aan Rolf van der Velden (ROA/UM) en Inge de Wolf (Inspectie van het Onderwijs/UM) voor hun adviezen en praktische tips, Annelore Verhagen (ROA/UM) voor haar hulp bij de start van de analyses, en Jaap-Jan Bakker (DUO/OCW) voor de aanlevering van arbeidsmarktgegevens over schoolverlaters. 


\section{Inleiding}

\section{Aanleiding van het onderzoek}

In de brief van 2 april 2012 aan de Tweede Kamer geeft de minister van OCW (Ministerie van OCW, 2OI2) een toelichting op de aanvullende maatregelen gericht op een verdere verbetering van de arbeidsmarktrelevantie, doelmatigheid en toegankelijkheid van het regionale aanbod van mbo-opleidingen. In de brief komen de volgende aandachtspunten aan de orde:

- een grotere transparantie van de informatievoorziening rondom de aansluiting tussen onderwijs en arbeidsmarkt;

- een betere afstemming van het opleidingenaanbod door onderwijsinstellingen onderling en met werkgevers in de regio;

- het invoeren van een escalatiemechanisme als de verschillende onderwijsinstellingen en stakeholders (in het bijzonder de werkgevers) in een regio niet tot afstemming komen;

- het structureel opnemen van de naleving van de wettelijke zorgplicht arbeidsmarktperspectief in het risicogerichte toezicht van de Inspectie van het Onderwijs.

Een jaar later werpt de minister van OCW aan de Tweede Kamer (Ministerie van OCW, 20I3) meer licht op de beoogde verantwoordelijkheidsverdeling voor het opleidingenaanbod in het mbo. Ondanks dat de minister erkent dat veel mbo-instellingen met succes hard werken aan een zo goed mogelijk beroepsonderwijs, wordt er geconstateerd dat bij een aantal onderwijsinstellingen in het mbo teveel de aandacht uitgaat naar groei van het aantal deelnemers. In plaats van groei zou het juist moeten gaan om kwaliteitsverbetering, het optimaal laten aansluiten van het opleidingenaanbod op de behoefte van de arbeidsmarkt en het doelmatig spreiden van het opleidingenaanbod. De minister kondigt nieuwe wetgeving aan, waarin onderwijsinstellingen weliswaar verantwoordelijk blijven voor het opleidingenaanbod, maar waarin de zorgplicht arbeidsmarktperspectief wordt aangescherpt en de handhaving wordt opgenomen in het toezicht door de Inspectie van het Onderwijs. Naar het oordeel van de minister zijn de waarborgen in de huidige Wet Educatie en Beroepsonderwijs (WEB) onvoldoende gebleken, en dient deze te worden aangepast. Het gebrek aan waarborgen uit zich volgens de minister in teveel opleidingen met gediplomeerden die in een werkloosheidsituatie terecht komen of in een baan buiten hun domein of onder hun niveau, en in versnippering en inefficiënte van het regionale opleidingenaanbod. 
Wat betreft de verbetering van de arbeidsmarktrelevantie van opleidingen, worden in de brief van april 2013 vier veranderingen in de wetgeving aangekondigd. Ten eerste wordt met de nieuwe wetgeving een goede en objectieve informatievoorziening voor aankomende deelnemers verankerd. De verantwoordelijkheid voor de informatievoorziening ligt bij de onderwijsinstellingen. Zij zullen de informatievoorziening verbeteren door het opstellen van een studiebijsluiter voor alle opleidingen. Dit zal gebeuren door stichting Samenwerking Beroepsonderwijs Bedrijfsleven (SBB) in samenspraak met alle belanghebbenden.

Ten tweede wordt de bestaande zorgplicht arbeidsmarktperspectief aangescherpt door van de onderwijsinstellingen bij risico op een onvoldoende arbeidsmarktperspectief een verplicht overleg voor te schrijven. Bovendien wordt het arbeidsmarktperspectief ingekaderd door te verwachten dat zij de afstemming van het opleidingenaanbod organiseren binnen de 35 arbeidsmarktregio's. In deze regio's nemen werkgevers, gemeenten en UWV deel om tijdig aansluitingsproblemen tussen vraag en aanbod op de regionale arbeidsmarkt te signaleren en waar nodig actie te ondernemen. Onderwijsinstellingen dienen de stakeholders in de regio te informeren over het starten of afbouwen van opleidingen, en in samenwerking met het regionale bedrijfsleven voldoende aanbod van stageplekken te realiseren voor de (toekomstige) vraag.

Ten derde dienen onderwijsinstellingen de arbeidsmarktrelevantie van hun opleidingenportfolio te onderbouwen in bijvoorbeeld hun jaarverslag. In het kader van de beoogde zelfregulering legt SBB vast hoe het afstemmingsoverleg over de macrodoelmatigheid tussen onderwijsinstellingen en het bedrijfsleven vormt dient te krijgen, waarbij er tevens sprake is van de oprichting van een onafhankelijke geschillencommissie, die wordt ingeschakeld als partijen in een regio niet tot overeenstemming kunnen komen.

Ten vierde zal de Inspectie nadrukkelijker de handhaving van het arbeidsmarktperspectief van opleidingen vormgeven. De handhaving door de Inspectie wordt voorafgegaan door de onder punt drie aangehaalde zelfregulering.

De handhaving door de Inspectie dient als sluitstuk in de wetgeving, en wordt van belang als er onvoldoende terecht komt van het afstemmingsoverleg over een macrodoelmatig opleidingenaanbod in de regio, of als uitspraken van de geschillencommissie onvoldoende worden opgevolgd. Met dit sluitstuk beoogt de minister een sterke prikkel te geven aan de zelfregulering wat betreft het oplossen van aansluitingsvraagstukken in het afstemmingsoverleg, de informatievoorziening over de arbeidsmarktrelevantie van opleidingen en het functioneren van de geschillencommissie.

\section{Doel en aanpak}

De zorgplicht van onderwijsinstellingen behelst de verplichting om bij een risico op onvoldoende arbeidsmarktperspectief van beroepsopleidingen overleg te voeren met 
andere onderwijsinstellingen en werkgevers in de regio om het risico weg te nemen. Het doel van het voorliggende onderzoek is het geven van een voorzet om dergelijke risico's bij opleidingen in kaart te brengen. Op basis van de toekenning van een 'rood vlaggetje' aan een opleiding kan een onderwijsinstelling een signaal krijgen dat er voor de betreffende opleiding nader onderzoek of uitleg nodig is, of actie dient te worden ondernomen bij een bepaalde opleiding.

Verschillende aspecten van het arbeidsmarktperspectief van opleidingen kunnen worden meegenomen in besluiten over het opleidingenportfolio van onderwijsinstellingen en de daarbij horende dialoog met het betrokken bedrijfsleven en andere belanghebbenden. In dit rapport wordt een voorstel gedaan voor een nadere inkadering van de indicatoren voor de beoordeling van de zorgplicht arbeidsmarktperspectief. Dit voorstel is gebaseerd op een verkenning van de beschikbare literatuur, een analyse naar de samenhang tussen verschillende indicatoren voor de arbeidsmarktpositie van schoolverlaters, een analyse van de afwegingen (o.a. bepaling van de grenzen en de risico's) bij de inkadering van de arbeidsmarktrelevantie en de bijbehorende indicatoren, en de gedachtewisseling met de leden van de begeleidingscommissie van het onderzoek.

Om met het laatste te beginnen, is er op basis van de discussie in de begeleidingscommissie een aantal uitgangspunten geformuleerd voor de inkadering. Deze uitgangspunten zijn als volgt:

- Het tijdig kunnen bemachtigen van een baan op niveau door schoolverlaters is het vertrekpunt in het conceptwetsvoorstel van de minister. ${ }^{3}$ Dit zou bij voorkeur ook bij de inkadering een belangrijke rol moeten spelen.

- Voor het toezicht op de naleving van de zorgplicht is er behoefte aan een eenvoudig en toepasbaar kader om de risico's in kaart te brengen. ${ }^{4}$

- Het toekomstig arbeidsmarktperspectief van opleidingen dient zoveel als mogelijk bij de risico-inventarisatie te worden betrokken.

- Vanwege de mogelijke invloed van de conjunctuur op de arbeidsmarktpositie van opleidingen is het voor de hand liggend dat er gebruik wordt gemaakt van relatieve grenzen en meerjarengemiddeldes bij het in kaart brengen van situaties waar een risico bestaat op het niet-naleven van de zorgplicht arbeidsperspectief.

- Voor de naleefbaarheid en handhaafbaarheid is het van belang dat de indicatoren zoveel mogelijk op het niveau van de instelling en de opleiding kunnen worden gemeten. De minister heeft immers bij de handhaving van de wet een relatie met elke individuele instelling.

3. Zie www.internetconsultatie.nl/macrodoelmatigheid_mbo

4. Zie Inspectie van het Onderwijs (20I2) voor de laatste versie van het Toezichtkader BVE. De handhaving van de zorgplicht arbeidsmarktperspectief is beschreven in een notitie over de 'werkwijze'. http://www.onderwijsinspectie.nl/binaries/content/assets/Actueel_nieuwsbrieven/2OI2/toezicht-opzorgplicht-arbeidsmarktperspectief---20I2.pdf 
- Er dient te worden gekeken naar een eerste risico-inschatting met een beperkte set aan indicatoren, en een vervolgfase met meer indicatoren en eventuele kwalitatieve afwegingen om zowel onderwijsinstellingen als de Inspectie van het Onderwijs meer inzicht te kunnen geven in de arbeidsmarktpositie van een beroepsopleiding.

Gegeven de bovenstaande wensen is er in dit rapport voor gekozen, om na een inventarisatie van de literatuur over macrodoelmatigheid, te beginnen met een analyse naar de samenhang tussen de beschikbare arbeidsmarktindicatoren van arbeidsmarktperspectief (zoals werkloosheid, percentage werkzaam en onderbenutting) voor de verschillende beroepsopleidingen met het doel om een beperkt aantal indicatoren te selecteren. Deze analyse wordt uitgevoerd aan de hand van landelijke gegevens van het ROA en het CBS. Vervolgens wordt er gekeken naar de mogelijke grenswaardes van deze indicatoren. Hierbij wordt getracht om langs verschillende wegen te komen tot een minimale (grens)waarde van de indicatoren voor arbeidsmarktrelevantie waaraan de beroepsopleidingen op instellingsniveau moeten voldoen. Ook wordt de invloed van het niveau, de leerweg, de richting en de regio van de beroepsopleidingen in de analyse betrokken. Voorts wordt daarbij het belang van het toekomstig arbeidsmarktperspectief van beroepsopleidingen besproken. In het laatste deel van het rapport wordt nader ingegaan op het proces van beoordelen, en de 'zachtere' en meer kwalitatieve aspecten die bij de beoordeling van de arbeidsmarktrelevantie van opleidingen een rol kunnen spelen.

\section{Opbouw van het rapport}

Dit rapport is als volgt opgebouwd. In hoofdstuk 2 (Macrodoelmatigheid en zorgplicht arbeidsmarktperspectief) staan we eerst stil bij de termen macrodoelmatigheid en arbeidsmarktrelevantie. In hoofdstuk 3 (Analyse van arbeidsmarktindicatoren) werken we de vraagstelling verder uit wat betreft de set van mogelijke indicatoren. Daarnaast staan we in deze paragraaf stil bij de vraag hoe omgegaan dient te worden met de onderliggende relatie van indicatoren en de eventuele noodzaak om indicatoren te clusteren dan wel in een gecombineerde aanpak te analyseren. Hoofdstuk 4 (Grenswaardes voor arbeidsmarktrelevantie) geeft inzicht in de vraagstelling omtrent de manier waarop grenzen vastgesteld dienen te worden. In hoofdstuk 5 (Invulling van het beoordelingskader) wordt gekeken naar het vervolgtraject voor opleidingen met een onvoldoende arbeidsmarktperspectief. In hoofdstuk 6 worden de conclusies getrokken. 


\section{Macrodoelmatigheid en zorg- plicht arbeidsmarktperspectief}

\section{$2.1 \quad$ Inleiding}

In dit hoofdstuk staan we aan de hand van de literatuur stil bij de termen macrodoelmatigheid, zorgplicht en arbeidsmarktrelevantie. We starten in paragraaf 2.2 met het begrip 'macrodoelmatigheid' zoals in dit in de Nederlandse literatuur wordt besproken. In paragraaf 2.3 volgt op basis van internationaal en Nederlands onderzoek een overzicht van het onderzoek naar de consequenties van een gebrekkige transitie van schoolverlaters tussen onderwijs en arbeidsmarkt, en daarmee de mogelijke negatieve (langetermijn)gevolgen van onvoldoende arbeidsmarktrelevantie van opleidingen. In paragraaf 2.4 bespreken we de zorgplicht arbeidsmarktperspectief en de daaraan verbonden arbeidsmarkrelevantie van opleidingen. In de laatste paragraaf volgende de conclusies.

\subsection{Begrip 'macrodoelmatigheid'}

In de Nederlandse beleidsliteratuur wordt het begrip macrodoelmatigheid veelvuldig besproken. In Vink et al. (20I0) wordt benadrukt dat wat als doelmatig wordt beoordeeld afhangt van het perspectief van de belanghebbende, i.c. de overheid, het bedrijfsleven of de onderwijsinstelling. Zo heeft de overheid er belang bij dat tegen zo laag mogelijke kosten (bijv. als percentage van het bruto binnenlands product) een zo hoog mogelijk maatschappelijk rendement kan worden behaald. Rendement kan hierbij worden uitgedrukt in aantal deelnemers, aantal diploma's, doorstroom naar vervolgonderwijs en opleidingsniveau van de bevolking. Het bedrijfsleven heeft er meer belang bij dat er op elk moment voldoende aanbod is van goed gekwalificeerde schoolverlaters. Hier kan men spreken van het zogenaamde externe rendement op de arbeidsmarkt, dus in welke mate schoolverlaters inzetbaar en productief zijn in het bedrijfsleven of bij de overheid. Daarvoor kan worden gekeken naar het salaris van schoolverlaters, de horizontale en verticale aansluiting tussen opleiding en werk, werkloosheid, de aard van het dienstverband, etc. Onderwijsinstellingen kijken daarentegen meer naar het interne rendement van de opleidingen, in termen van 
bijvoorbeeld voortijdig schoolverlaten, studievertraging, etc. Onderwijsinstellingen hebben tevens oog voor de kosten van dure, kleine opleidingen (bijv. in de techniek), de mogelijkheden van de verschillende opleidingen om meer deelnemers te trekken, en de beoordeling door de onderwijsinspectie wat betreft bijvoorbeeld onderwijstijd, curriculum en examinering.

De Onderwijsraad (2012) stelt zogenaamde knipperlichtnormen voor om de schaalgrootte en kostenefficiëntie van opleidingen en de aansluiting met de arbeidsvraag van werkgevers in de regio te kunnen beoordelen. De knipperlichten gaan branden of springen op rood als opleidingen onvoldoende scoren op kostenefficiëntie en arbeidsmarktperspectief.

Het bovenstaande komt terug in het afwegingskader van Eimers (20I2) ten behoeve van het inrichten van een regionaal en sectoraal opleidingenaanbod. 'Macrodoelmatigheid' valt uiteen in drie delen (Eimers, 20I2):

- De arbeidsmarktrelevantie van opleidingen, waarbij het gaat om hoe goed het opleidingenaanbod in een regio aansluit bij de regionale arbeidsvraag van werkgevers;

- De doelmatigheid van opleidingen, onder te verdelen in:

- Kostenefficiëntie, bijv. schaalgrootte in relatie tot de verdeling van het opleidingenaanbod in een regio;

- Kwaliteit en continuïteit, zoals bijv. gemeten door de Onderwijsinspectie wat betreft de onderwijs- en werkprocessen, en de leeropbrengsten van scholen;

- Toegankelijkheid van het onderwijs, waarbij de bereikbaarheid van opleidingen in de regio en zelfs de toelating van jongeren tot deze opleidingen een rol kan spelen.

Ten eerste dient het opleidingenaanbod aan te sluiten bij de (voorspelde) behoefte op de arbeidsmarkt. De arbeidsmarktrelevantie kan worden weergegeven in termen van actuele en toekomstige vraag (uitbreidings- en vervangingsvraag), gedifferentieerd naar opleiding. De arbeidsvraag bepaalt hier de gewenste aard en omvang van het opleidingenaanbod.

Ten tweede moet er sprake zijn van efficiënte organisatie van het onderwijs in een regio. Het opleidingenaanbod kan ondoelmatig zijn als er teveel versnippering is van dezelfde kleine, relatief dure opleidingen aan verschillende ROC's in een regio. Centraal bij deze kostenefficiëntie staat de optimale inzet van publieke middelen op boven-instellingsniveau. Een signaal voor mogelijk ondoelmatig aanbod is als opleidingen minder dan 18 deelnemers hebben, dit in ieder geval met uitzondering van opleidingen die uniek zijn in Nederland en in een specifieke arbeidsvraag voorzien. Ondoelmatigheid wordt risicovol als het gevolgen heeft voor de kwaliteit en continuiteit van het onderwijsproces en de opbrengsten van opleidingen. 
Ten derde is ook de toegankelijkheid voor studiekiezers van belang. Het gaat bijvoorbeeld om de mogelijkheid om een opleiding te volgen in de regio. De potentiële instroom voor het mbo bestaat uit de directe instroom vanuit het vmbo, uit doorstromers en herstarters in het mbo, en uit zij-instromers die werkzaam zijn in een middelbaar of hoger beroep.

Het voorliggende onderzoek sluit aan bij het eerste deel over de arbeidsmarktrelevantie van opleidingen. Dit wordt gekoppeld aan de zogeheten zorgplicht arbeidsmarktperspectief die onderwijsinstellingen hebben. Het tweede deel komt in een parallel door KBA uit te voeren onderzoek aan de orde. Dit is gekoppeld aan de in het wetsvoorstel voorgenomen zorgplicht doelmatigheid van onderwijsinstellingen. ${ }^{5}$ Het derde deel is verweven met beide delen en is al een opdracht voor onderwijsinstellingen (artikel I.3.5 WEB). Regionale Opleidingscentra (ROC's), Agrarische Opleidingscentra (AOC's) en vakinstellingen zullen in onderlinge afstemming en in overleg met het bedrijfsleven keuzes moeten maken welke opleidingen lokaal, regionaal en nationaal moeten worden aangeboden.

\subsection{Negatieve gevolgen bij een gebrekkige arbeidsrelevantie van opleidingen}

Recente gegevens over de arbeidsmarktkansen van gediplomeerden van het mbo laten zien dat de kans dat jongeren anderhalf jaar na het behalen van het mbo-diploma werkloos zijn sterk varieert tussen opleidingen (ROA, 20I3). Terwijl het vijfaarsgemiddelde van het werkloosheidspercentage (periode 2008-20I2) van de meer dan IOo onderzochte (grote) opleidingen gemiddeld $5 \%$ bedraagt, kent bijna één op de vijf opleidingen een werkloosheidspercentage van boven de IO\%, en heeft $7 \%$ van de opleidingen zelfs een werkloosheidspercentage hoger dan $15 \%$. Een significant deel van de opleidingen heeft geen of een hele lage werkloosheid. Naast een aanzienlijke variatie in werkloosheid laat dit onderzoek ook duidelijke verschillen zien in de kans dat jongeren een functie vinden die goed aansluit bij het gevolgde opleidingsniveau. Werkt gemiddeld over alle opleidingen $26 \%$ van de jongeren in een functie die onder het niveau van de afgeronde opleiding ligt, dit is bij ca. $15 \%$ van de opleidingen meer dan de helft van de jongeren. Door jongeren voorafgaand aan de opleidingskeuze al uitgebreid hierover te informeren en ze te dirigeren naar opleidingen met lage werkloosheidspercentages en/of een lage kans op onderbenutting van de capaciteiten, wordt het aan werkloosheid en onderbenutting gerelateerde productiviteitsverlies bij de arbeidsmarktintrede sterk verminderd. Navolgend wordt besproken welke (langetermijn)effecten zich kunnen voordoen in de loopbaan van schoolverlaters als gevolg van werkloosheid en onderbenutting.

5. In het onderzoek door KBA wordt getracht een onderbouwing te geven voor doelmatigheid in termen van het minimumaantal leerlingen dat voor een onderwijsinstelling nodig is om een opleiding kostenefficiënt te kunnen aanbieden. 
Uit de wetenschappelijke literatuur is veel onderzoek bekend over de kans dat werkloosheid een blijvend litteken veroorzaakt ('scarring') in het carrièreverloop (Heckman en Borjas, 1980). Voor Duitsland laten Von Wachter en Bender (2006) zien dat werkloosheid onder jongeren een lager loon tot gevolg heeft aan het begin van de carrière. Echter deze achterstand wordt door jongeren binnen vijf jaar weer ingehaald. Alleen jongeren die ontslagen worden uit grote bedrijven kampen met een blijvende loonachterstand die zij niet meer kunnen inhalen. Voor de VS vinden Mroz en Savage (2006) geen blijvende gevolgen van werkloosheid op jonge leeftijd op de baankans later in de loopbaan (zij vinden wel negatieve effecten op korte termijn), maar ook dat werkloosheid blijvende negatieve gevolgen heeft voor het loon later in de loopbaan.

Voor Nederland laten Schils et al. (2006) zien dat werkloosheid een nadelig korte-termijneffect heeft op de baankans in de loopbaan, maar dat dit negatieve effect na enige tijd (zes jaar) verdwijnt. De auteurs laten verder zien dat werkloosheid ook een negatief effect heeft op het loon later in de loopbaan, en dat dit negatief effect blijvend is: men haalt de achterstand niet meer in. Bovendien laten zij zien dat het negatief effect van werkloosheid op het loon groter is voor vrouwen dan voor mannen. Mooi-Reçi (2008) laat, eveneens voor Nederland, zien dat werkloosheid de kans op herhaalde werkloosheid later in de loopbaan vergroot en dat dit in sterkere mate geldt voor vrouwen dan voor mannen. In deze studie wordt ook een sterk negatief effect van werkloosheid op het loon later in de loopbaan geconstateerd. Fouarge (2009) vergelijkt de positie van jongeren die tijdens de crisis in de periode I98I-I984 op de arbeidsmarkt kwamen met de cohorten die in de periode voorafgaand aan I98I-I984 of in de directe periode daarna intrede makkten op de arbeidsmarkt. Van deze groep is vastgesteld wat hun arbeidsmarktpositie was in de periode $200 \mathrm{I}-2007$, ongeveer 20 jaar later. Zijn analyses zijn consistent met de eerdere bevindingen voor Nederland wat de langetermijneffecten op employability betreft. Wel vindt hij een licht negatief (ca. I\%) effect op het latere salarisperspectief.

Naast het directe gevaar van langetermijneffecten van werkloosheid tijdens de transitie tussen onderwijs en arbeidsmarkt wordt in de literatuur vaak gewezen op de consequenties op korte en lange termijn van een mismatch tussen de functie en de gevolgde opleiding. Er kan onderscheid worden gemaakt tussen de horizontale match, i.e. de vraag of de functie goed aansluit op de gevolgde onderwijssector, en de verticale match, i.e. de vraag of de functie goed aansluit op het niveau van de gevolgde opleiding. Zo stellen bijvoorbeeld Van de Werfhorst (2002) maar ook Heijke et al. (2003) dat werknemers of schoolverlaters die in een beroep terecht komen dat qua richting niet aansluit bij de gevolgde opleiding significant minder verdienen. Hetzelfde geldt ook voor schoolverlaters die qua niveau onder het niveau van de gevolgde opleiding werk vinden (zie bijvoorbeeld Meng, 2006). In ROA (2013a) is het productiviteitsverlies van de mismatch gemeten aan de hand van het salarisverschil in bruto loon tussen recent gediplomeerden die een passende functie vinden en recent gediplomeerden die geen passende functie vinden. Gemiddeld wordt er voor de gediplomeerde schoolverlaters van de onderzochte opleidingsrichtingen een 'wage penalty' van $8 \%$ vastgesteld 
als men buiten in plaats van binnen de eigen richting werkzaam is, en van IO\% indien men onder het niveau van de gevolgde opleiding werkzaam is.

Gediplomeerde schoolverlaters die voor langere tijd in een functie terecht komen die qua niveau onder het gevolgde opleidingsniveau ligt zullen verder met het probleem van 'use it or loose it' geconfronteerd worden. Omdat de aangeleerde vaardigheden niet (volledig) worden benut, zullen deze in de loop van de tijd gaan slijten (zie bijvoorbeeld De Grip et al., 2008 en ROA, 20II). Daarnaast kan een langdurig verblijf in een lagere functie een negatief signaal afgeven naar potentiële toekomstige werkgevers toe waarmee het gevaar ontstaat dat deze groep schoolverlaters qua carrièreontwikkeling achterblijft.

\subsection{Zorgplicht en arbeidsmarktrelevantie van opleidingen}

Uit het bovenstaande blijkt dat het van groot belang is voor zowel werkgevers als schoolverlaters dat onderwijsinstellingen in het mbo (ROC's, AOC's en vakinstellingen) opleidingen aanbieden die een goede intrede op de arbeidsmarkt mogelijk maken. In het mbo is er binnen de landelijke kwalificatiestructuur veel ruimte om nieuwe opleidingen aan te bieden. Als onderwijsinstellingen inspelen op de studievoorkeuren van jongeren (o.a. vanwege de afhankelijkheid in hun bekostiging) zonder dat deze jongeren goed geïnformeerd zijn over het arbeidsmarktperspectief van opleidingen, kan dat leiden tot opleidingen met teveel deelnemers c.q. schoolverlaters in relatie tot de arbeidsvraag. Voor deze opleidingen dreigt het gevaar dat onderwijsinstellingen de zorgplicht arbeidsmarktperspectief niet meer kunnen waarmaken. ${ }^{6}$

Hoewel er reeds sinds augustus 2008 door een aanpassing van de Wet Educatie en Beroepsonderwijs (WEB) een zorgplicht voor mbo-opleidingen bestaat, wordt daar volgens de Inspectie van het Onderwijs (20IO) te weinig invulling aan gegeven door onderwijsinstellingen in het mbo. Het gaat dan om het aanbod aan opleidingen van onderwijsinstellingen en hun informatieverstrekking aan deelnemers. De zorgplicht stelt als voorwaarde aan onderwijsinstellingen dat ze alleen een opleiding aanbieden als er na afronding van de opleiding voldoende arbeidsmarktperspectief is voor de deelnemers. Ondanks de nieuwe zorgplicht gaat het voor onderwijsinstellingen in het mbo echter nog steeds meer om de deelnemersmarkt dan om de arbeidsmarkt. De Inspectie van het Onderwijs constateert dat er door onderwijsinstellingen nog steeds opleidingen worden opgestart met slechte arbeidsmarktvooruitzichten. Ook bleek het voorlichtingsmateriaal voor deze opleidingen vaak een te rooskleurig beeld te schetsen van de arbeidsmarktperspectieven.

De Commissie Macrodoelmatigheid Amarantis (2013) adviseert onderwijsinstellingen om te concurreren op basis van kwaliteit van opleidingen in plaats van marktaan-

6. Ook kunnen er veel kleine opleidingen ontstaan als instellingen toegeven aan de druk van werkgevers om een veelheid aan kwalificatiedossiers aan te bieden, waarmee de zorgplicht doelmatigheid ondergraven kan worden. 
deel, spreekt een voorkeur uit voor een kleinschalige uitvoering van onderwijs los van een eventuele grotere bestuurlijke schaal, en benadrukt het belang van goede gegevens over doelmatigheid. Twee andere adviezen van de commissie die van belang zijn voor het voorliggende onderzoeksvoorstel betreffen ten eerste de focus van het onderwijs op de eigen arbeidsmarktregio qua opleidingenaanbod met daarbij bestuurlijke aandacht voor de zogenaamde 'stakeholders' (gemeentes, UWV, werkgevers). Ten tweede vindt de commissie dat een mbo-instelling alleen een breed spectrum van opleidingen zou moeten aanbieden als de kwaliteit gegarandeerd kan worden en de arbeidsmarkt erom vraagt.

De Onderwijsraad (2012) concludeert in het eerder genoemde advies dat de macrodoelmatigheid van opleidingen in Nederland over het geheel bezien voldoende is, maar dat er wel verbeterpunten zijn. Zo zijn er nog teveel opleidingen waarvan afgestudeerden spijt hebben van de gekozen opleiding. Als er betere informatie wordt gegeven over de studiekeuze, kan het aandeel gediplomeerden dat achteraf spijt heeft mogelijk worden teruggedrongen. Ook het perspectief op de arbeidsmarkt laat voor sommige opleidingen te wensen over, en zijn er teveel kleine opleidingen. ${ }^{7}$

\subsection{Conclusies}

Een indicatie voor een gebrekkige arbeidsmarktrelevantie van opleidingen is dat bij een significant deel van de opleidingen de werkloosheid onder schoolverlaters twee tot drie keer zo hoog is als gemiddeld. Ook is de onderbenutting bij sommige opleidingen veel hoger dan gemiddeld. Vooral door werkloosheid maar ook door mismatch op de arbeidsmarkt (horizontaal of verticaal) ontstaan er grote productiviteitsverliezen bij de arbeidsmarktintrede. Bovendien zijn de effecten van werkloosheid bij de arbeidsmarktintrede ook nog verderop in de loopbaan terug te vinden doordat er een grotere kans op hernieuwde werkloosheid is of een lager loon wordt ('scarring') verdiend. Deze effecten zijn echter klein en verdwijnen vaak met de tijd.

Mede gebaseerd op de in dit hoofdstuk besproken onderzoeken is het kabinet van mening dat de aansluiting van het onderwijs op de arbeidsmarkt en de doelmatigheid van het opleidingenaanbod van groot belang zijn en voor verbetering vatbaar (Ministerie van OCW, 2013). Het kabinet heeft daartoe wetgeving in voorbereiding, waarvoor het voorliggende rapport relevante informatie dient aan te leveren. In de voorgenomen wetgeving wordt onder meer een aanscherping van de bestaande zorgplicht arbeidsmarktperspectief en een nieuwe zorgplicht doelmatigheid voorgesteld.

7. De Onderwijsraad (2012) wijst tevens op de spanning tussen deze elementen. Zo zou een hogere kostenefficiëntie met een grotere schaal van de opleiding bereikt kunnen worden door verbreding van een opleiding of door concentratie van verschillende opleidingen op één locatie. Er komen dan weliswaar meer deelnemers op de opleiding af, maar de opleiding wordt wat minder beroepsgericht met wellicht een slechter arbeidsperspectief tot gevolg. Bovendien hebben jongeren dan minder keuzemogelijkheden in hun directe omgeving waardoor ze meer reistijd hebben of moeten kiezen voor een opleiding die slechter aansluit bij hun interesses. 


\section{Analyse van arbeidsmarkt- indicatoren}

\subsection{Inleiding}

In dit hoofdstuk wordt nader ingegaan op de verschillende arbeidsmarktindicatoren die van belang zijn bij het bepalen van het arbeidsmarktperspectief van opleidingen. Er wordt gezocht naar een kader voor het vaststellen van het arbeidsmarktperspectief van beroepsopleidingen. Daarbij wordt er gekeken naar de brede set van indicatoren die van belang zijn bij de aansluiting tussen onderwijs en arbeidsmarkt. Het gaat in eerste instantie vooral om de arbeidsmarktpositie van schoolverlaters na afstuderen, zoals gemeten door werkloosheid, arbeidsparticipatie, werken onder niveau of buiten de richting, spijt van de opleiding, bruto loon, etc. De indicatoren hebben dus voor een groot deel betrekking op de kans op werk in het verlengde van de opleiding of het (tijdig) vinden van een baan op niveau.

Het doel van de analyses in dit hoofdstuk is na te gaan in hoeverre de indicatoren met elkaar samenhangen dan wel iets aan elkaar toevoegen wat betreft het inzicht over de arbeidsmarktpositie van schoolverlaters. Hiertoe worden correlatie- en factoranalyses uitgevoerd. Op deze wijze wordt er getracht om te komen tot een beperkte set aan indicatoren waarmee een slecht arbeidsmarktperspectief van opleidingen kan worden vastgesteld. Er wordt gebruikt gemaakt van gegevens van zowel het ROA als het CBS. Onder andere vanwege het steekproefkarakter van de schoolverlatersenquêtes van het ROA zijn de schoolverlatersgegevens (nog) niet beschikbaar op instellingsniveau, en wordt er in voor de analyses in dit hoofdstuk gebruik gemaakt van de indicatoren op landelijk niveau. Het gaat er in eerste instantie om de samenhang te bepalen tussen de verschillende indicatoren voor het arbeidsmarktperspectief.

De correlaties tussen arbeidsmarktindicatoren zouden kunnen verschillen voor subgroepen van opleidingen (bijv. naar richting, niveau, leerweg, regio). Mede omdat de gebruikte dataset van schoolverlatersgegevens verdere uitsplitsing moeilijk toelaat, maar ook omdat de opleidingskenmerken van deze subgroepen juist mede bepalend kunnen zijn voor de correlatie tussen de diverse indicatoren, worden er in dit hoofdstuk geen correlatieanalyses uitgevoerd voor de indicatoren binnen deze subgroepen, 
met uitzondering van niveau van de opleiding. Voor opleidingen op de niveaus 2, 3 en 4 wordt er gekeken of de correlaties tussen de indicatoren afwijken van het beeld als alle opleidingen tezamen worden genomen. Er wordt tevens gekeken naar de wijze waarop de indicatoren gemeten worden. Het gaat dan met name om het hanteren van gemiddeldes over verschillende jaren, en de timing van de meting na het afstuderen. Niveau I (de assistenten- of entreeopleidingen) wordt niet meegenomen in de analyses omdat dit niveau geen startkwalificatie biedt voor de arbeidsmarkt en derhalve niet als arbeidsmarktrelevant wordt beschouwd. Ook worden schoolverlaters die na het afronden van een mbo-opleiding zijn doorgestroomd naar een andere vorm van (bekostigd) onderwijs buiten beschouwing gelaten. ${ }^{8}$

In dit hoofdstuk worden in de volgende paragraaf eerst de verschillende arbeidsmarktindicatoren besproken. In paragraaf 3.3 wordt de samenhang tussen de arbeidsmarktindicatoren geanalyseerd. In de laatste paragraaf volgen de conclusies.

\subsection{Indicatoren voor arbeidsmarktrelevantie}

In deze paragraaf wordt aandacht besteed aan verschillende indicatoren die inzicht bieden in het arbeidsmarktperspectief van beroepsopleidingen. De gepresenteerde kwantitatieve indicatoren zijn gericht op het resultaat van de zorgplicht arbeidsmarktperspectief van een individuele instelling. In sommige gevallen zullen de indicatoren elkaar (grotendeels) overlappen, maar ze kunnen elkaar ook aanvullen. Een uitgebreide set van indicatoren wordt nader besproken en geanalyseerd. Hierbij wordt hoofdzakelijk gebruik gemaakt van het Schoolverlatersinformatiesysteem (SIS) van het $\mathrm{ROA}^{9}$, maar worden eveneens indicatoren afkomstig van het CBS meegenomen in de analyses. Over de beschikbaarheid van de gegevens op instellingsniveau is een aparte paragraaf opgenomen. Er wordt a priori een onderscheid gemaakt tussen drie dimensies van arbeidsmarktrelevantie, welke in onderstaande tabel zijn gepresenteerd en op de volgende pagina’s nader worden besproken.

8. In dit hoofdstuk gaat het slechts om het onderzoeken van de samenhang tussen verschillende indicatoren. In het volgende hoofdstuk wordt er wel nader ingegaan op de relevantie van niet alleen van de opleiding, maar ook richting, leerweg, regio en doorstroom.

9. Zie http://www.roa.unimaas.nl/SIS/index.htm 
Tabel 3.1

Kwantitatieve indicatoren voor het arbeidsmarktperspectief

\begin{tabular}{lll}
\hline Arbeidsmarktkenmerk & Indicator & Databron \\
\hline Arbeidsdeelname & Arbeidsparticipatie & CBS (SSB) \\
& Werkloosheid & ROA (SIS) \\
& Intredewerkloosheid & $R O A(S I S)$ \\
\hline Baankenmerken & Deeltijdaanstelling & CBS (SSB), ROA (SIS) \\
& Flexibele aanstelling & CBS (SSB), ROA (SIS) \\
Kwaliteit van de match & Bruto uurloon & CBS (SSB), ROA (SIS) \\
& Spijt van de gekozen opleiding & $R O A(S I S)$ \\
& Goede aansluiting tussen opleiding en werk & ROA (SIS) \\
& Werk op niveau (c.q. onder niveau/ & $R O A(S I S)$ \\
& onderbenutting) & \\
& Werk in het verlengde van de opleiding (binnen & ROA (SIS) \\
& eigen richting) &
\end{tabular}

\section{Arbeidsdeelname}

De drie indicatoren over arbeidsdeelname geven aan in hoeverre gediplomeerde schoolverlaters van mbo aan het werk zijn gekomen. Het aandeel werklozen is bepaald aan de hand van de door schoolverlaters zelf aangegeven arbeidsmarktsituatie anderhalf jaar nadat zij het onderwijs verlieten. De enquêtegegevens zijn opgenomen in het Schoolverlatersinformatiesysteem (SIS). Het percentage werklozen geeft het aandeel schoolverlaters dat werkzoekend is en minder dan 12 uur per week werkt van het totaal aantal schoolverlaters dat zich aanbiedt op de arbeidsmarkt. Schoolverlaters die niet tot de beroepsbevolking behoren zijn dus niet meegenomen bij het berekenen van het werkloosheidspercentage. Dit zijn (I) schoolverlaters die in het vervolgonderwijs zitten en (2) schoolverlaters die minder dan I2 uur per week werken en niet op zoek zijn naar werk én niet in het vervolgonderwijs zitten (Not in Education, Employment or Training, NEET). De SIS-gegevens bevatten eveneens informatie betreffende intredewerkloosheid, doordat schoolverlaters retrospectief wordt gevraagd naar het aantal maanden dat zij zonder succes naar een baan zochten. Een derde indicator is het percentage werkenden welke het CBS uit de Polis-administratie van het UWV haalt en aan DUO-gegevens over de verschillende mbo-opleidingen koppelt in het Sociaal Statistisch Bestand (SSB). Voor de berekening van het percentage werkenden geldt net als voor het percentage werklozen - dat de schoolverlaters die anderhalf jaar na het afronden van de beroepsopleiding aan vervolgonderwijs deelnemen buiten beschouwing worden gelaten. De zogeheten NEET's worden hier echter wél meegenomen bij het berekenen van het percentage werkenden.

Op voorhand kan gesteld worden dat de indicator voor de netto arbeidsparticipatie van het CBS (percentage werkzaam voor 12 uur of meer per week) een groot voordeel heeft ten opzichte van de andere indicatoren voor arbeidsdeelname in de tabel. De indicator percentage werkzaam is namelijk beschikbaar op instellingsniveau voor de 
verschillende beroepsopleidingen, omdat hij gebaseerd is op de koppeling van administratieve gegevens van DUO en de polisadministratie van UWV. Werkloosheid en intredewerkloosheid zijn gebaseerd op de steekproeven van de schoolverlatersenquêtes van het ROA.

\section{Baankenmerken}

Behalve het al dan niet hebben van een betaalde baan, zijn de werkzekerheid, de omvang van de werkzaamheden en honorering belangrijke indicatoren om het succes te bepalen van de transitie tussen onderwijs en arbeidsmarkt. Om deze reden zijn in tabel 3.I de indicatoren werkzaam in deeltijd, werkzaam in flexibele aanstelling en bruto uurloon (gecorrigeerd voor inflatie) opgenomen. Onder een flexibele aanstelling wordt daarbij verstaan een aanstelling als uitzendkracht, oproepkracht e.d. of een tijdelijke aanstelling. Van een deeltijdaanstelling is sprake wanneer iemand een aanstelling van 32 uur of minder per week heeft. ${ }^{10}$ Wat de omvang van de werkzaamheden betreft dient daarbij opgemerkt te worden dat aan het werken in deeltijd werken ook persoonlijke voorkeur ten grondslag kan liggen. Met andere woorden, deeltijd werken is pas een probleem als iemand voltijds zou willen werken. Het bruto uurloon is een indicator voor de arbeidsmarktpositie van een opleiding en de vraagaanbodverhouding. Bovendien geldt dat naarmate de 'mismatch' groter is, de beloning hieronder lijdt.

\section{Kwaliteit van de match tussen opleiding en werk}

De volgende indicatoren van tabel 3.I geven de kwaliteit van de 'match' tussen onderwijs en arbeidsmarkt weer, en zijn deels gebaseerd op de knipperlichtnormen van de Onderwijsraad. De indicator spijt geeft aan of schoolverlaters achteraf bezien al dan niet opnieuw voor dezelfde studie (aan dezelfde onderwijsinstelling) zouden kiezen. Ontevredenheid over de aansluiting tussen opleiding en werk zoals die ervaren wordt onder werkzame schoolverlaters anderhalf jaar na afstuderen is volgens de Onderwijsraad een goede indicator voor de 'mismatch' tussen verworven en benutte vaardigheden. Dit geldt tevens voor het werken onder het niveau (onderbenutting) naar het oordeel van de schoolverlaters. Daarnaast zal ook worden gekeken naar werken in een baan buiten de eigen richting.

\subsection{Onderliggende relaties tussen arbeidsmarktindicatoren}

De onderliggende relatie tussen de indicatoren speelt een cruciale rol in het nader clusteren van indicatoren om de situaties te bepalen waarin het risico van het niet voldoen aan de zorgplicht arbeidsmarktperspectief hoog is. In deze paragraaf worden Pearson correlaties berekend en factoranalyses uitgevoerd.

Io. Overigens definieert het CBS een deeltijdbaan als een baan van minder dan 35 uur per week. 


\section{Pearson correlaties}

De onderlinge samenhang tussen de eerder besproken indicatoren is in tabel 3.2 gepresenteerd aan de hand van Pearson correlaties. De opgenomen indicatoren zijn hoofdzakelijk afkomstig uit de schoolverlatersenquêtes van het ROA (SIS) voor vijf verschillende jaren, te weten 2007 tot 20II. Het gaat om de arbeidsmarktpositie van schoolverlaters gemeten anderhalf jaar na afstuderen. De SIS-indicatoren die zijn opgenomen in de correlatietabel zijn vanuit een databestand met 91.550 schoolverlaters gewogen naar de gehele populatie van mbo-schoolverlaters en vervolgens geaggregeerd naar het niveau van beroepsopleidingen. Een geaggregeerde indicator is telkens de gemiddelde score op een indicator van alle schoolverlaters van een bepaalde beroepsopleiding. Omdat bijna alle indicatoren - op bruto uurloon na - dichotoom gemeten zijn, kunnen de indicatoren op het niveau van beroepsopleidingen worden gepresenteerd als percentages (bijvoorbeeld het percentage werklozen). In de analysen zijn II8 verschillende beroepsopleidingen (Crebo-clusters) opgenomen. Hierbij zijn beroepsopleidingen die op verschillende niveaus worden aangeboden als afzonderlijke beroepsopleidingen beschouwd. ${ }^{\text {II }}$ Naast de SIS-indicatoren is ook een indicator van het CBS opgenomen in de correlatietabel, welke informatie op hetzelfde niveau bevat. ${ }^{12}$ Het betreft hier de indicator 'percentage werkenden' (werkzaam voor meer dan I2 uur per week), waarbij schoolverlaters van drie verschillende jaren ('o7/'o8, '08/'o9 en '09/'Io) bijeen zijn genomen. Hier gaat het om de arbeidsmarktpositie van schoolverlaters gemeten op ongeveer een jaar na afstuderen. Als er een diploma wordt behaald in het schooljaar 2007/2008 wordt de arbeidsmarktpositie gemeten op de laatste vrijdag van september in 2009.

In het algemeen kan worden gesteld dat er grote samenhang bestaat tussen nagenoeg alle indicatoren van arbeidsmarktperspectief. ${ }^{13}$ Slechts voor één van de opgenomen indicatoren geldt dat de samenhang met de overige indicatoren zeer gering of zelfs afwezig is. Het betreft hier het percentage schoolverlaters dat een jaar na afstuderen werkzaam is onder het behaalde opleidingsniveau, ook aangeduid als 'onderbenutting'. Hierop wordt later nader ingegaan. De drie indicatoren die arbeidsdeelname meten (werkloosheid, werkend en intredewerkloosheid) hangen sterk met elkaar samen. Met name het percentage werklozen (ROA) en het percentage werkenden (CBS) correleren hoog met elkaar $(-0,74)$. Dit is uiteraard geen grote verrassing, maar ondersteunt het idee dat deze twee indicatoren grote overlap vertonen en daarmee in zekere mate hetzelfde indiceren.

II. Ter illustratie: Timmerman niveau 2 is niet dezelfde beroepsopleiding als Timmerman niveau 3.

I2. De ordening van verwante mbo-opleidingen gebeurt via een indeling van beroepsopleidingen (Crebokoppeltabel) welke door het Ministerie van OCW, de Inspectie van het Onderwijs, SBB en MBO Raad gezamenlijk is gemaakt. Op deze manier zijn CBS-gegevens eenvoudig te koppelen aan data van SIS. De gebruikte gegevens omtrent de arbeidsmarktpositie van schoolverlaters is afkomstig uit de polisadministratie van het UWV.

13. Ook voor de verschillende niveaus afzonderlijk blijven de correlaties sterk en bovendien significant. De correlaties per opleidingsniveau zijn weergegeven in de bijlage van dit hoofdstuk. 
De verschillende indicatoren van baankenmerken (deeltijdaanstelling, flexibele aanstelling en bruto uurloon) zijn positief significant gecorreleerd met elkaar. Tevens zijn ze sterk gecorreleerd met de indicatoren van arbeidsdeelname. Ook de indicatoren die informatie verschaffen over de kwaliteit van de match tussen de genoten opleiding en de functie die wordt bekleed, hangen over het algemeen sterk samen met arbeidsmarktdeelname. Enkel voor onderbenutting ontbreekt, zoals eerder gezegd, een significante relatie met de arbeidsdeelname. Met andere woorden, er kan worden gesteld dat het percentage schoolverlaters van een beroepsopleiding dat onder het eigen niveau werkzaam is, niet samenhangt met het percentage werkloze schoolverlaters van diezelfde beroepsopleiding. Dat de indicator onderbenutting inderdaad een andere dimensie van arbeidsmarktrelevantie meet wordt verder bevestigd door ter aanvulling uitgevoerde factoranalyses (zie Box 3.I). Opvallend zijn voorts de hoge correlaties van de indicator spijt met vrijwel iedere andere indicator. Zo zijn de correlaties tussen 'spijt' en 'werkloosheid' en tussen 'spijt' en 'werkend' respectievelijk o,6 en $-0,6$. 


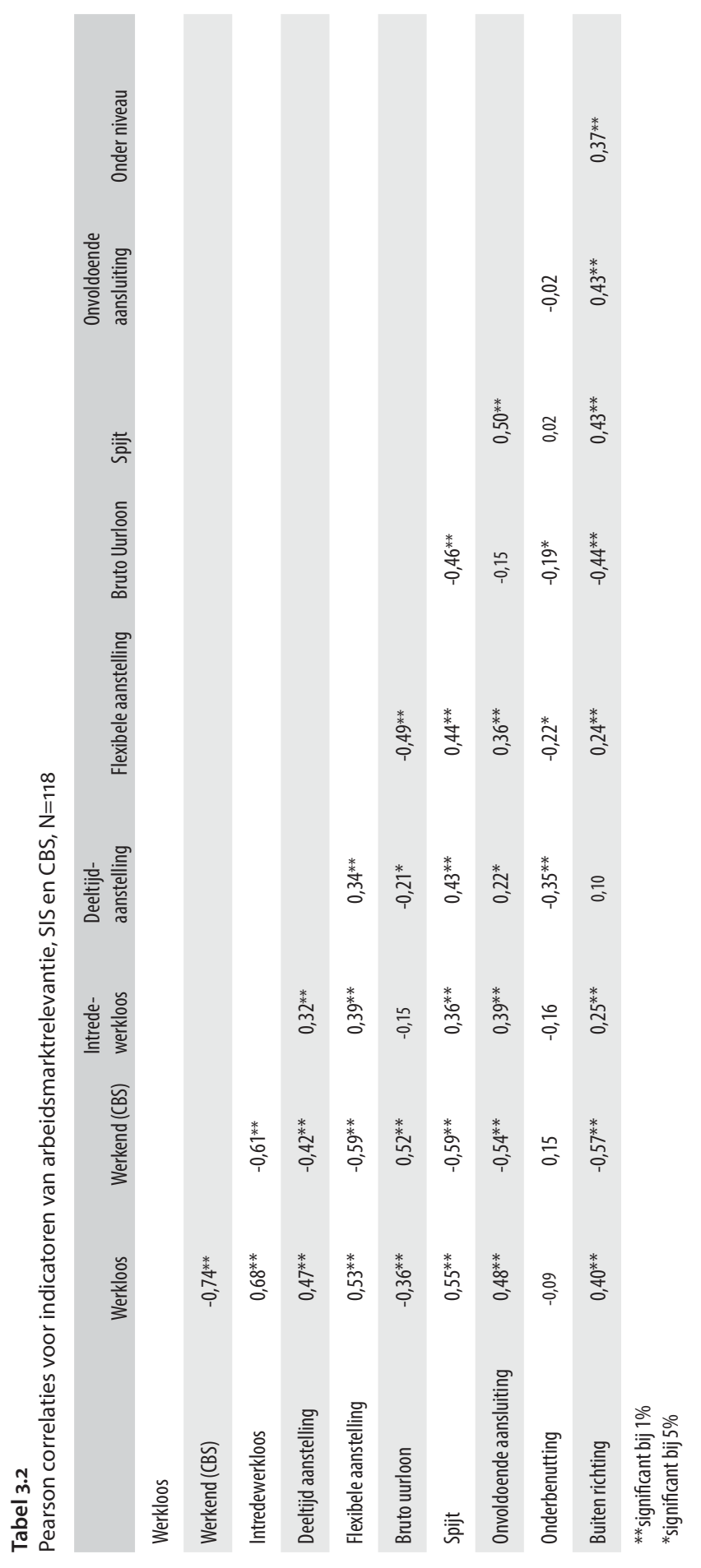




\section{Tekstbox 3.1}

Factoranalyse: Een tweetal dimensies van arbeidsmarktrelevantie

De correlaties uit tabel 3.2 gaven reeds inzicht in de onderlinge relaties van de verscheidene indicatoren. $0 \mathrm{~m}$ na te gaan of er gemeenschappelijke aspecten (factoren) schuilgaan achter de besproken set van indicatoren, zal factoranalyse worden toegepast. Factoranalyse is in eerste instantie een explorerende techniek, waarmee inzicht wordt verkregen in de structuur van de data. De indicatoren die zijn opgenomen in de factoranalyse hebben ten minste een ordinaal meetniveau, waarmee aan één van de voorwaarden van de analysetechniek is voldaan. Bovendien zijn er geen beroepsopleidingen met missende waarden, doordat de opgenomen indicatoren gemiddelden zijn van alle geldige scores van individuen.

De factoranalyse berust op de correlatiematrix tussen indicatoren zoals gepresenteerd in tabel 3.2. Uit de matrix bleek dat er een hoge samenhang bestaat tussen de variabelen. Met een KM0-waarde van 0,793 kan worden gesteld dat factoranalyse hier een geschikte statistische techniek is. Uit de factoranalyse over de opgenomen indicatoren worden twee factoren geëxtraheerd met een eigenwarde groter dan 1. Dit houdt in dat deze factoren tenminste zoveel informatie bevatten als één oorspronkelijke variabele. De eerste factor heeft een eigenwaarde van 4,47 wat inhoudt dat $44,7 \%$ van de totale variantie van alle onderliggende variabelen wordt verklaard door deze factor. De tweede factor heeft een eigenwaarde van 1,62. Samen verklaren de factoren 53,4\% van de totale variantie. In de onderstaande tabel zijn voor alle indicatoren de factorladingen voor beide factoren gegeven. De factorlading is de correlatie tussen de indicator en de factor. Uit tabel 3.3 is op te maken dat de indicator 'werkend' van het CBS het hoogste correleert met de eerste factor $(-0,92)$. Met uitzondering van onderbenutting correleren ook de overige indicatoren hoog met de eerste factor. De indicator onderbenutting correleert zwak negatief met de eerste factor. Op basis van de factormatrix kan worden gesteld dat onderbenutting een andere dimensie van arbeidsmarktrelevantie meet dan de overige kenmerken. Het werken buiten richting blijkt met 0,537 eveneens hoog te correleren met deze tweede factor, maar diezelfde indicator laadt eveneens hoog op de eerste factor. Dit duidt op een zogenaamde 'dubbellading'.

Tabel 3.3

Factormatrix met de extractiemethode Principale Factoranalyse

\begin{tabular}{lcc}
\hline & \multicolumn{2}{c}{ Factor } \\
Arbeidsmarktindicator & 1 & 2 \\
\hline Werkloos & 0,827 & $-0,105$ \\
Werkend (CBS) & $-0,916$ & 0,013 \\
Intredewerkloos & 0,624 & $-0,184$ \\
Deeltijd aanstelling & 0,496 & $-0,330$ \\
Flexibele aanstelling & 0,647 & $-0,138$ \\
Bruto uurloon & $-0,526$ & $-0,269$ \\
Spijt & 0,706 & 0,086 \\
Onvoldoende aansluiting & 0,583 & 0,055 \\
Onderbenutting & $-0,093$ & 0,815 \\
Buiten richting & 0,574 & 0,537 \\
\hline
\end{tabular}

\section{Samenhang tussen verschillende indicatoren voor arbeidsdeelname}

Zoals eerder aangegeven zijn zowel arbeidsdeelname-indicatoren van het ROA als van het CBS meegenomen in de analyses. Werkloosheid is met de schoolverlatersen- 
quêtes van het ROA (SIS) vastgesteld voor schoolverlaters anderhalf jaar nadat zij het onderwijs verlieten. Intredewerkloosheid is retrospectief bevraagd. Het CBS stelt de arbeidsmarktpositie van schoolverlaters op twee verschillende momenten vast, te weten: op het moment dat de schoolverlater het onderwijs verlaat ${ }^{14}$ en een jaar nadat de schoolverlater het onderwijs heeft verlaten. ${ }^{\mathrm{Is}}$ Beide metingen zijn op het niveau van de beroepsopleidingen beschikbaar en kunnen dus worden vergeleken met de SIS-gegevens. In tabel 3.5 wordt nog nadere toelichting gegeven op de wijze waarop de indicatoren zijn gemeten.

Tabel 3.4

Correlatiematrix van indicatoren voor arbeidsmarktdeelname, ROA/SIS en CBS/SSB

\begin{tabular}{|c|c|c|c|c|}
\hline & Werkloos (ROA) & $\begin{array}{c}\text { Intredewerkloos } \\
\text { (ROA) }\end{array}$ & $\begin{array}{l}\text { Werkend T0 } \\
1 \text { jaar (CBS) }\end{array}$ & $\begin{array}{l}\text { Werkend T0 } \\
3 \text { jaar (CBS) }\end{array}$ \\
\hline Intredewerkloos (ROA) & $0,68^{*}$ & & & \\
\hline Werkend T0 1 jaar (CBS) & $-0,61^{*}$ & $-0,57^{*}$ & & \\
\hline Werkend T0 3 jaar (CBS) & $-0,72^{*}$ & $-0,58^{*}$ & $0,90^{*}$ & \\
\hline Werkend T1 3 jaar (CBS) & $-0,74^{*}$ & $-0,61^{*}$ & $0,86^{*}$ & $0,94^{*}$ \\
\hline
\end{tabular}

* Significant bij $5 \%$

Tabel 3.5

Toelichting op verschillende indicatoren voor arbeidsdeelname

\begin{tabular}{|c|c|c|c|}
\hline Databron & Indicator & Gebruikte cohorten (schoolverlaters) & Meetmoment \\
\hline \multirow[t]{2}{*}{ ROA } & Werkloos & $\begin{array}{l}2006 / 2007,2007 / 2008,2008 / 2009,2009 / 2010, \\
2010 / 2011\end{array}$ & 1,5 jaar na verlaten onderwijs \\
\hline & Intrede-werkloos & $\begin{array}{l}2006 / 2007,2007 / 2008,2008 / 2009,2009 / 2010 \\
2010 / 2011\end{array}$ & $\begin{array}{l}1,5 \text { jaar na verlaten onderwijs } \\
\text { (retrospectief) }\end{array}$ \\
\hline \multirow{3}{*}{ CBS } & $\begin{array}{l}\text { Werkend T0 } \\
1 \text { jaar }\end{array}$ & $2009 / 2010$ & september na verlaten onderwijs \\
\hline & $\begin{array}{l}\text { Werkend T0 } \\
3 \text { jaar }\end{array}$ & $2007 / 2008,2008 / 2009,2009 / 2010$ & september na verlaten onderwijs \\
\hline & $\begin{array}{l}\text { Werkend T1 } \\
3 \text { jaar }\end{array}$ & $2007 / 2008,2008 / 2009,2009 / 2010$ & 1 jaar na verlaten onderwijs \\
\hline
\end{tabular}

De sterke samenhang tussen de indicatoren werkloosheid en intredewerkloosheid zoals gemeten binnen het SIS - was eerder al getoond. Uit de correlaties in tabel 3.5 blijkt de SIS-indicator werkloosheid eveneens sterk samen te hangen met de verschillende CBS-indicatoren van arbeidsdeelname welke in bovenstaande tabel zijn toegelicht.

I4. Bijvoorbeeld, in het geval van het schooljaar 2007/'o8 is dit de laatste vrijdag van september in 2008.

I5. Bijvoorbeeld, in het geval van het schooljaar 2007 /'o8 is dit de laatste vrijdag van september in 2009 . 


\section{Samenhang tussen onderbenutting en andere indicatoren}

Uit de correlatie- en factoranalyses kwam naar voren dat alle indicatoren behalve onderbenutting hoog correleren met arbeidsdeelname (percentage werkloosheid of percentage werkzaam). Bovendien bleek de indicator onderbenutting nauwelijks samen te hangen met de meeste overige indicatoren. Tot nu toe is er in de analyse telkens één indicator voor onderbenutting meegenomen, welke is vastgesteld aan de hand van de vraag: "Welk opleidingsniveau werd door uw werkgevers voor deze functie minimaal vereist?" Aan de hand van de factoranalyse moest worden geconcludeerd dat onderbenutting gemeten met deze vraag een andere dimensie van arbeidsmarktaansluiting meet dan de overige indicatoren. Een heldere duiding van deze dimensie is echter niet voor de hand liggend. ${ }^{16}$ Wel kan worden gesteld dat het werken buiten de opleidingsrichting eveneens sterk samenhangt met deze tweede dimensie.

Een tweede indicator van 'onderbenutting' is vastgesteld op basis van de vraag: "In welke mate worden in uw huidige functie uw kennis en vaardigheden benut?" Bij deze vraag wordt onderbenutting gezien als het niet optimaal benutten van de kennis en vaardigheden van een schoolverlater, en wordt bij het bepalen van onderbenutting expliciet rekening gehouden met de capaciteiten van de respondent in plaats van zijn of haar formele opleidingsniveau. Onderbenutting kan er dan ook op wijzen dat de verworven kennis en vaardigheden niet optimaal benut wordt omdat men in een andere richting werkt dan waarvoor men is opgeleid. Beide indicatoren voor onderbenutting zijn in tabel 3.6 opgenomen als onderbenutting(I) en onderbenutting(2). Ook is er voor elke combinatie van verticale en horizontale aansluiting (op niveau \& binnen richting, op niveau $\&$ buiten richting, onder niveau $\&$ binnen richting, onder niveau $\&$ buiten richting) een dummy opgenomen in de correlatiematrix.

Tabel 3.6

Correlatiematrix van indicatoren voor werken onder niveau (onderbenutting) en buiten richting

\begin{tabular}{|c|c|c|c|c|c|c|c|}
\hline & $\begin{array}{l}\text { Werk- } \\
\text { Loos }\end{array}$ & $\begin{array}{l}\text { Onder- } \\
\text { benutting } \\
\text { (1) }\end{array}$ & $\begin{array}{l}\text { Onder- } \\
\text { benutting } \\
(2)\end{array}$ & $\begin{array}{l}\text { Buiten } \\
\text { richting }\end{array}$ & $\begin{array}{l}\text { Op niveau\& } \\
\text { binnen } \\
\text { richting }\end{array}$ & $\begin{array}{l}\text { Op niveau } \\
\& \\
\text { buiten } \\
\text { richting }\end{array}$ & $\begin{array}{l}\text { Onder } \\
\text { niveau } \\
\& \\
\text { binnen } \\
\text { richting }\end{array}$ \\
\hline Onderbenutting(1) & $-0,09$ & & & & & & \\
\hline Onderbenutting(2) & $0,45^{* *}$ & 0,08 & & & & & \\
\hline Buiten richting & $0,40^{* *}$ & $0,37^{* *}$ & $0,48^{* *}$ & & & & \\
\hline Op niveau \& binnen richting & $-0,13$ & $-0,83^{* *}$ & $-0,29 * *$ & $-0,74^{* *}$ & & & \\
\hline Op niveau \& buiten richting & $0,37^{* *}$ & $-0,19^{*}$ & $0,38^{* *}$ & $0,71^{* *}$ & $-0,39 * *$ & & \\
\hline Onder niveau \& binnen richting & $-0,33^{* *}$ & $0,73^{* *}$ & $-0,21^{*}$ & $-0,22^{*}$ & $-0,49^{* *}$ & $-0,35^{* *}$ & \\
\hline Onder niveau \& buiten richting & $0,22^{*}$ & $0,69^{* *}$ & $0,34^{* *}$ & $0,77^{* *}$ & $-0,70^{* *}$ & 0,10 & 0,00 \\
\hline
\end{tabular}

I6. Zie voor een uitgebreide analyse van onderbenutting Coenen et al. (2009). Onderbenutting komt relatief vaak voor onder schoolverlaters met lage eindcijfers. Dat betekent dat een match met een lager baanniveau niet per se op een mismatch hoeft te duiden. 
De correlaties in bovenstaande tabel laten zien dat er geen samenhang bestaat tussen de verschillende metingen van onderbenutting. Een tweede belangrijke constatering is dat de tweede indicator van onderbenutting - waarbij schoolverlaters aangegeven dat in de huidige functie kennis en vaardigheden (gedeeltelijk) onbenut blijven positief samenhangt met het percentage werklozen. Dezelfde indicator voor onderbenutting blijkt daarnaast sterk samen te hangen met het percentage schoolverlaters dat buiten de opleidingsrichting werkzaam is. Dit betekent dat de tweede maatstaf voor onderbenutting vermoedelijk naast het werken onder niveau ook (deels) het werken buiten de (opleidings)richting meet. Kennis en vaardigheden kunnen immers ook binnen een functie op niveau onderbenut blijven, om de eenvoudige reden dat het werkveld of sector waarin de schoolverlater terecht komt niet (geheel) aansluit bij de gevolgde opleidingsrichting. Het is kortom moeilijk vast te stellen wat er met de tweede indicator van onderbenutting wordt gemeten. Om deze reden is besloten de eerste indicator van onderbenutting aan te houden ter aanvulling op de indicator percentage werkzaam.

\subsection{Conclusies}

Uit de analyses van dit hoofdstuk komt duidelijk naar voren dat het zinvol is om beroepsopleidingen te beoordelen op twee dimensies, waarbij de ene dimensie in belangrijke mate de arbeidsdeelname weerspiegelt en de andere dimensie de onderbenutting. De indicatoren die daarvoor het meest geschikt zijn, zijn het percentage werkzaam van het CBS en de onderbenutting van het ROA. De eerste indicator blijkt sterk te correleren met allerlei andere aansluitingsindicatoren, waaronder werkloosheid, spijt van de opleiding, werken buiten richting. Bovendien is deze indicator het gemakkelijkste op instellingsniveau te genereren omdat er gebruik wordt gemaakt van administratieve gegevens. De indicator onderbenutting geeft in aanvulling hierop nog extra informatie over de aansluiting. Het nadeel van deze indicator is echter dat nog moet worden bezien of er op instellingsniveau voldoende betrouwbare informatie kan worden gegenereerd over de onderbenutting van beroepsopleidingen. 



\section{Grenswaardes voor arbeidsmarktrelevantie}

\subsection{Inleiding}

Bij de vaststelling van de grenswaardes waaraan opleidingen minimaal aan zouden moeten voldoen, wordt uitgegaan van de uitkomsten van het vorige hoofdstuk. Er is gebleken dat er twee indicatoren centraal staan bij de vaststelling van het arbeidsmarktperspectief van opleidingen: percentage werkzaam (CBS) en percentage onderbenutting (ROA). Deze twee indicatoren sluiten goed aan bij het streven van de minister van OCW (Ministerie van OCW, 20I3a) dat onderwijsinstellingen ervoor dienen te zorgen dat schoolverlaters tijdig een baan op niveau kunnen vinden. ${ }^{17}$

Hieronder wordt, bij wijze van voorbeeld voor het vaststellen van grenswaardes, een aantal mogelijk afspraken geformuleerd tussen onderwijsinstellingen en het ministerie of andere stakeholders voor het percentage werkzaam van schoolverlaters van een bepaalde opleiding. Binnen ' $x$ ' jaar stijgt het percentage werkzaam:

- naar een waarde van minimaal 70\% werkzaam;

- naar minimaal het landelijke gemiddelde van deze opleidingen;

- naar minimaal de mediane waarde van deze opleidingen;

- naar de waarde die minimaal overeenkomt met de top 30\% van deze opleidingen op landelijk niveau;

- naar de waarde die minimaal overeenkomt met de top 80\% van opleidingen op niveau 2 op regionaal niveau;

- naar de waarde die minimaal overeenkomt met de top 90\% van opleidingen op niveau 3 voor de beroepsopleidende leerweg in de richting economie op landelijk niveau.

Het is duidelijk dat er allerlei varianten kunnen worden bedacht die een prikkel geven aan een onderwijsinstelling om de arbeidsmarktrelevantie van de betreffende opleiding te verbeteren. Het gaat daarbij onder andere om het vaststellen van absolute of

I7. De minister (Ministerie van OCW, 2013a) is van mening dat het tijdig vinden van een baan op niveau, zeker bij laagconjunctuur, veel belangrijker is dan het vinden van een baan die precies aansluit bij de opleiding (met andere woorden: een baan in het verlengde van de opleiding). 
relatieve waardes, het al dan niet rekening houden met de specifieke kenmerken van de opleiding, zoals leerweg, niveau, richting, en het formuleren van grenswaardes in termen van een- of meerjarige gemiddeldes.

In de volgende paragraaf wordt eerst stilgestaan bij de hierboven genoemde overwegingen bij het vaststellen van grenswaardes van indicatoren, zoals percentage werkzaam of percentage onderbenutting. Vervolgens komt in paragraaf 4.3 de aanpak onder voortijdig schoolverlaters (vsv'ers) aan de orde als voorbeeld van hoe grenswaardes kunnen worden vastgesteld. In paragraaf 4.4 en 4.5 worden achtereenvolgens de afleiding van absolute en relatieve grenswaardes voor de indicatoren percentage werkzaam en percentage onderbenutting besproken. In paragraaf 4.6 wordt er gekeken waarom en hoe het toekomstperspectief in de beoordeling van de arbeidsmarktrelevantie van beroepsopleidingen moet worden betrokken. Dit hoofdstuk sluit af met enkele conclusies.

\subsection{Overwegingen bij het vaststellen van grenswaardes}

\section{Doel van grenswaardes}

Een grenswaarde voor de arbeidsmarktrelevantie geeft aan in welke mate een bepaalde opleiding, gegeven de zorgplicht arbeidsmarktperspectief, extra aandacht behoeft van de onderwijsinstelling. Een grenswaarde moet een instelling alert maken op potentieel risicovolle situaties bij opleidingen die teveel schoolverlaters hebben in relatie tot de vraag op de arbeidsmarkt. Onderwijsinstellingen dienen naar aanleiding van die vaststelling een nadere analyse te maken van de ontstane arbeidsmarktsituatie en waar nodig actie te ondernemen. Een grenswaarde kan dus worden opgevat als een signaal, maar biedt tevens een grens waaraan onderwijsinstellingen op korte of langere termijn dienen te voldoen, tenzij bijzondere omstandigheden een (tijdelijke) afwijking ervan rechtvaardigen. Grenswaardes dienen de macrodoelmatigheid van opleidingen te verbeteren, hier in het bijzonder de arbeidsmarktrelevantie van opleidingen. Dat betekent dat er gezocht moet worden naar grenzen die onderwijsinstellingen ertoe aanzetten maatregelen te nemen die de arbeidsmarktrelevantie van hun opleidingen zo veel als mogelijk verbetert. ${ }^{18}$

In welke mate onderwijsinstellingen daadwerkelijk de arbeidsmarktpositie van opleidingen gaan verbeteren en de afgesproken grenswaardes weten te halen, is van diverse factoren afhankelijk. Als onderwijsinstellingen calculerend handelen, waar men vanuit mag gaan, dan zullen ze de kosten van het halen van de grenswaarde afwegen

I8. Overigens is het aangeven van grenswaardes voor opleidingen één van de instrumenten. Er zijn allerlei vormen van prikkels, inclusief prestatiebeloning, voor onderwijsinstellingen denkbaar. Hierover is bijvoorbeeld wat betreft de prestaties van scholen en leraren al de nodige literatuur beschikbaar. De wijze waarop scholen de arbeidsmarktrelevantie van opleidingen kunnen verbeteren wordt nader toegelicht in hoofdstuk 5 . 
tegen de baten. Dat betekent dat de afgesproken doelstellingen realistisch en haalbaar moeten zijn gegeven de inspanningen die daarvoor verricht moeten worden. Als de lat te hoog ligt kunnen onderwijsinstellingen ontmoedigd raken en heeft het hanteren van een grenswaarde wellicht een averechts effect. Anderzijds moet er natuurlijk voor het realiseren van beleidsdoelstellingen van het ministerie ook voldoende progressie geboekt worden. De afweging voor onderwijsinstellingen tussen kosten en baten wordt beïnvloed door de sancties die verbonden zijn aan het niet halen van de doelstellingen. De sancties kunnen uiteenlopen van negatieve publiciteit in de media en onder studiekiezers, tot en met de sluiting van de opleiding door de minister. Behalve de kosten kunnen natuurlijk ook de baten worden beïnvloed, door onder andere positieve publiciteit (denk bijvoorbeeld aan het predicaat 'excellente scholen') en door prestatiebeloningen te geven aan scholen.

\section{Criteria voor grenswaardes}

Bij het vaststellen van grenswaardes voor het verbeteren van de arbeidsmarktrelevantie van opleidingen zijn er verschillende criteria van belang, waaraan de vastgestelde grenswaardes bij voorkeur dienen te voldoen. De grenswaardes dienen bij voorkeur de volgende eigenschappen te hebben.

- Probleemgericht: De grenswaarde moet daadwerkelijk een potentieel probleem signaleren, en attendeert onderwijsinstellingen op ongewenste situaties. Het gaat er in dit onderzoek vooral om dat de beroepsopleidingen (volgens de afgesproken koppeltabel) met het slechtste arbeidsmarktperspectief boven tafel komen. Er dienen dus grenswaardes bepaald te worden voor een onvoldoende arbeidsmarktperspectief bij de indicatoren percentage werkzaam en onderbenutting.

- Realistisch: Een realistische grenswaarde zet onderwijsinstellingen aan tot gewenst gedrag. De grenswaarde is haalbaar en tegelijkertijd draagt de realisatie van de grenswaarde significant bij aan het doel, namelijk het verbeteren van de arbeidsmarktrelevantie van opleidingen.

- Eenvoudig: Een grenswaarde moet duidelijk en herkenbaar zijn, zowel voor onderwijsinstellingen als voor de instantie die gaat toezien op het naleven van de vastgestelde grenswaarde, bijvoorbeeld de Inspectie van het Onderwijs. Dat betekent tevens dat er goede arbeidsmarktgegevens beschikbaar moeten zijn voor de vaststelling van de grenswaarde en de door de onderwijsinstellingen gerealiseerde waardes voor de betreffende opleidingen.

- Robuust: De grenswaarde dient niet al te zeer te schommelen, ze moet dus relatief ongevoelig zijn voor veranderingen in het onderwijs of op de arbeidsmarkt.

\section{Absolute versus relatieve grenzen}

Als er gesproken wordt over grenswaardes voor de arbeidsmarktrelevantie, dan is in het vorige hoofdstuk gebleken dat het percentage werkzaam en het percentage onder- 
benutting de belangrijkste indicatoren zijn. Om de arbeidsmarktrelevantie van opleidingen te verbeteren, wordt er in dit rapport vanuit gegaan dat er doelen worden afgesproken die nagestreefd of gehaald moeten worden door onderwijsinstellingen. De doelen worden geformuleerd aan de hand van grenswaardes en kunnen zowel absoluut als relatief zijn. Absolute grenswaardes kunnen slaan op een percentage werkzaam of onderbenutting dat gehaald moet worden door de onderwijsinstellingen voor de betreffende opleidingen. Met een relatieve grenswaarde wordt bedoeld dat onderwijsinstellingen voor hun opleidingen een plaats in de rangorde van opleidingen moeten zien te halen. In de rangorde zijn alle opleidingen, al dan niet ingedeeld naar leerweg, niveau, richting, gerangschikt naar het percentage werkzaam of onderbenutting (op basis van bijvoorbeeld percentielen).

Of er gekozen moet worden voor absolute of relatieve grenzen, hangt af van het gewicht dat men toekent aan de eerder genoemde criteria voor het vaststellen van grenswaardes. Zoals gesteld dienen de grenswaardes probleemgericht, realistisch, eenvoudig en robuust te zijn. Duidelijk is dat absolute grenswaardes het eenvoudigst zijn. Absolute grenzen waaraan onderwijsinstellingen moeten voldoen hebben als voordeel dat ze aan duidelijkheid niets te wensen overlaten. Een onderwijsinstelling moet bijvoorbeeld minimaal $80 \%$ halen voor het percentage werkzaam van de schoolverlaters van de diverse beroepsopleidingen. Absolute grenzen worden afgeleid van bijvoorbeeld een gemiddelde waarde of een percentielscore van opleidingen in het jaar dat het beleid is gestart of het toezicht is verscherpt. ${ }^{19}$ Relatieve grenswaardes geven daarentegen aan dat opleidingen die tot de (IO\%, 20\%, etc.) slechtst scorende opleidingen behoren, aan verhoogd risico blootstaan en extra toezicht nodig hebben. Onderwijsinstellingen weten daardoor niet van te voren welke beleidsinspanningen ze moeten leveren om de relatieve grens te halen, omdat ze mede afhankelijk zijn van hoe goed andere onderwijsinstellingen presteren. De relatieve grenswaarde is dus minder eenvoudig te gebruiken, en ook minder probleemgericht (i.e. het lage percentage werkzaam of onderbenutting) omdat de beleidsinspanningen van alle onderwijsinstellingen medebepalend zijn voor het al dan niet behalen van de grenswaarde.

Van belang is dat zowel absolute als relatieve grenswaardes realistisch zijn, dat wil zeggen dat de hoogte van de grenswaarde een positieve prikkel moet opleveren voor de onderwijsinstellingen. Uit ervaringen van de Inspectie van het Onderwijs blijkt dat absolute grenzen perverse prikkels kunnen geven aan onderwijsinstellingen die boven de absolute norm presteren, terwijl relatieve normen ontmoedigend kunnen werken omdat er altijd een deel van de opleidingen onder de grenswaarde zit. Dit laatste kan een probleem vormen als de populatie van scholen na enkele jaren aanzienlijke vooruitgang heeft geboekt met het verbeteren van de arbeidsmarktrelevantie van opleidingen. De algehele verbetering van de arbeidsmarktrelevantie kan gelegen zijn in de economische conjunctuur, maar ook in maatregelen van onderwijsinstellingen

19. Merk op dat absolute grenzen toch vaak worden afgeleid van de score van een groep als geheel, of van een deel van de groep, uitgaande van een bepaalde startsituatie. Het hanteren van een gemiddelde als grenswaarde kan voor veel opleidingen echter te hoog gegrepen zijn. 
ter verbetering van de aansluiting tussen de aangeboden beroepsopleidingen en de arbeidsvraag. Het probleem voor de relatieve grenswaarde kan worden opgelost door aan te geven dat opleidingen bij het bereiken van een bepaalde absolute waarde altijd een positieve beoordeling krijgen, ongeacht waar ze in de verdeling van opleidingen terecht zijn gekomen (bijv. bij de onderste IO\%).

Als het gaat om de robuustheid van grenswaardes, is het duidelijk dat de arbeidsmarktperspectieven van opleidingen over de tijd veranderen onder invloed van bijvoorbeeld de conjunctuur, en daarmee ook de absolute grenswaardes van de indicatoren. Relatieve grenzen zijn minder gevoelig voor deze veranderingen. Om het probleem enigszins te ondervangen kan er bij het vaststellen van absolute grenswaardes gebruik worden gemaakt van meerjarige gemiddeldes voor de relevante indicatoren.

Samengevat wordt vastgesteld dat een absolute grens goed scoort op de criteria probleemgerichtheid en eenvoud. Het is echter de vraag of de absolute grenswaarde voldoende realistisch en robuust is, zeker in een periode van hoogconjunctuur. Een relatieve grens zal dan onderwijsinstellingen nadrukkelijker prikkelen.

\section{Correcties van grenswaardes}

Bij het vaststellen van grenswaardes voor beroepsopleidingen aan onderwijsinstellingen in het mbo kan er onder andere onderscheid worden gemaakt tussen de beroepsopleidende leerweg (bol) en de beroepsbegeleidende leerweg (bbl). De twee leerwegen leiden binnen een opleiding op tot dezelfde eindkwalificaties. Bij het samenstellen van arbeidsmarktgegevens zijn er twee keuzemogelijkheden. Of de arbeidsmarktgegevens worden voor de twee opleidingen tezamen gepresenteerd, of de bol- en bbl-opleiding worden apart beoordeeld. Dit laatste kan gebeuren door opleidingen in verschillende groepen in te delen en te beoordelen, of door statistische correcties aan te brengen in de grenswaardes waaraan opleidingen moeten voldoen.

Bij het bepalen van de grenzen kan er tevens onderscheid worden gemaakt tussen mbo-niveaus, studierichting en regio. Enerzijds is de economische situatie in de regio of de branche een verzachtende omstandigheid voor een sterk verslechterd arbeidsmarktperspectief. Anderzijds blijft het van belang om studiekiezers zoveel mogelijk te sturen naar opleidingen met minder slechte perspectieven, dat betekent naar opleidingen van een andere richting en meestal hoger niveau. Ook kunnen onderwijsinstellingen afgestudeerden stimuleren om verder te leren in plaats van te gaan werken. Een goede aansluiting tussen onderwijs en arbeidsmarkt is des te belangrijker in regio's met een slechte arbeidsmarktsituatie, onderwijsinstellingen die in deze regio's opleidingen aanbieden zouden dan ook een grotere kans moeten hebben hierop te worden aangesproken. Het is dus niet eenvoudig om te bepalen hoe en in welke mate opleidingen kunnen afwijken van het algemeen gemiddelde. 
Samengevat wordt vastgesteld dat een gecorrigeerde grenswaarde meer geschikt is voor het in kaart brengen van het probleem. Ook zijn gecorrigeerde grenswaardes realistischer dan de niet niet-gecorrigeerde, omdat beter rekening wordt gehouden met de omstandigheden. De gecorrigeerde waardes zijn echter minder eenvoudig uit te leggen en toe te passen, en minder robuust omdat ze afhankelijk zijn van hoe de correcties worden toegepast.

\section{Meer- of eenjarige waardes}

Met een meerjarig gemiddelde worden toevallige uitschieters uitgemiddeld, en kunnen bovendien meer kleine opleidingen in de analyses worden meegenomen. Het is de vraag over hoeveel jaren het meerjarig gemiddelde moet worden berekend om te corrigeren voor de conjunctuur of voor toevallige omstandigheden. Uit de analyses van het vorige hoofdstuk bleek het driejarige gemiddelde van het percentage werkzaam van het CBS beter te correleren met de overige arbeidsmarktindicatoren dan het eenjarige percentage. De ROA-gegevens over opleidingen zijn echter vaak gebaseerd op vijfjarige gemiddeldes vanwege het steekproefkarakter van de verzamelde data. In een periode van vijf jaar kunnen er structurele veranderingen in het curriculum, in het onderwijs (nieuwe opleidingen), of op de arbeidsmarkt hebben plaatsgevonden die onvoldoende worden meegenomen in een gemiddelde over vijf jaar.

In dit hoofdstuk zijn in veel gevallen driejaarsgemiddeldes gebruikt voor het percentage werkzaam, mede op basis van de beschikbaarheid van gegevens bij het CBS. Driejaarsgemiddeldes kunnen worden beschouwd als een compromis tussen enerzijds een éénjaarsmeting voor het laatste beschikbare jaar en anderzijds het hanteren van vijfjaarsgemiddelde, met andere woorden tussen actualiteit (criterium realistisch) en robuustheid. Ook de Inspectie van het Onderwijs hanteert driejaarsgemiddelde in haar toezicht op de onderwijsprestaties van scholen.

Hoe korter en recenter de waarnemingsperiode bij het vaststellen van de grenswaardes is, hoe realistischer en eenvoudiger de uitkomsten gebruikt kunnen worden. Maar meerjarige gemiddeldes geven vaak beter het probleem weer en zijn robuuster. Alvorens verder te gaan met de verschillende methodes voor de grensbepaling, wordt in de volgende paragraaf gekeken hoe dit is gebeurd bij de vsv-aanpak, en welke overwegingen daar een rol speelden.

\subsection{Case-study: de vsv-aanpak}

Wat betreft afspraken met scholen en het vaststellen van grenswaardes is er de laatste jaren veel ervaring opgedaan met het terugdringen van het aantal voortijdig schoolverlaters (vsv'ers). De vsv-aanpak kan model staan voor een aanpak gericht op het verbeteren van de arbeidsmarktrelevantie van opleidingen. Het aantal jongeren dat de school verlaat zonder startkwalificatie is in tien jaar meer dan gehalveerd: van $5,5 \%$ 
(71.000) in 2002 naar 2,I\% in 20I2-2013 (37.950). ${ }^{20}$ Het halveren van het aandeel vsv'ers tussen 2000 en 2020 was één van de Lissabon-doelstellingen, waaraan Nederland inmiddels heeft voldaan. De norm van de Lissabondoelstelling week overigens af van de eigen Nederlandse norm, zowel wat betreft de definitie van vsv'ers (totaal aantal versus alleen nieuwe vsv'ers in Nederland) als ook de maatstaf als zodanig (procentueel versus reductie in aantal in Nederland).

Voor dit rapport is het vooral van belang hoe de grenswaardes zijn vastgesteld in de vsv-aanpak, en met welke beleidsmaatregelen dit gepaard is gegaan. In de brief van de minister (Ministerie van OCW, 20I3b) wordt opgemerkt dat tot 2012 de reductie in aantallen voortijdig schoolverlaters voorop stond, terwijl daarna procentuele normen als grenswaardes zijn gehanteerd. Het argument dat hiervoor wordt genoemd, is dat scholen in aantal leerlingen kunnen krimpen of groeien, en dat een procentuele norm (van het aantal leerlingen) ook de scholen beloont die de afgelopen jaren de uitval al flink hebben teruggedrongen en op een laag uitvalpercentage zijn uitgekomen. Verder houdt de minister rekening met verschillen tussen sectoren en opleidingsniveaus, en gelden er verschillende normen voor het vo en het mbo. Scholen die onder de afgesproken streefnorm zakken ontvangen een prestatiesubsidie. De normen zijn vanaf 2012 ook opgenomen in het Toezichtkader van de Inspectie van het Onderwijs. Mogelijke afwijkingen van de norm die zouden kunnen ontstaan door allerhande beleidsontwikkelingen (zoals bezuinigingen op jeugdzorg, wijzigingen in de sociale zekerheid, invoering passend onderwijs, invoering entreeopleiding en hogere eisen taal en rekenen), zullen apart worden onderzocht.

De vsv-aanpak kenmerkt zich door een gezamenlijke, integrale aanpak van verschillende partijen, dat wil zeggen niet alleen scholen uit het middelbaar beroepsonderwijs en voortgezet onderwijs, maar ook het Rijk, gemeentes, bedrijfsleven en jeugdinstellingen. ${ }^{21}$ Voor de aanpak zijn er 39 RMC-regio’s (Regionale Meld- en Coördinatiefunctie) opgericht. Het is volgens de minister belangrijk het aantal vsv'ers terug te dringen, omdat voortijdig schoolverlaten samenhangt met (wellicht zelfs deels een oorzaak is van) werkloosheid, slechte gezondheid, criminaliteit, etc. De vsv-problematiek onder jongeren wordt als een meervoudige problematiek gezien, gerelateerd aan onder meer ontduiking van de leerplicht, drugsgebruik en criminaliteit. In Amsterdam zijn er bijvoorbeeld verschillende partijen betrokken in de vsv-aanpak (Bureau Leerplicht Plus, Openbaar ministerie, Bureau jeugdzorg, Politie en GGD). De vsv-problematiek is niet alleen gerelateerd aan de leerplicht (tot I6 jaar), maar ook aan de nieuwe ingevoerde kwalificatieplicht (tot I8 jaar). Er is bovendien een aparte aanpak voor I8+ voortijdig schoolverlaters, waarbij de Regionaal Meld- en Coördinatiepunten (RMC's) de vsv'ers van 18 tot 23 jaar begeleiden.

20. Ministerie van OCW (20I4).

2I. Het navolgende komt uit de brief van de minister van OCW aan de Tweede Kamer (Ministerie van OCW, 2013b). 
De minister schrijft de bereikte daling van het aantal vsv'ers in Nederland toe aan de gezamenlijke, integrale aanpak van alle partijen, en aan de diverse maatregelen die zijn genomen: prestatieafspraken vastgelegd in regionale convenanten, invoering van de kwalificatieplicht en plusvoorzieningen, betere registratie van schoolverzuim, betere studiekeuze- en loopbaanbegeleiding en transparantie in de cijfers. ${ }^{22}$ De grote daling in het laatste jaar (ruim 8.000 vsv'ers) is voor ongeveer de helft toe te schrijven aan de aangescherpte meetmethode, waardoor eerder onterecht getelde vsv'ers niet meer worden geteld. De registratie was dus voor een aanzienlijk deel van de vsv'ers niet adequaat waardoor de vsv-problematiek (bij sommige opleidingen en scholen of regio's) groter leek dan hij feitelijk was. Een belangrijk neveneffect van de vsvinspanningen is dan ook dat er veel beter zicht is ontstaan op de problematiek van het voortijdig schoolverlaten, dat wil zeggen zowel de oorzaken van uitval als de omstandigheden van vsv'ers en de registratie. Nieuwe maatregelen om het aantal vsv'ers terug te dringen zijn prestatiesubsidies voor individuele instellingen en programmasubsidies voor een gezamenlijke regionale aanpak.

De vsv-aanpak ging in essentie uit van landelijke kwantitatieve doelen (streefwaardes), die in kwantitatieve aantallen naar instellingen werden vertaald. Deze instellingen moesten volgens afspraak het aantal vsv'ers terugdringen, waarbij tevens transparantie werd gevraagd, flankerend beleid (zie hierboven) werd gevoerd, en bovendien ondersteuning werd geboden door accountmanagers. Gezien de daling van het aantal vsv'ers waren de grenswaardes waaraan instellingen moesten voldoen waarschijnlijk probleemgericht en realistisch. Hoewel het niet op voorhand duidelijk was wie voortijdig schoolverlater is en wie niet (mede door definitie- en registratieproblemen) kan toch gesteld worden dat de gebruikte grenswaardes tevens eenvoudig te gebruiken waren. Wat betreft de robuustheid, zijn in de loop der tijd de absolute grenswaardes telkens aangepast om onderwijsinstellingen te prikkelen het aantal vsv'ers telkens verder terug te dringen.

Het is tot slot van belang op te merken dat er belangrijke verschillen zijn tussen de vsv-aanpak en de problematiek rondom de arbeidsmarktrelevantie van opleidingen, als onderdeel van de macrodoelmatigheid. Macrodoelmatigheid houdt qua aard meer verband met het stelsel van opleidingen in plaats van met het gedrag van jongeren die niet de vereiste startkwalificatie halen. Het bemachtigen van een baan (op niveau) van een schoolverlater speelt zich bovendien per definitie wat meer af buiten de macht van scholen, omdat men hier meer afhankelijk is werkgevers en de situatie op de arbeidsmarkt. Anderzijds is de vsv-problematiek wellicht ingewikkelder door de samenhang met allerlei andere factoren zoals de gezinssituatie en sociale achtergrond van leerlingen, terwijl het opleidingenaanbod van scholen direct is te beïnvloeden.

22. Zie voor een recent overzicht van alle maatregelen: http://www.rijksoverheid.nl/onderwerpen/aanvalop-schooluitval/aanpak-voortijdig-schoolverlaten 


\subsection{Grenswaardes voor de indicator percentage werkzaam}

In de volgende drie subparagrafen worden achtereenvolgens drie methoden uitgewerkt om te komen tot een grenswaarde voor het percentage werkzaam. Het gaat hierbij om:

- Methode I - Absolute grensbepaling;

- Methode 2 - Relatieve grensbepaling zonder correcties;

- Methode 3 - Relatieve grensbepaling met correcties.

\subsubsection{Methode 1 - Absolute grensbepaling}

Om te beginnen leiden we min of meer intuïtief het percentage werkzaam onder schoolverlaters af op basis van algemeen beschikbare gegevens over de Nederlandse arbeidsmarkt. Daartoe kan men de volgende redenering hanteren. Vrij algemeen wordt een werkloosheidspercentage van $5 \%$ als een 'natuurlijk' percentage gezien voor de beroepsbevolking. Omgerekend naar jongeren van I5-24 jaar, dit is de brede leeftijdscategorie van schoolverlaters, zou het percentage dubbel zo hoog zijn, dus Io\%. Als we uitsluitend willen kijken naar de arbeidsparticipatie van schoolverlaters, dat wil zeggen de jongeren die geen onderwijs meer volgen, kunnen we een vergelijking maken met de 25- tot 34-jarigen, die vrijwel allemaal uit het onderwijs zijn gestroomd. De bruto participatiegraad ${ }^{23}$ voor deze leeftijdscategorie is $90 \%$, en kan als uitgangspunt dienen ${ }^{24}$ voor de 15 - tot 24 -jarigen die geen onderwijs volgen, i.e. de schoolverlaters. Hieruit volgt, in combinatie met het werkloosheidspercentage van Io\% onder jongeren, een percentage werkzaam van $8 \mathrm{I} \%(=90 \%-(0, \mathrm{IO} \times 90 \%)$. Dit betekent dat een percentage werkzaam van $8 \mathrm{I} \%$ onder schoolverlaters volgt uit een natuurlijk werkloosheidspercentage van $5 \%$ in de beroepsbevolking.

Bij een algemeen werkloosheidspercentage van $8 \%$, in tijden van laagconjunctuur, zou het werkloosheidspercentage voor jongeren uitkomen op I6\%. Zonder ontmoedigingseffect ('discouraged worker effect') ${ }^{25}$ blijft de bruto participatiegraad op $90 \%$ voor de niet-onderwijsvolgende jongeren van I5-24 jaar (i.e. de schoolverlaters), maar daalt het percentage werkzaam naar $75,6 \%(=90 \%-(0,16 \times 90 \%))$. Een verdubbeling van de werkloosheid onder schoolverlaters van 8 naar I6\% leidt derhalve in dit gestileerde voorbeeld tot een daling van het percentage werkzaam van $81 \%$ naar ca. $76 \%$. De exacte empirische relaties zijn echter moeilijk te schatten, en kunnen variëren per geslacht, leeftijdscategorie, etniciteit, opleidingsniveau, regio en ook periode. In deze

23. De bruto participatiegraad is de som van degenen die werken en werkloos zijn als percentage van de bevolking in de desbetreffende leeftijdscategorie. Bij de netto participatiegraad gaat het alleen om de werkenden als percentage van de bevolking, en dit percentage is voor de jongeren in de beroepsbevolking te vergelijken met het percentage werkzaam onder schoolverlaters.

24. Dit percentage is in werkelijkheid wat lager, namelijk ca. $88 \%$ in hoogconjunctuur voor de leeftijdscategorie 25-34 jaar (bron CBS/EBB van CBS Statline).

25. Er zijn echter aanwijzingen dat een hoger werkloosheidspercentage onder mbo'ers samenhangt met een hogere onderwijsdeelname van jongeren in het mbo. Zie CPB (2OII). 
paragraaf wordt aan de hand van arbeidsmarktgegevens van Statline van het CBS nagegaan welke percentages als grenswaarde kunnen gelden voor de arbeidsdeelname van schoolverlaters.

In tabel 4.I wordt de hierboven gevolgde redenering geillustreerd aan de hand van werkelijke arbeidsmarktgegevens van de gehele beroepsbevolking. Het percentage werkzaam voor de 25-34 jarigen blijkt wat lager te zijn dan uit het hierboven weergegeven voorbeeld voor deze leeftijdscategorie kan worden afgeleid $(85,5 \%=90 \%-(0,05$ x $90 \%$ ), en de laatste jaren terug te vallen naar $80 \%$. Het percentage werkloos voor de $15-24$ jarigen is inderdaad grofweg twee keer zo hoog als voor de hele beroepsbevolking, en blijkt in de beschouwde periode naar I6\% te stijgen. Het percentage werkzaam voor deze groep heeft voor de schoolverlaters weinig betekenis omdat er in tabel 4.I is gepercenteerd op de totale leeftijdsgroep, inclusief de onderwijsvolgenden.

\section{Tabel 4.1}

Percentage werkzaam (netto arbeidsparticipatie) en percentage werkloos voor de beroepsbevolking naar leeftijdscategorie, 2001-2013

\begin{tabular}{|lccccccc|} 
& & & \% Werkzaam & \multicolumn{3}{c}{ \% Werkloos } \\
\hline Periode & $15-64$ jr. & $15-24$ jr. & $25-34$ jr. & $15-64$ jr. & $15-24$ jr. & $25-34$ jr. \\
\hline 2001 & $\%$ & $\%$ & $\%$ & $\%$ & $\%$ & $\%$ \\
\hline 2002 & 64.2 & 45.1 & 81.3 & 3.5 & 7.4 & 3.0 \\
\hline 2003 & 64.5 & 44.3 & 80.5 & 4.1 & 8.5 & 3.9 \\
\hline 2004 & 63.9 & 42.1 & 79.8 & 5.4 & 10.6 & 5.3 \\
\hline 2005 & 63.5 & 39.6 & 79.9 & 6.4 & 13.2 & 6.0 \\
\hline 2006 & 63.7 & 38.6 & 80.5 & 6.5 & 12.6 & 5.9 \\
\hline 2007 & 64.8 & 39.2 & 82.3 & 5.5 & 10.4 & 4.6 \\
\hline 2008 & 66.6 & 41.1 & 84.0 & 4.5 & 9.2 & 3.4 \\
\hline 2009 & 68.2 & 42.1 & 85.4 & 3.8 & 8.4 & 3.1 \\
\hline 2010 & 67.8 & 40.2 & 84.3 & 4.8 & 11.0 & 4.5 \\
\hline 2011 & 67.1 & 37.7 & 83.5 & 5.4 & 11.7 & 5.0 \\
\hline 2012 & 67.2 & 38.0 & 82.4 & 5.4 & 9.8 & 5.5 \\
\hline 2013 & 67.2 & 37.2 & 81.6 & 6.4 & 12.6 & 6.5 \\
\hline Bron: CBS/EBB & 66.1 & 35.6 & 79.1 & 8.3 & 15.9 & 8.2 \\
\hline
\end{tabular}

In figuur 4.I is aan de hand van administratieve gegevens van het CBS het percentage werkzaam weergegeven voor jongeren tussen 15 en 27 jaar die geen onderwijs meer volgen. Dat is het belangrijkste verschil met het percentage werkzaam van $15-24$ jr. in tabel 4.I. Andere verschillen zijn dat er in tabel 4.I gebruikt is gemaakt van de Enquête Beroepsbevolking (EBB) als databron, en van de definitie van de beroepsbevolking (werkzaam voor minimaal I2 uur per week). Bij het percentage werkzaam in figuur 4.I is geen norm van I2 uur werk per week van toepassing. In plaats daarvan zijn alleen die jongeren als werkzaam geteld die volgens de administratieve bestanden geen uitkering ontvangen. Het percentage werkzaam is tussen 2005 en 2008 gestegen met ruim 
$2 \%$-punt tot $77 \%$, maar daarna door de economische crisis teruggevallen tot ca. $73 \%$. Deze percentages liggen duidelijk wat lager dan de percentages die uit het gestileerde voorbeeld naar voren kwamen (8I en 76\%).

\section{Figuur 4.1}

Percentage werkzaam zonder uitkering, jongeren 15-27 jaar die niet-onderwijsvolgend zijn, 20052011

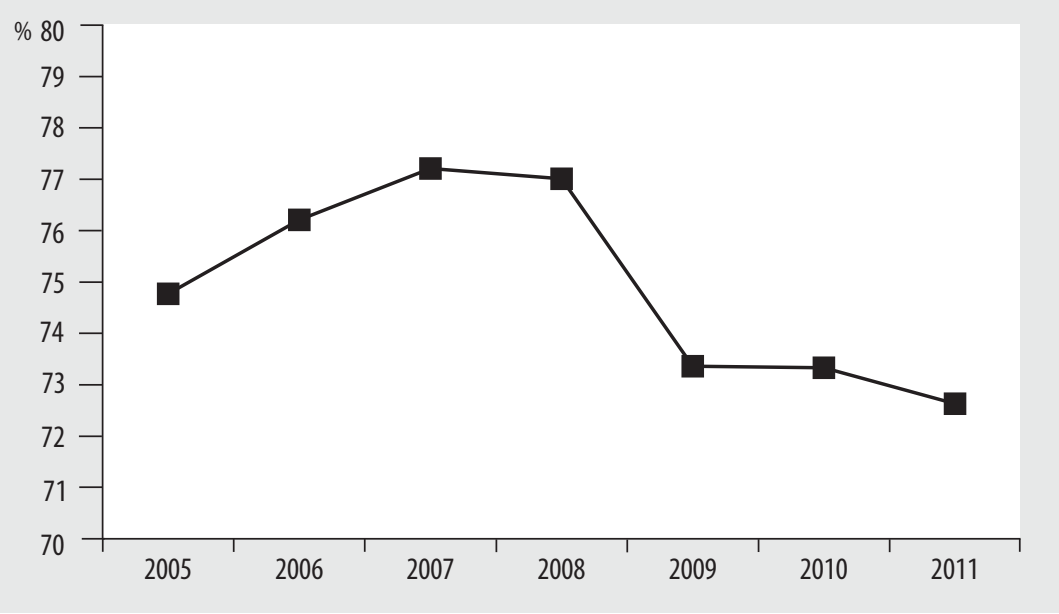

Bron: $\mathrm{CBS} / \mathrm{SSB}$

In figuur 4.2 is er alleen gekeken naar de niet-onderwijsvolgenden van I5-24 jr. met een opleiding op middelbaar niveau (minimaal startkwalificatie). Het blijkt dat percentage werkzaam en percentage werkloos sterk negatief gecorreleerd zijn over de tijd. Uit de figuur kan worden afgeleid dat in min of meer conjunctuurneutrale jaren de lijnen voor beide percentages elkaar snijden in de figuur. Dat is bij ongeveer $85 \%$ werkzaam en $6,5 \%$ werkloos. In slechte jaren daalt het percentage werkzaam richting $80 \%$, maar blijft het boven de $8 \mathrm{I}$ à $82 \%$. Deze percentages werkzaam liggen hoger dan die uit het gestileerde voorbeeld aan het begin van de paragraaf en de percentages uit figuur 4.I. Een belangrijke verklaring hiervoor is dat het in figuur 4.2 alleen schoolverlaters (niet-onderwijsvolgenden) betreft van middelbaar niveau, terwijl het eerder om alle schoolverlaters ging (dus incl. degenen van lager niveau). 


\section{Figuur 4.2}

Percentage werkzaam (linkeras) en percentage werkloos (rechteras) voor niet-onderwijsvolgenden, 15-24 jaar, met diploma op middelbaar niveau (mbo 2-4, havo/vwo), 2002-2012

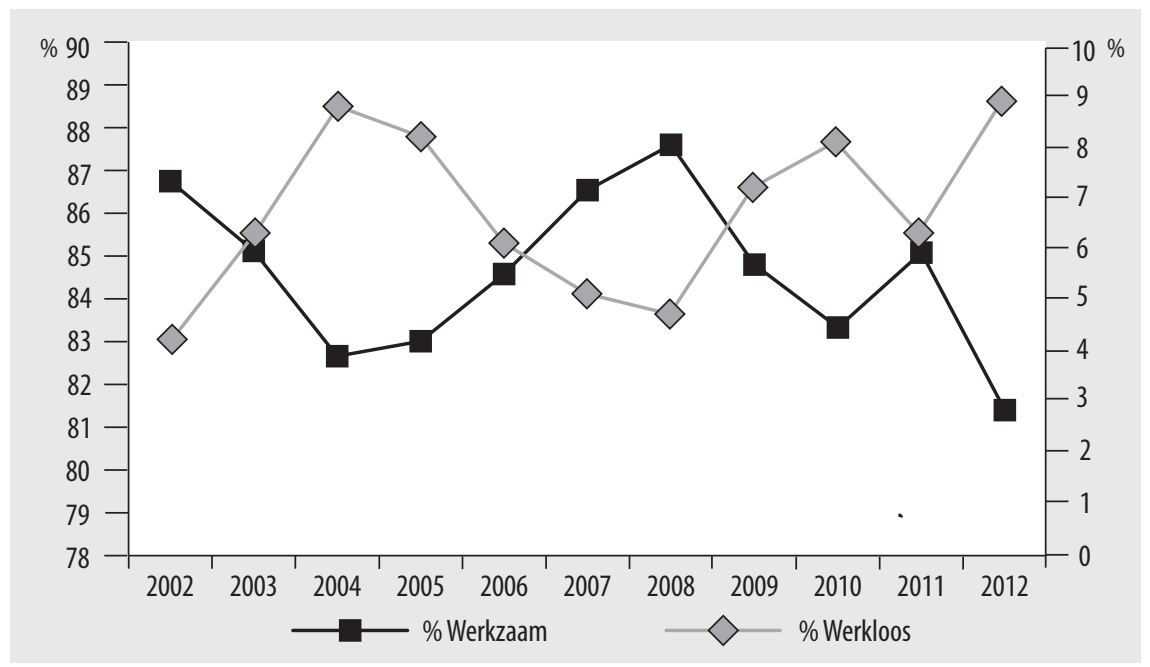

Bron: CBS/EBB

Het blijft echter moeilijk om de hiervoor gepresenteerde gegevens te relateren aan de populatie van scholen die beoordeeld moeten worden op de daarvoor beschikbare en geschikt geachte indicatoren, in dit rapport het percentage werkzaam. De relaties tussen een externe arbeidsmarktindicator en dit percentage is verre van evident, en bovendien is het erg moeilijk om rekening te houden met verschillen in definities van indicatoren, en met verschillen in kenmerken van opleidingen, mede door een te korte tijdsperiode om empirische relaties te schatten. De indicatoren voor scholen gaan over schoolverlaters een bepaalde periode na afstuderen, waarbij er voor een deel van de opleidingen geen arbeidsmarktinformatie beschikbaar is. Bij externe arbeidsmarktindicatoren wordt bijna altijd gekeken naar een deel van de beroepsbevolking, waarbij het door databeperkingen vaak lastig is om te differentiëren naar leeftijdscategorie of -cohort, en leerweg of niveau.

Tot slot resteert de vraag of er een absolute grenswaarde valt af te leiden uit de hier weergegeven externe arbeidsmarktgegevens. Heel rudimentair zou men kunnen stellen dat een gemiddelde van $80 \%$ werkzaam voor mbo-schoolverlaters, zelfs in slechte economische tijden, haalbaar moet zijn. Dat betekent echter dat grofweg de helft van de mbo-opleidingen hieraan voldoet (als de mediaan en het gemiddelde aan elkaar gelijk zijn), en de andere helft niet. Een percentage werkzaam van $80 \%$ lijkt daarmee erg hoog als grenswaarde voor individuele opleidingen, maar zou wel als een streefwaarde kunnen gelden voor de onderwijsinstellingen. Dit sluit aan bij de onderwijspraktijk (van de Inspectie van het Onderwijs), waarbij men er impliciet van uitgaat dat het gemiddelde haalbaar moet zijn voor alle opleidingen. 


\subsubsection{Methode 2 - Relatieve grensbepaling zonder correcties}

In deze paragraaf wordt een nadere uitwerking gegeven van de afleiding van een relatieve grenswaarde voor het percentage werkzaam. 'Relatief' wil hier zeggen dat een opleiding wordt afgezet tegen andere opleidingen. Er wordt op zowel landelijk als regionaal niveau gekeken naar de verdeling van opleidingen wat betreft het percentage werkzaam. Voor het percentage werkzaam waren er bij het schrijven van dit rapport slechts beperkt gegevens over de afzonderlijke jaren beschikbaar (maximaal 3 jaar). Daarom is er als alternatieve indicator voor arbeidsdeelname ook gekeken naar het werkloosheidspercentage over meerdere jaren, dat sterk correleert met het percentage werkzaam (zie de vorige subparagraaf en hoofdstuk 3). Voor het werkloosheidspercentage waren op landelijk niveau wel gegevens voor voldoende verschillende jaren beschikbaar.

Bij de vraag hoe de relatieve grenzen kunnen worden bepaald, speelt de statistische verdeling van de waardes over de verschillende opleidingen een rol. In eerste instantie wordt gedacht aan het oormerken van IO\% van de beroepsopleidingen met het laagste percentage werkzaam (of het hoogste percentage onderbenutting, zie de volgende paragraaf). De grens van IO\% is een praktische norm, die ook door de Inspectie van het Onderwijs wordt gehanteerd bij de beoordeling van de kwaliteit van scholen. Een andere mogelijkheid kan zijn om te oormerken op basis van het aantal standaard deviaties (één of twee) dat wordt afgeweken van het gemiddelde. Nader onderzoek naar de verdeling van de waardes zou moeten uitwijzen wat de voorkeur heeft. Op voorhand kan gesteld worden dat de standaard deviatie het nadeel heeft dat niet alleen de rangorde van opleidingen als zodanig, maar ook de spreiding van alle opleidingen wat betreft de scores op de arbeidsmarktindicatoren (percentage werkzaam of onderbenutting) van invloed is op waar de grens getrokken wordt. Dat betekent voor onderwijsinstellingen dat er een extra onzekere factor is als zij boven de grenswaarde willen blijven.

\section{Percentage werkzaam: landelijke gegevens}

Onderstaande analysen zijn gemaakt op basis van gegevens aangeleverd door het CBS waarbij - mits de drie niveaus afzonderlijk van elkaar worden bekeken - 3I4 beroepsopleidingen onderscheiden kunnen worden. De opleidingen die over de drie jaren gemiddeld (2008, 2009, 20I0) minder dan 20 schoolverlaters afleverden zijn in deze analyses buiten beschouwing gelaten. Dit in eerste instantie om een grotere vergelijkbaarheid met de presentatie van de schoolverlatersgegevens van het ROA te bewerkstelligen. ${ }^{26}$ In figuur 4.3 is te zien hoe het percentage werkzaam (landelijk, I jaar na afstuderen, minimaal I2 uur per week werkzaam, 2009-20II) verdeeld is over 249

26. Merk echter op dat bij het aantal van 20 de doorstromers niet zijn inbegrepen bij het CBS, maar wel bij het ROA. Een ander verschil is dat het bij het ROA alleen respondenten van een enquête betreft, bij het CBS gaat het om alle schoolverlaters die niet meer in het bekostigd onderwijs als deelnemers ingeschreven staan. 
beroepsopleidingen. Evenals in hoofdstuk 3 wordt hierbij geen onderscheid gemaakt tussen bol en bbl. Dit laatste vanuit de veronderstelling dat het gemiddelde voor elke leerweg haalbaar moet zijn.

Uit figuur 4.3 blijkt dat de IO\%-grens van de slechtst scorende opleidingen ligt bij $72 \%$ werkzaam. Met andere woorden, bij het $\mathrm{IO}^{\mathrm{e}}$ percentiel van de beroepsopleidingen is $72 \%$ van de schoolverlaters aan het werk voor I2 uur of meer per week. De cumulatieve verdeling van de figuur laat zien dat het laagste percentage $56 \%$ is, en het hoogste IO०\%. Er is een grote spreiding aan de onderkant (tussen 56 en $72 \%$ werkzaam), en vervolgens neemt het aantal opleidingen met een hoger percentage snel toe, met name voorbij $75 \%$ werkzaam. De mediaan ligt bij $88 \%$ werkzaam, het gemiddelde bij $86 \%$. Dat is wat hoger dan het gemiddelde bij de absolute grensbepaling uit de vorige subparagraaf, die vooral is gebaseerd op de gegevens van figuur 4.2. Voor de jaren 2009 , 2010 en $201 \mathrm{I}$ is het gemiddelde in deze figuur ruim $84 \%$. Bij het stellen van een absolute grens van minimaal $72 \%$ werkend krijgt ca. IO\% van de opleidingen een negatieve beoordeling voor de arbeidsmarktrelevantie. Bij een absolute grens van minimaal 68\% zijn er $5 \%$ slecht scorende opleidingen met een negatieve beoordeling. Zoals hierna zal blijken kunnen deze grenzen echter flink schuiven over de tijd, afhankelijk van onder meer de economische situatie.

\section{Figuur 4.3}

Cumulatieve verdeling van ca. 250 beroepsopleidingen naar percentage werkzaam 1 jaar na afstuderen, gemiddelde 2009-2011

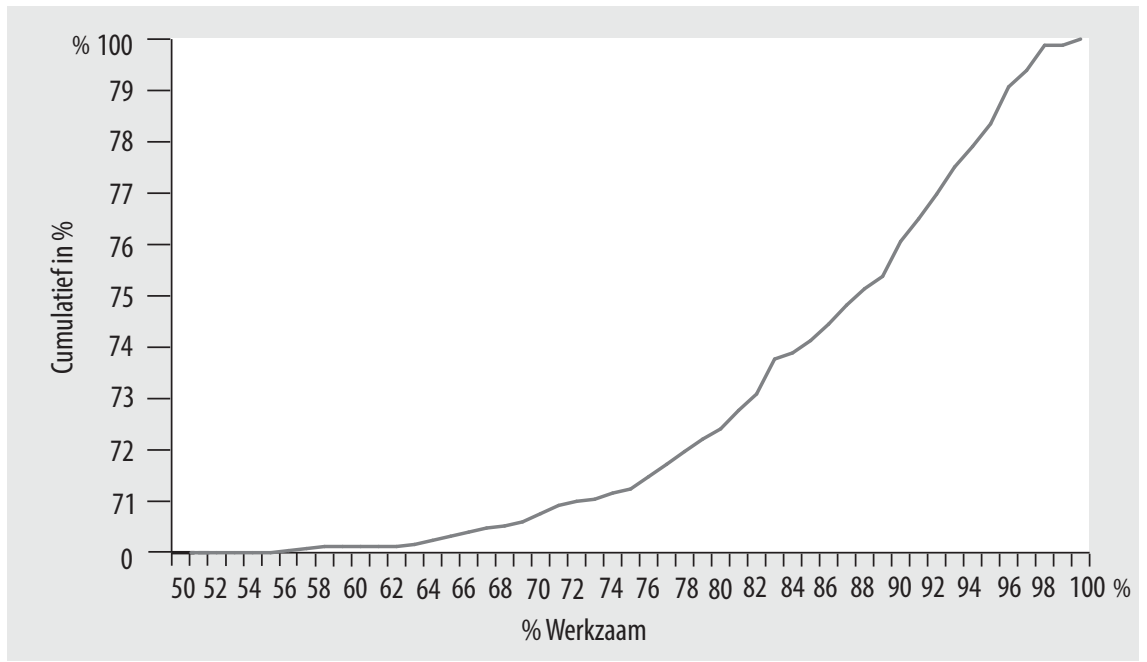

Bron: $\mathrm{CBS} / \mathrm{SSB}$

Om meer gevoel voor relatieve grensbepalingen met het percentage werkzaam te krijgen is in figuur 4.4 tevens het werkloosheidspercentage onder schoolverlaters in een cumulatieve verdeling weergegeven. Uit hoofdstuk 3 is immers gebleken dat deze 
twee indicatoren sterk met elkaar gecorreleerd zijn. In deze figuur neemt het werkloosheidspercentage af van links naar rechts om beter te kunnen vergelijken met de vorige figuur. Ook hier is er een grote spreiding van opleidingen die slecht scoren, dat wil zeggen een hoge werkloosheid hebben. Als het gaat om de IO\% van de slechtst scorende opleidingen (het $\mathrm{IO}^{\mathrm{e}}$ percentiel), ligt de grens bij $20 \%$ werkloosheid. Voor het $20^{\mathrm{e}}$ percentiel ligt de grens bij IO\%. Voor de beter scorende opleidingen wordt de werkloosheid snel lager.

\section{Figuur 4.4}

Cumulatieve verdeling van ca. 100 beroepsopleidingen naar werkloosheidspercentage 1,5 jaar na afstuderen, gemiddelde 2007-2011

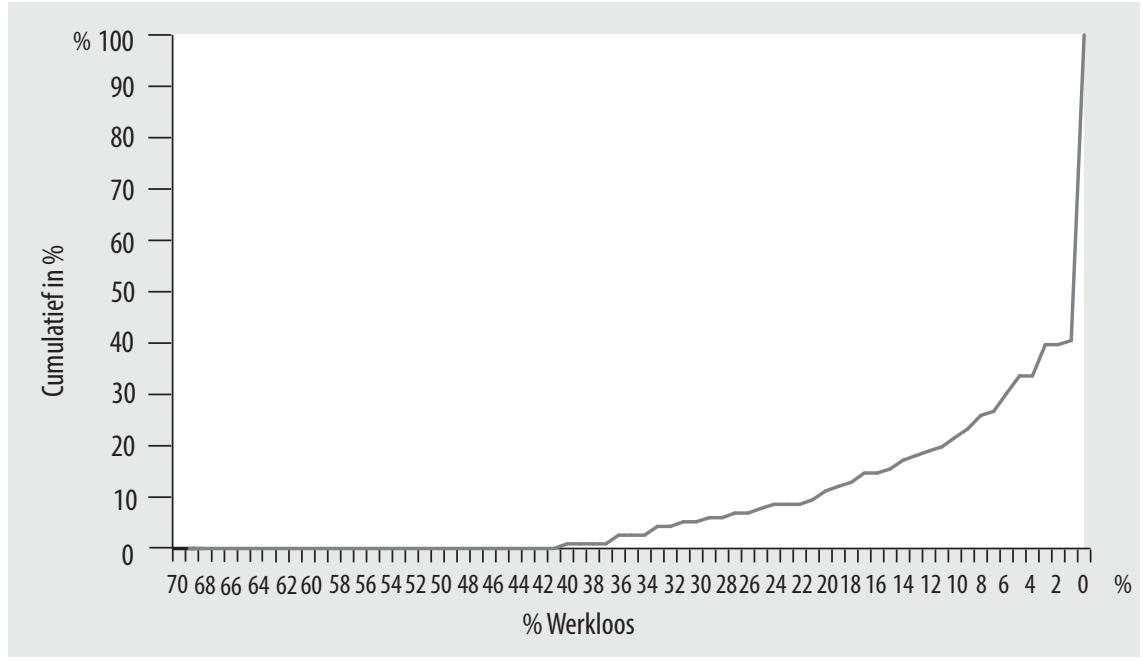

Bron: ROA/SIS

Om te corrigeren voor conjuncturele ontwikkelingen ligt het voor de hand om uit te gaan van een meerjarig gemiddelde. Onderstaande laat zien wat de gevolgen kunnen zijn als dit niet wordt gedaan. In figuur 4.5 zijn de werkloosheidspercentages voor de verschillende percentielen weergegeven over de tijd. Duidelijk is dat 2007 en 2008 de betere jaren voor schoolverlaters zijn. Dit zijn de jaren voor dat de economische crisis de arbeidsmarkt voor schoolverlaters in zijn greep kreeg. In het Ie, se, Ioe en $20^{\mathrm{e}}$ percentiel is de werkloosheid grofweg twee keer zo hoog voor de slechte jaren ten opzichte van de goede jaren. Bovendien blijkt dat ook in de slechte jaren voor meer dan $60 \%$ van de opleidingen de werkloosheid lager dan $5 \%$ is. Immers, bij het $40^{\mathrm{e}}$ percentiel is de werkloosheid lager dan $5 \%$ voor alle afzonderlijke jaren. ${ }^{27}$ In de slechte jaren loopt echter vooral bij de in de verdeling slechtst scorende opleidingen de werkloosheid flink op. Als er een absolute grenswaarde van $20 \%$ werkloosheid zou gelden voor opleidingen, dan zou in 2008 en 2009 maximaal I\% van de opleidingen

27. Bedenk echter dat dit landelijke percentages zijn, en dat geselecteerd is op opleidingen waarvoor voldoende betrouwbare arbeidsmarktgegevens beschikbaar zijn. 
deze grenswaarde niet halen. In de jaren erna zou dat echter ongeveer IO\% van de opleidingen zijn. Hieruit blijkt dat het vaststellen van dezelfde absolute grenswaarde voor meerdere achtereenvolgende jaren van het ene op het andere jaar grote gevolgen kan hebben voor het aandeel van de opleidingen dat de grenswaarde niet haalt.

\section{Figuur 4.5}

Verdeling naar percentielen van het werkloosheidspercentage onder schoolverlaters, 2007-2011

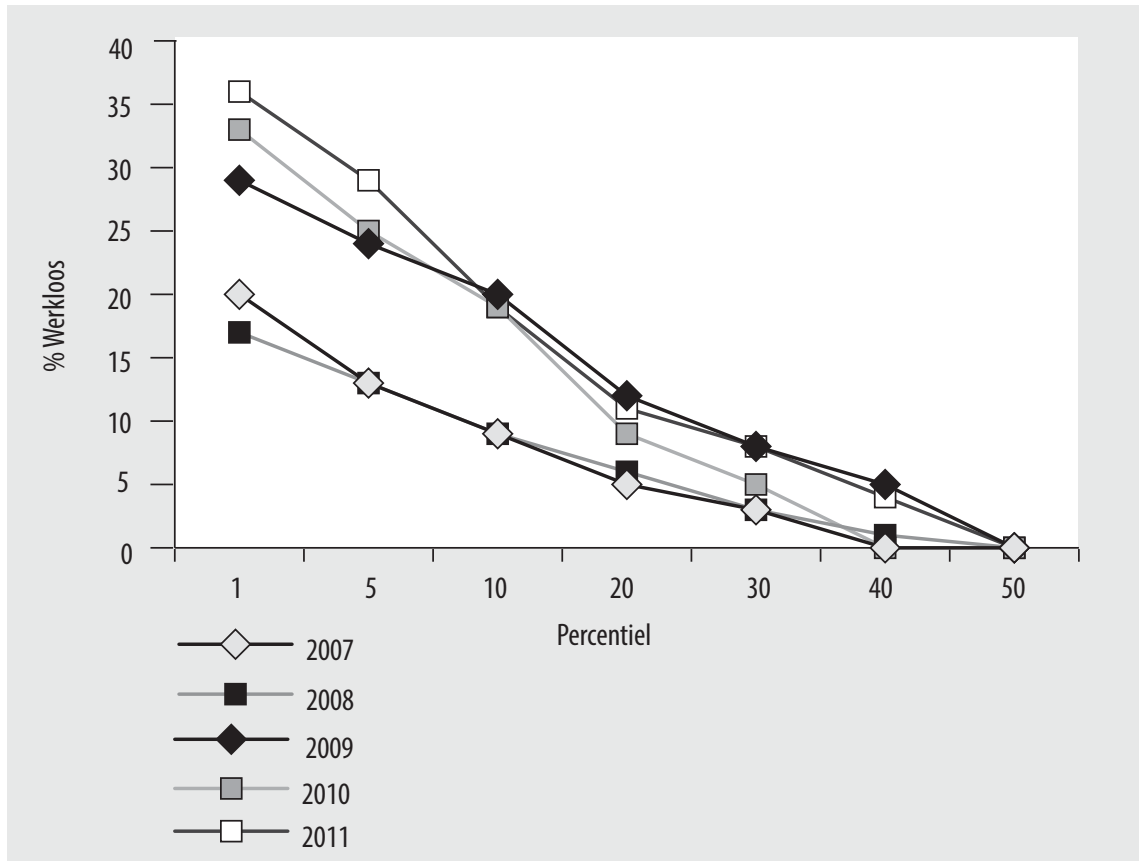

Bron: ROA/SIS

\section{Percentage werkzaam: regionale gegevens}

Bij de analyse van het percentage werkzaam per regio worden alle beroepsopleidingen (i.e. clusters van verwante opleidingen volgens de koppeltabel) van niveau 2, 3 en 4 in de verschillende regio's bekeken, waarbij bol en bbl als aparte opleidingen zijn opgenomen. Ook is er een ondergrens van gemiddeld vijf schoolverlaters in plaats van 20 schoolverlaters gebruikt, zoals bij de analyse op landelijk niveau. Hierdoor zijn er veel kleine en/of nieuwe opleidingen opgenomen in de verdeling. Bij het hanteren van de publicatiegrens van vijf schoolverlaters door het CBS speelt de privacy de belangrijkste rol: het gaat erom dat de gegevens in de bestanden niet herleid kunnen worden 
tot individuen. Vanaf vijf schoolverlaters van een opleiding in een regio, gemiddeld over de jaren 2009, 2010 en 20II, worden de gegevens wel weergegeven. ${ }^{28}$

De verdeling die in figuur 4.6 wordt weergegeven zal waarschijnlijk veel meer lijken op de verdeling op instellingsniveau dan de verdeling van figuur 4.3, waarin gebruik werd gemaakt van een selectie van grote opleidingen waarvoor landelijke CBS-gegevens bekend zijn. Uit figuur $4.3 \mathrm{kwam}$ een absolute grenswaarde van $72 \%$ werkzaam naar voren, die hoort bij een relatieve grens van het onderste ${ }^{\circ}{ }^{e}$ percentiel van de ca. 250 beroepsopleidingen die in de landelijke verdeling werden meegenomen. Voor de handhaving is echter de verdeling van de ruim 2.400 opleidingen in de verschillende regio's, zoals weergegeven in figuur 4.6, van groter belang, omdat immers individuele onderwijsinstellingen (AOC's, ROC's en vakinstellingen) moeten worden aangesproken op de opleidingen die zij aanbieden. Het percentage werkzaam van een regio is gebaseerd op de woonplaats van de schoolverlaters, en in sommige regio's valt dit percentage grotendeels samen met de schoolverlaters van één opleiding in de regio. In andere regio's zijn er meer onderwijsinstellingen die de mbo-opleiding aanbieden, of zijn de schoolverlaters van een AOC, ROC of vakinstelling in meer dan één regio woonachtig.

Uit figuur 4.6 blijkt dat er vanaf $36 \%$ werkzaam een vrij lange staart van opleidingen is tot het $5^{\mathrm{e}}$ à $\mathrm{IO}^{\mathrm{e}}$ percentiel. Ongeveer $15 \%$ van de opleidingen valt onder de grens van $72 \%$, tegenover slechts IO\% van de opleidingen in figuur 4.3 . Bij de opleidingen in het $\mathrm{IO}^{\mathrm{e}}$ percentiel in figuur 4.6 is ca. $67 \%$ van de schoolverlaters werkzaam. Bij het hanteren van het $10^{\mathrm{e}}$ percentiel als relatieve grens, hoort dus een percentielscore van $67 \%$, die tevens als absolute grenswaarde opgelegd kan worden. Dit percentage van $67 \% \mathrm{zal}$ in het vervolg als de relevante grenswaarde worden aangemerkt. Dit is lager dan het gemiddelde van $80 \%$, welke bij methode I naar voren kwam als een grens- of streefwaarde voor opleidingen. Bijna $30 \%$ van de opleidingen voldoet echter niet aan de grenswaarde van $80 \%$. De mediaan in figuur 4.6 ligt bij $90 \%$ werkzaam, hetgeen wil zeggen dat bij de helft van de opleidingen ten minste $90 \%$ van de schoolverlaters I2 uur of meer per week werkt. Dit is iets hoger dan de $88 \%$ voor de mediaan van de ca. 250 opleidingen in figuur $4 \cdot 3$.

28. Het CBS publiceert op verschillende aggregatieniveaus, zowel landelijk als regionaal als op instellingsniveau, en al dan niet gedifferentieerd naar leerweg. In deze paragraaf zijn CBS-gegevens gebruikt waarbij opleidingen zijn geaggregeerd naar regio, maar wel uitgesplitst naar leerweg. Dit levert meer 'opleidingen' op dan voor de combinatie niet uitsplitsen naar leerweg en wel naar instelling per regio. Maar als gevolg daarvan zijn er ook meer opleidingen waarvoor geen percentage werkzaam beschikbaar is op basis van de gehanteerde ondergrenzen. 


\section{Figuur 4.6}

Cumulatieve verdeling van 2.431 beroepsopleidingen geclusterd per regio, percentage werkzaam 1 jaar na afstuderen, gemiddelde 2009-2011

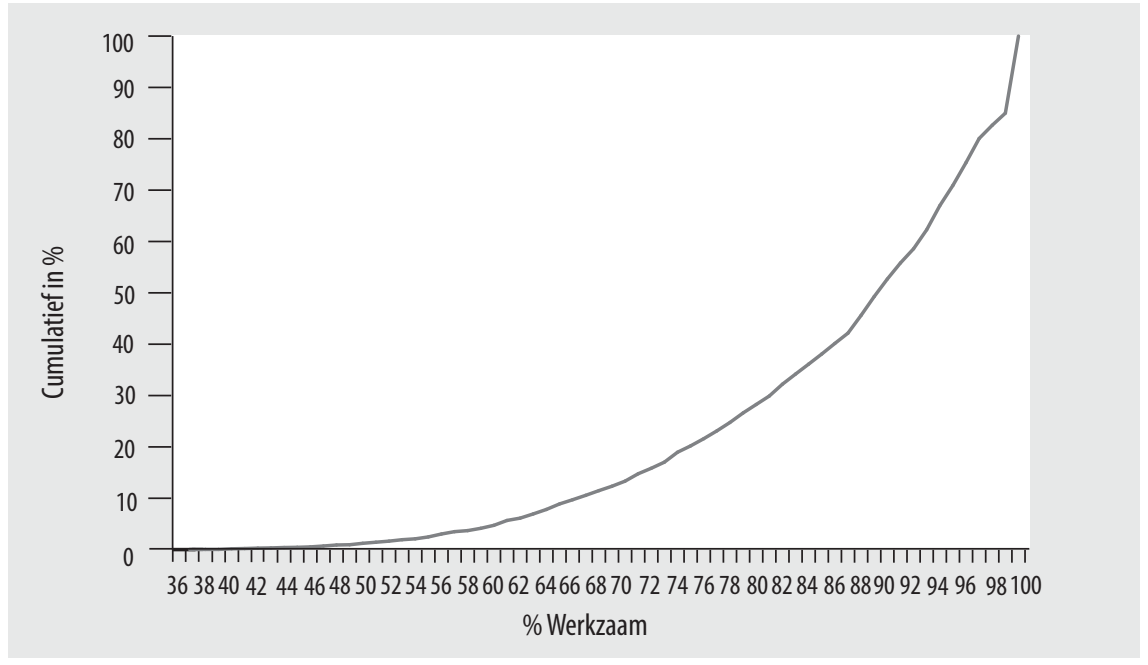

Bron: $\mathrm{CBS} / \mathrm{SSB}$

\subsubsection{Methode 3 - Relatieve grensbepaling met correcties}

In deze paragraaf wordt een derde methode uiteengezet waarbij voor de vaststelling of een opleiding onder de relatieve grens valt enkele correcties worden gemaakt. Bij het beoordelen van opleidingen zal er in dit rapport zowel gekeken worden naar de feitelijke score voor het percentage werkzaam, als naar de score die behaald wordt na correctie voor enkele kenmerken van opleiding. De factoren waarvoor bij het percentage werkzaam gecorrigeerd wordt zijn leerweg, richting (i.e. sector), niveau en regio. De bedoeling van het toekennen van een negatieve beoordeling (i.e. rood vlaggetje) is om de meest extreme beroepsopleidingen met een evident structureel slechte arbeidsmarktpositie te oormerken. Opleidingen die slecht scoren zonder én met correctie, kunnen als slecht worden beschouwd wat betreft de arbeidsmarktrelevantie. Dit zijn de opleidingen die zonder meer verscherpt toezicht verdienen op dit onderdeel. Ook bij de Inspectie van het Onderwijs is het gebruikelijk om naar beide scores te kijken bij de beoordeling van leerprestaties van scholen.

In figuur 4.7 zijn de percentages werkzaam van beroepsopleidingen (dezelfde als gebruikt in figuur 4.6) gecorrigeerd voor de verschillende kenmerken van de beroepsopleiding: leerweg, richting, niveau en regio. De bedoeling hiervan is om opleidingen met dezelfde kenmerken met elkaar te kunnen vergelijken wat betreft de score op het percentage werkzaam. De resultaten van de regressie-analyse (OLS) met deze kenmerken als verklarende variabelen zijn opgenomen in de bijlage van dit hoofdstuk. 
Uit de resultaten blijkt dat het percentage werkzaam voor bbl gemiddeld I7\%-punt hoger ligt dan voor bol. Naarmate het niveau stijgt, is er een hoger percentage werkzaam. Verder blijkt dat economie slechter scoort dan groen, gezondheidszorg, sociaalcultureel en techniek. Er is met een $\mathrm{R}_{2}$ van $58 \%$ een goede verklaringskracht van de verklarende variabelen voor de variantie van het percentage werkzaam van beroepsopleidingen geclusterd naar regio.

De residuen van de vergelijking zijn weergegeven in figuur 4.7. Ze kunnen worden geïnterpreteerd als de afwijking tussen het werkelijke percentage werkzaam en het percentage dat verwacht mag worden gegeven de kenmerken van de beroepsopleiding. De residuen zijn in statistische zin normaal verdeeld, waardoor er weinig opleidingen voorkomen in de uiteinden van de verdeling. De uiteinden van de verdeling geven weer dat het percentage werkzaam $37 \%$ lager is dan voorspeld, respectievelijk $3 \mathrm{I} \%$ hoger is dan voorspeld. Deze opleidingen doen het dus veel slechter of beter dan verwacht mag worden op basis van de kenmerken van de opleiding. Daarentegen zijn er juist veel opleidingen rondom het gemiddelde van het residu, die dus geen afwijking vertonen ten opzichte van de voorspelling. Bij het $\mathrm{IO}^{\mathrm{e}}$ percentiel is het percentage werkzaam II\% lager dan verwacht mag worden.

\section{Figuur 4.7}

Cumulatieve verdeling van 2.431 beroepsopleidingen per regio, residu van regressie op percentage werkzaam 1 jaar na afstuderen, gemiddelde 2009-2011

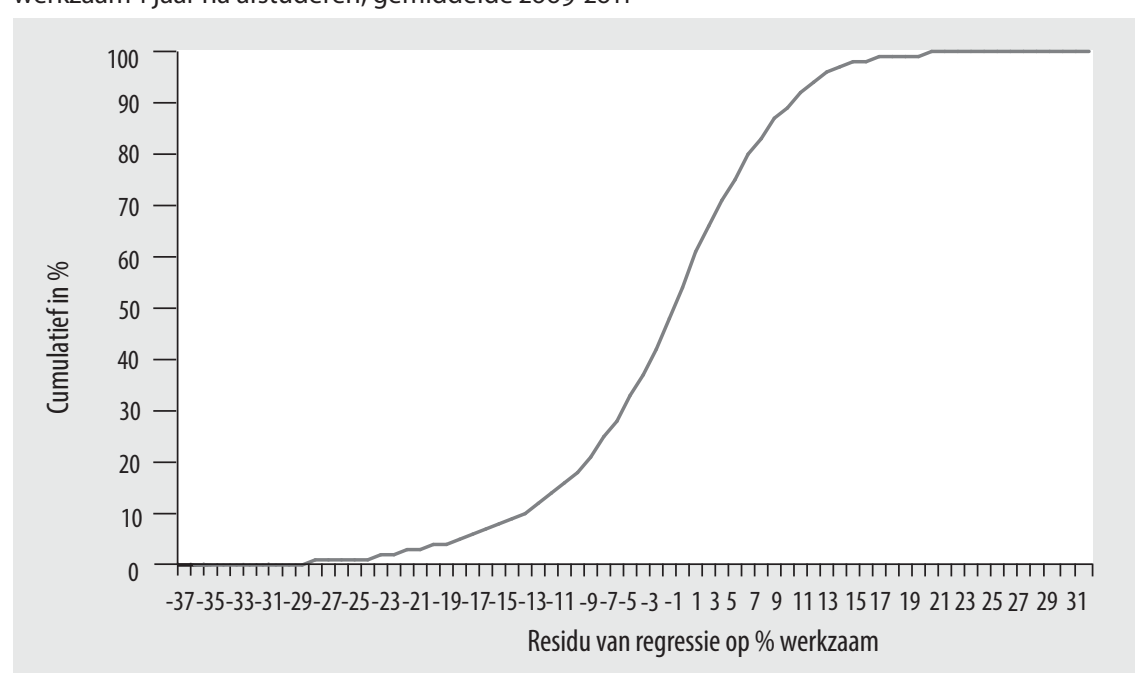

Bron: $\mathrm{CBS} / \mathrm{SSB}$

Een voor de hand liggende werkwijze is nu om te vergelijken waar opleidingen terecht komen in zowel de ongecorrigeerde (figuur 4.6) als de gecorrigeerde verdeling (figuur 4.7). Dit is in tabel 4.2 gedaan voor de onderste $10 \%$ van de opleidingen, dat wil zeggen de IO\% opleidingen die het slechtst scoren in één van beide verdelingen. Eenzelfde 
analyse kan men uiteraard ook uitvoeren voor de $20 \%$ of $30 \%$ slechtst scorende opleidingen. Het blijkt dat 156 van de 2.43 I opleidingen, dat is $6,4 \%$, in de ongecorrigeerde én gecorrigeerde verdeling behoren tot de slechtste I०\% van de opleidingen. Daarnaast zijn er nog ongeveer $7 \%$ opleidingen die tot de slechtste IO\% behoren volgens hetzij het ongecorrigeerde hetzij het gecorrigeerde percentage werkzaam.

Tabel 4.2

Beroepsopleidingen verdeeld naar percentage werkzaam, ongecorrigeerd en gecorrigeerd voor kenmerken van de opleiding

$\begin{array}{lrrr} & \text { Ongecorrigeerd } & & \\ \text { Gecorrigeerd } & \text { Bovenste } 90 \% & \text { Onderste } 10 \% & \text { Totaal } \\ \text { Bovenste } 90 \% & 2.108 & 80 & 2.188 \\ & (86,7 \%) & (3,3 \%) & (90,0 \%) \\ \text { Onderste } 10 \% & 87 & 156 & 243 \\ \text { Totaal } & (3,6 \%) & (6,4 \%) & (10,0 \%) \\ & 2.195 & 236 & 2.431 \\ & (90,3 \%) & (9,7 \%) & (100 \%)\end{array}$

\subsection{Grenswaardes voor de indicator percentage onderbenutting}

In de volgende twee subparagrafen wordt aan de hand van twee methodes gekeken hoe er een grenswaarde voor het percentage onderbenutting kan worden vastgesteld. Het gaat hierbij om:

- Methode I - Absolute grensbepaling;

- Methode 2 - Relatieve grensbepaling.

Bij beide methodes worden de grenswaardes bepaald op een wijze die min of meer overeenkomt met de grensbepaling voor de indicator percentage werkzaam. Bij onderbenutting is het echter niet goed mogelijk om in de verdeling bij de relatieve grensbepaling te corrigeren voor de kenmerken van de opleiding, zoals leerweg, niveau, richting en regio, zoals dat bij het percentage werkzaam is gebeurd. Dat komt doordat er voor onderbenutting (nog) geen gegevens over opleidingen op instellings- of regioniveau beschikbaar zijn. De steekproef van de schoolverlatersenquêtes van het ROA is daartoe te beperkt. Het is wel de bedoeling deze enquêtes gedurende enkele jaren integraal te gaan afnemen onder schoolverlaters, zodat deze gegevens op den duur wel beschikbaar zijn.

\subsubsection{Methode 1 - Absolute grensbepaling}

In Coenen et al. (2009) wordt ingegaan op het verschijnsel onderbenutting en worden verschillende meetmethodes voor onderbenutting besproken. Het blijkt dat in de periode $1996-2007$ de onderbenutting ca. 35\% is onder mbo'ers van niveau I tot en met 4 die deel uitmaken van de werkzame beroepsbevolking van I5 tot 29 
jaar. Voor oudere leeftijdsklassen daalt het percentage naar 20 tot $25 \%$. Evenals bij het percentage werkzaam volgens meetmethode I in paragraaf 4.4.I zijn deze percentages gebaseerd op de Enquête Beroepsbevolking (EBB) van het CBS (zie ook figuur 4.2). Het gemiddelde percentage onderbenutting voor I5-29 jaar stijgt in jaren van laagconjunctuur maar komt niet boven de $40 \%$ uit. Een percentage onderbenutting van maximaal $40 \%$ kan als een streefwaarde voor beroepsopleidingen van onderwijsinstellingen worden gezien, op dezelfde wijze als dat de streefwaarde voor het percentage werkzaam in paragraaf 4.4.I minimaal $80 \%$ was. Zoals eerder aangegeven zijn deze percentages als grenswaardes minder geschikt omdat een heel groot deel van de onderwijsinstellingen hieraan niet zal voldoen. Er gelden ook andere beperkingen voor deze grenswaardes omdat ze gebaseerd zijn op externe arbeidsmarktgegevens. Zo zou het bij de beoordeling van de arbeidsmarktpositie van opleidingen moeten gaan om schoolverlaters enige tijd na afstuderen, en niet om een deel van de werkzame beroepsbevolking. Bovendien wordt bij de vaststelling van onderbenutting aan de hand van de Standaard Beroepenclassificatie (SBC) van het CBS gekeken naar welk deel van de mbo'ers werkzaam is op een beroepsniveau dat lager is dan het middelbaar beroepsniveau. Hierbij is de vaststelling van onderbenutting afhankelijk gemaakt van de gebruikte beroepenclassificatie. ${ }^{29}$

Uit Coenen et al. (2009) blijkt tevens dat het percentage onderbenutting ca. 30\% is voor mbo-schoolverlaters van niveau I tot en met 4 tussen 1996 en 2007. Dit is gemeten aan de hand van de vraagstelling in de ROA-schoolverlatersenquêtes volgens de eerste indicator van onderbenutting in hoofdstuk 3, waarbij het gaat om het door de werkgevers vereiste opleidingsniveau van de baan waarin schoolverlaters werkzaam zijn. Meer recente cijfers voor schoolverlaters in de periode tussen 2008 en 2012 zijn weergegeven in de volgende twee tabellen.

Tabel 4.3 laat het gemiddelde percentage onderbenutting zien op de niveaus 2, 3 en 4 van bol en bbl. Het betreft het percentage schoolverlaters dat werkzaam is in een functie onder het niveau van de opleiding, gemiddeld over de jaren 2008 tot en met 20I2. Bij de kolom min-max is het minimum- respectievelijk maximumpercentage weergegeven dat op elk niveau voorkwam in de vijf verschillende jaren in deze periode en voor de vijf verschillende richtingen binnen de bol- en bbl-variant. De richtingen die onderscheiden worden zijn landbouw, techniek, economie, zorg en welzijn, en gedrag en maatschappij. De onderbenutting daalt over het algemeen als het niveau hoger is. Het percentage onderbenutting is met gemiddeld $34 \%$ hoog voor bbl op niveau 3 ten opzichte van bol niveau 3 en bbl niveau 2. Op niveau 3 is er tevens de grootste variatie in onderbenutting tussen richtingen. Zo is er in 2009 geen onderbenutting voor bbl niveau 3 gedrag en maatschappij, terwijl de onderbenutting in 2008 $53 \%$ is voor bbl niveau 3 landbouw. Op niveau 4 is het percentage onderbenutting het laagst en gelijk voor beide leerwegen (I6\%). Hieruit kan afgelezen worden dat er grote

29. Inmiddels heeft het CBS de SBC vervangen door de ISCO (de internationale beroepenclassificatie). 
verschillen zijn in onderbenutting tussen leerweg, niveau en richting, en tussen de verschillende waarnemingsjaren in deze periode.

\section{Tabel 4.3}

Percentage onderbenutting voor schoolverlaters van bol en bbl, gemiddelde, minima en maxima van richtingen per jaar en niveau, 2008-2012

\begin{tabular}{|c|c|c|c|c|}
\hline & b & & $\mathrm{bb}$ & \\
\hline & gemiddelde & $\min -\max$ & gemiddelde & $\min -\max$ \\
\hline & $\%$ & $\%$ & $\%$ & $\%$ \\
\hline Niv. 2 & 29 & $14-43$ & 33 & $6-46$ \\
\hline Niv. 3 & 23 & $7-47$ & 34 & $0-53$ \\
\hline Niv. 4 & 16 & $6-32$ & 16 & $0-33$ \\
\hline
\end{tabular}

Bron: ROA/SIS

In tabel 4.4 is de gemiddelde onderbenutting over de periode 2008-20I2 weergegeven, gedifferentieerd naar niveau en richting. Op alle niveaus is de onderbenutting hoger bij landbouw, techniek en economie dan voor de andere twee richtingen. Bij bbl op niveau 3 zijn de percentages onderbenutting zelfs hoger dan $40 \%$ in de richtingen landbouw, techniek en economie. Gemiddeld over alle richtingen en niveaus in tabel 4.4 is de onderbenutting $25 \%$, voor bol $23 \%$ en bbl $26 \%$.

Tabel 4.4

Percentage onderbenutting voor schoolverlaters van bol en bbl naar niveau en richting, gemiddelde 2008-2012

\begin{tabular}{|c|c|c|c|}
\hline & & $\begin{array}{r}\text { bol } \\
\%\end{array}$ & $\begin{array}{r}\text { bbl } \\
\%\end{array}$ \\
\hline \multirow[t]{5}{*}{ Niv. 2} & Landbouw & 22 & 35 \\
\hline & Techniek & 25 & 33 \\
\hline & Economie & 38 & 39 \\
\hline & Zorg en welzijn & 21 & 20 \\
\hline & Gedrag en maatschappij & - & - \\
\hline \multirow[t]{5}{*}{ Niv. 3} & Landbouw & 36 & 45 \\
\hline & Techniek & 32 & 45 \\
\hline & Economie & 31 & 40 \\
\hline & Zorg en welzijn & 20 & 22 \\
\hline & Gedrag en maatschappij & 14 & 7 \\
\hline \multirow[t]{5}{*}{ Niv. 4} & Landbouw & 27 & 17 \\
\hline & Techniek & 19 & 24 \\
\hline & Economie & 21 & 28 \\
\hline & Zorg en welzijn & 8 & 6 \\
\hline & Gedrag en maatschappij & 12 & 9 \\
\hline
\end{tabular}

Bron: ROA/SIS 
Uit de gepresenteerde gemiddeldes van het percentage onderbenutting in de tabellen 4.3 en 4.4 blijkt dat de eerder genoemde streefwaarde van $40 \%$, gebaseerd op externe arbeidsmarktgegevens van de werkzame beroepsbevolking, een vrij hoog percentage is. Desondanks zijn er nog veel richtingen, niveaus en jaren waarvoor de onderbenutting gemiddeld nog hoger is. De percentages hebben immers betrekking op gemiddeldes van meerdere beroepsopleidingen van onderwijsinstellingen, en tabel 4.4 ook over een periode van vijf jaar. Een deel van de beroepsopleidingen heeft daarom een flink hogere onderbenutting. Hoewel uit de ROA-schoolverlatersenquêtes gegevens over onderbenutting van opleidingen niet betrouwbaar samen te stellen zijn op instellingsniveau, kan er wel naar de landelijke gemiddeldes voor de opleidingen in de verschillende richtingen worden gekeken. In de volgende subparagraaf wordt gekeken naar de verdeling van de gemiddelde percentages onderbenutting voor de verschillende opleidingen. Een grens- of streefwaarde van $40 \%$ kan gebruikt worden vanuit de gedachte dat, op termijn, een dergelijk percentage voor de meeste opleidingen te halen moet zijn, ongeacht leerweg, niveau en richting.

\subsubsection{Methode 2 - Relatieve grensbepaling}

Een alternatief voor de absolute grensbepaling is te kiezen voor de relatieve grensbepaling. Dit kan gebeuren aan de hand van de schoolverlatersgegevens van het ROA (SIS), waarbij wederom geselecteerd is op opleidingen met tussen 2007 en $201 \mathrm{~m}$ minstens 20 responderende schoolverlaters. Dit heeft geresulteerd in ruim Ioo beroepsopleidingen waarvoor het landelijke percentage onderbenutting kan worden gepresenteerd. Uit figuur 4.8 blijkt dat er een lange staart van opleidingen is met een hoge onderbenutting, te beginnen bij $76 \%$ (meer dan driekwart) onderbenutting. Pas voorbij het $15^{\mathrm{e}}$ à $20^{\mathrm{e}}$ percentiel gaat de onderbenutting flink dalen. Maar liefst $23 \%$ van de opleidingen niet kan voldoen aan de eerder genoemde streefwaarde van $40 \%$ onderbenutting. Omdat dit veel opleidingen betreft, lijkt het redelijk om een minder strenge grenswaarde te kiezen. Het $\mathrm{IO}^{\mathrm{e}}$ percentiel van de beroepsopleidingen heeft een onderbenutting van $53 \%$, en bij het $13^{\mathrm{e}}$ percentiel is er sprake van $50 \%$ onderbenutting, dat is ongeveer twee keer zo hoog als de gemiddelde onderbenutting. Bij de relatieve grens van het $\mathrm{IO}^{\mathrm{e}}$ percentiel kan derhalve een absolute grenswaarde van ca. $50 \%$ worden afgeleid. Het vaststellen van een relatieve grens blijft wat arbitrair, maar ook hier lijkt het IO\%-criterium redelijk te zijn, mede omdat de onderbenutting bij het $\mathrm{IO}^{\mathrm{e}}$ percentiel betrekking heeft op meer dan helft van de werkzame schoolverlaters. 


\section{Figuur 4.8}

Cumulatieve verdeling van ca. 100 beroepsopleidingen naar percentage onderbenutting, gemiddelde 2007-2011

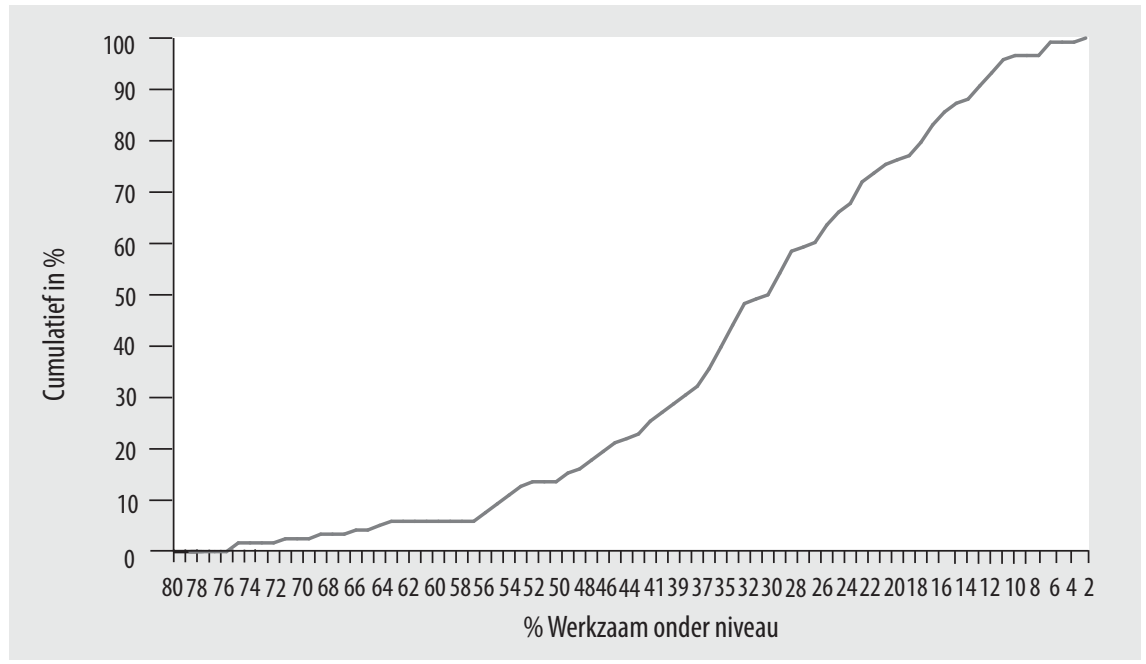

Bron: ROA/SIS

Om te corrigeren voor conjuncturele ontwikkelingen ligt het voor de hand een meerjarig gemiddelde te nemen. Figuur 4.9 laat dit ook zien. In de figuur zijn voor vijf afzonderlijke jaren de percentages onderbenutting weergegeven die bij de percentielen in de verdeling horen. De verschillen tussen de jaren wat betreft onderbenutting zijn vooral groot bij opleidingen die onderaan de verdeling zitten, dus de opleidingen die het slechtst scoren qua onderbenutting. Aan de eerder genoemde streefwaarde van maximaal $40 \%$ onderbenutting kan ongeveer $30 \%$ van de opleidingen niet voldoen. Bij dit $30^{\mathrm{e}}$ percentiel varieert de onderbenutting van $36 \%$ in 2007 (hoogconjunctuur) tot $43 \%$ in 20 II (laagconjunctuur). Het percentage onderbenutting ligt tussen de ruim 40 en $50 \%$ bij het $20^{\mathrm{e}}$ percentiel. Voor de $10 \%$ slechtst scorende opleidingen is de onderbenutting meer dan $50 \%$ tot wel $70 \%$ in jaren van laagconjunctuur. 
Figuur 4.9

Verdeling naar percentielen van onderbenutting onder schoolverlaters, 2007-2011

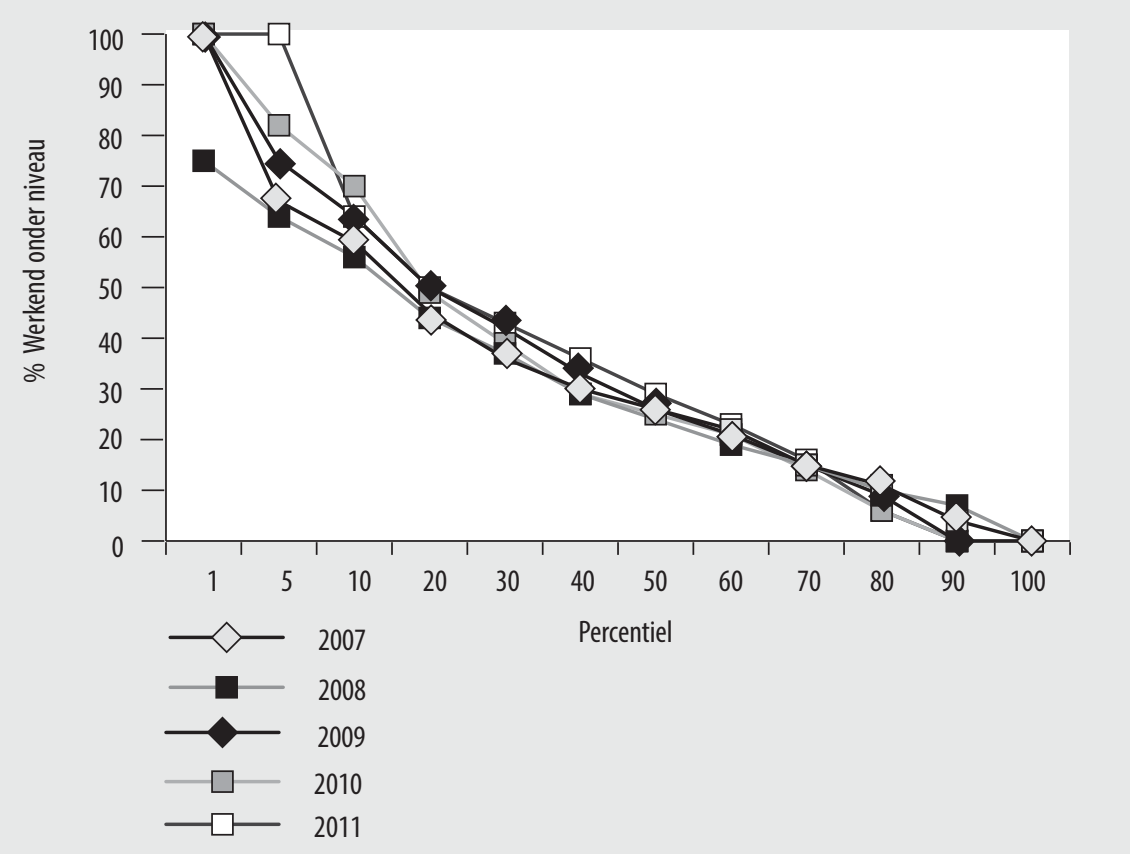

Bron: ROA/SIS

\subsection{Huidig en toekomstig arbeidsmarktperspectief van beroepsopleidingen}

Tot slot wordt er bij de inkadering van de indicatoren van beroepsopleidingen ook gekeken naar het toekomstperspectief voor schoolverlaters. Hiervoor wordt gebruik gemaakt twee indicatoren van zowel het ROA (ITA: Indicator Toekomstig Arbeidsmarktperspectief) als het SBB (Kans op werk). Beide indicatoren hebben voor- en nadelen, maar kunnen elkaar in potentie goed aanvullen. Bij de twee indicatoren voor toekomstperspectief worden absolute grenzen gebruikt. Dat komt mede doordat ze gebaseerd zijn op de berekening van de verhouding tussen de toekomstige vraag en het toekomstige aanbod. Daardoor is het gemakkelijker een ijkpunt vast te stellen, namelijk bij het punt waarop vraag en aanbod min of meer in evenwicht zijn.

Het toekomstig arbeidsmarktperspectief is naast het huidige arbeidsmarktperspectief om twee redenen van belang, die samenhangen met de sturing van de instroom. Ten eerste betekent een slechte arbeidsmarktsituatie voor de schoolverlaters van nu niet dat deze blijft voorbestaan als de huidige cohorten van leerlingen als schoolverlater op de arbeidsmarkt instromen. De instroom in de opleiding kan immers al lager zijn geworden, of de arbeidsvraag kan in de tussentijd groter zijn geworden. Als de 
instroom in de opleiding teveel wordt gestuurd op de huidige arbeidsmarktsituatie kan dat het risico op een zogenaamde 'varkenscyclus' vergroten. Door te kijken naar de toekomstige situatie wordt dit risico verkleind.

Ten tweede wordt bij het gebruik van de arbeidsmarktgegevens van schoolverlaters teruggekeken in de tijd, omdat er meestal geen hele actuele arbeidsmarktinformatie op grootschalige en vergelijkbare wijze beschikbaar is. Overigens is het houden van toezicht per definitie terugkijken om de situatie in te schatten, waarbij vaak meerdere jaren in ogenschouw worden genomen om het sturen op incidentele gebeurtenissen of min of meer toevallige fluctuaties zoveel mogelijk te voorkomen. Toch is het zinvol en mogelijk om bij de beoordeling van de arbeidsmarktrelevantie van opleidingen ook te kijken naar de toekomst om de risico's op een slecht arbeidsmarktperspectief in te kunnen schatten.

$\mathrm{Er}$ is echter een aantal nadelen verbonden aan het gebruik van arbeidsmarktinformatie voor de toekomst. Deze nadelen houden verband met het de kwaliteit van de arbeidsmarktprognoses, de beperkte beschikbaarheid van gedetailleerde data over de regionale arbeidsmarkt, en het concept van arbeidsvraag- en aanbod in de regio, en worden hieronder besproken.

- Ten eerste is er onvermijdelijk een foutenmarge bij prognoses. Het ROA evalueert geregeld de kwaliteit van de prognoses. Uit de evaluatie van voorgaande prognoses blijkt dat voor ca. de helft van de opleidingstypen de juiste van de vijf mogelijke typeringen werd gegeven. Voor ca. $80 \%$ van de opleidingstypen werd de juiste of een aangrenzende typering voorspeld, en voor to tot $20 \%$ van de onderscheiden opleidingstypen zat men er geheel naast (Dupuy, 2009 en Bertrand-Cloodt, 20Io). Hoewel de publicatie van deze toekomstinformatie over opleidingen erop gericht is te voorkomen dat de slechte arbeidsmarktperspectieven bewaarheid worden, noopt dit toch tot enige voorzichtigheid bij het gebruik van toekomstige arbeidsmarktperspectieven om de arbeidsmarktrelevantie van opleidingen te beoordelen.

- Verder is er het bij het samenstellen van toekomstige arbeidsmarktperspectieven over beroepsopleidingen vaak heel moeilijk of onmogelijk en deels onzinnig om te differentiëren naar opleidingen op instellingsniveau. Ten eerste ontbreken vaak de arbeidsmarktgegevens om prognoses te maken van bijvoorbeeld de uitbreidings- en vervangingsvraag op lokaal niveau. Het gebrek aan voldoende gedetailleerde arbeidsmarktgegevens makt dat de prognoses van het ROA tot op heden niet differentiëren naar niveau 2, 3 of 4 (niveau I is wel apart), en dat de opleidingstypen waarover gepubliceerd wordt op landelijk niveau een cluster vormen van arbeidsmarktverwante beroepsopleidingen. Op regionaal niveau zijn er sinds kort arbeidsmarktprognoses voor de 35 regio's beschikbaar, maar hierbij worden slechts vijf brede opleidingscategorieën onderscheiden (groen, techniek, sociaal-cultureel, gezondheidszorg en economie). Ten tweede is de confrontatie tussen arbeidsaanbod en arbeidsvraag conceptueel gezien niet te definiëren op instellingsniveau. Dezelfde 
opleidingen van verschillende ROC's worden geconfronteerd met dezelfde arbeidsvraag uit de regio, en bij min of meer gelijke kwaliteit van deze opleidingen maakt het voor werkgevers waarschijnlijk weinig uit bij welk ROC een schoolverlater het diploma heeft behaald. Bovendien is de arbeidsmarktdynamiek erg groot, waardoor er substitutie tussen segmenten op de arbeidsmarkt (opleidingen) maar ook tussen regio's kan optreden (zie bijv. Clerkx et al. 20I4).

- Tot slot worden er wel zeer gedetailleerde arbeidsmarktprognoses gepubliceerd door SBB (20I4). De publicatie van toekomstperspectieven over beroepsopleidingen voor de verschillende niveaus en op regionaal niveau is op zichzelf een voordeel ten opzichte van de prognoses van het ROA. De publicaties over de indicator 'Kans op werk' zijn beschikbaar via internet op de websites van SBB en UWV. Uit een recente review (oktober 20I3) is echter gebleken dat de kwaliteit van de indicator verder verbeterd moet worden. De interpretatie van de indicator betreft de 'Kans op werk in het verlengde van de opleiding', waarbij een sterke I-op-I relatie tussen opleiding en beroep of branche wordt verondersteld. Het nadeel hiervan is dat de aansluiting met de arbeidsmarkt voor veel opleidingen goed kan zijn terwijl de schoolverlaters van deze opleidingen in banen terecht komen over de hele breedte van de arbeidsmarkt en slechts een deel van hen gaat werken in de institutioneel beoogde beroepen of branches. Deze en andere punten die uit de review naar voren zijn gekomen worden inmiddels door SBB nader bestudeerd, waarbij er een verbetertraject in gang is gezet, bestaande uit de volgende acties:

- Een nadere toelichting op de huidige methodiek van 'Kans op werk' en 'Kans op stage', die openbaar wordt gemaakt.

- Versterking van de externe feedback door een overleggroep te installeren voor ondersteuning en advies voor de verdere doorontwikkeling van de methodiek kans op werk.

- Het voornemen om een tweede overleggroep in het leven te roepen over de bruikbaarheid van data, en verschillen en overeenkomsten met andere beschikbare data.

- Het onderzoeken van de effecten die optreden door het afgeven van arbeidsmarktkansen. Met andere woorden: leiden goede kansen tot meer studenten en geringe kansen tot een daling van studentendeelname?

Er zijn twee mogelijke oplossingen voor de bovengenoemde nadelen van de arbeidsmarktprognoses. Ten eerste kunnen de arbeidsmarktprognoses van het ROA en het SBB gecombineerd worden, waarbij die van het ROA een kader bieden voor een nadere detaillering door SBB. Ten tweede dient bij de beoordeling van de arbeidsmarktrelevantie van opleidingen de huidige arbeidsmarktsituatie meer gewicht te krijgen dan de toekomstige. In de tabellen 4.5 en 4.6 wordt dit gedaan voor respectievelijk het percentage werkzaam en het percentage onderbenutting in combinatie met de absolute typering van de arbeidsmarktperspectieven zoals deze door ROA (en ook SBB) worden gegeven. Opleidingen die zowel een erg laag percentage werkzaam (of 
erg hoog percentage onderbenutting) hebben als een slecht of matig toekomstperspectief op de arbeidsmarkt, hebben extra aandacht nodig van onderwijsinstellingen. Er zullen dan maatregelen moeten worden genomen om het tij te keren. Hierop wordt nader ingegaan in het volgende hoofdstuk. Als deze opleidingen echter een (erg) goed of redelijk toekomstig arbeidsmarktperspectief hebben, is dit reden om na te gaan waardoor de arbeidsmarktsituatie aan het veranderen is. Dit is nodig om zich ervan te vergewissen dat het toekomstperspectief inderdaad verbetert, en om te voorkomen dat teveel sturing op recente arbeidsmarktgegevens leidt tot varkenscycli voor deze opleidingen.

\section{Tabel 4.5}

Vaststelling van beroepsopleidingen die extra aandacht behoeven aan de hand van percentage werkzaam en toekomstperspectief

Toekomstperspectief:
\% Werkzaam (positie in de verdeling)
Erg hoog
Hoog
Gemiddeld
Laag
Erg laag

Tabel 4.6

Vaststelling van beroepsopleidingen die extra aandacht behoeven aan de hand van percentage onderbenutting en toekomstperspectief

Toekomstperspectief:
\% Onderbenutting (positie in de verdeling)
Erg laag
Laag
Gemiddeld
Hoog
Erg hoog

\subsection{Conclusies}

In dit hoofdstuk is aangegeven wat de voordelen zijn van het gebruik van absolute en relatieve grenswaardes voor de arbeidsmarktrelevantie van opleidingen. Er zijn in dit hoofdstuk vier criteria besproken waaraan grenswaardes bij voorkeur dienen te voldoen. Ze dienen zoveel mogelijk probleemgericht, realistisch, eenvoudig en robuust te zijn. Wat betreft de probleemgerichtheid, is uit hoofdstuk 3 gebleken dat de arbeidsmarktrelevantie van opleidingen het best bekeken kan worden aan de hand van twee indicatoren, het percentage werkzaam en het percentage onderbenutting van schoolverlaters. Een laag percentage werkzaam en/of een hoog percentage 
onderbenutting geeft een potentieel probleem weer voor de arbeidsmarktrelevantie. ${ }^{30}$ Realistische grenswaardes zetten onderwijsinstellingen aan tot maatregelen om de arbeidsmarktrelevantie van opleidingen te verbeteren. Gemiddelde percentages over alle opleidingen kunnen als streefwaardes worden beschouwd, maar zijn niet zo realistisch om te handhaven omdat er veel opleidingen zijn die een grenswaarde op basis van een gemiddelde niet halen. Een absoluut percentage is echter zeer eenvoudig toe te passen, en wordt tevens wat robuuster (minder afhankelijk van de conjunctuur) als er over meerdere jaren wordt gemiddeld. Grenzen gebaseerd op relatieve grensbepaling zijn realistisch als er bijvoorbeeld uit wordt gegaan van IO\% van de slechtst scorende opleidingen. Onderwijsinstellingen weten dan echter van te voren minder goed waar ze aan toe zijn dan bij een absolute grenswaarde, omdat de relatieve grenswaarde mede afhankelijk is van hoe andere onderwijsinstellingen scoren op de indicatoren voor de arbeidsmarktrelevantie. Correcties voor de kenmerken van de opleidingen maken dat de grenswaardes realistischer worden maar minder eenvoudig toe te passen, omdat er statistische schattingen nodig zijn die bovendien niet altijd robuust zijn.

Wat betreft het percentage werkzaam is gebleken dat er een minimale streefwaarde kan worden vastgesteld voor onderwijsinstellingen, bijvoorbeeld $80 \%$. Het gemiddelde van $80 \%$ wordt zelfs in conjunctureel minder goede jaren gehaald onder jongeren met een mbo-diploma, maar berust op de gedachte dat een dergelijk gemiddelde voor alle opleidingen haalbaar moet zijn. Een grenswaarde om de grootste probleemopleidingen in kaart te brengen zal dus substantieel lager moeten liggen.

De literatuur geeft geen goede onderbouwing voor welk percentage te kiezen als grenswaarde. In dat opzicht kan er een parallel getrokken worden met de vsv-aanpak. De vsv-aanpak laat zien dat het vaststellen van absolute grenswaardes vooral een kwestie van ambitie is, die samenhangt met hoe urgent een probleem wordt ervaren en de inspanningen die men wil plegen om de situatie te verbeteren. De urgentie van het probleem wordt duidelijk als de schadelijke effecten die samenhangen met het voortijdig schoolverlaten, of met een slechte arbeidsmarktrelevantie, nader worden bestudeerd. In hoofdstuk 2 is wel al gewezen op het productiviteitsverlies door een slechte arbeidsmarktintrede van schoolverlaters, en eventuele 'scarring' effecten later in de loopbaan.

Bij de keuze voor een relatieve grenswaarde wordt gekeken naar de percentielscore die hoort bij de slechtst scorende opleidingen in de statistische verdeling. Hierbij kunnen voor de vaststelling of opleidingen die onder deze grens vallen wel of geen correcties voor de kenmerken van de opleiding (niveau, leerweg, richting en regio) worden toegepast. Dit lijkt op de praktijk zoals die bij de Inspectie van het Onderwijs reeds

30. In dit hoofdstuk worden deze twee indicatoren los van elkaar beschouwd, en wordt in de laatste paragraaf erop ingegaan dat ze kunnen worden gecombineerd met een indicatie van het toekomstperspectief. In het recent verschenen onderwijsverslag van de Inspectie van het Onderwijs (2014) worden beide indicatoren wel in één figuur geplaatst (zie figuur 6) om inzicht te geven in de arbeidsmarktrelevantie van mbo-opleidingen naar niveau en richting. 
bestaat. Voor verschillende indicatoren in het risicotoezicht wordt vaak gekeken naar de onderste IO\% als deel van de populatie dat extra toezicht nodig heeft.

Uit diverse analyses van de frequentieverdelingen in dit hoofdstuk blijkt dat een benchmark van gemiddeld ongeveer $70 \%$ werkzaam voor opleidingen een redelijk uitgangspunt is. Dat percentage werkzaam heeft betrekking op $13 \%$ van de opleidingen. Indien men uit wil gaan van precies IO\% van de slechtst scorende opleidingen, dan is de bijbehorende grenswaarde $67 \%$. Als er gecorrigeerd wordt voor de diverse kenmerken van een opleiding, dan scoort de slechtste IO\% van de opleidingen II\% lager dan verwacht mag worden op basis van de kenmerken niveau, leerweg, richting en regio. Als de laatste twee grenzen tegelijk worden toegepast, dan heeft deze combinatie betrekking op ruim 6\% van de opleidingen. Dit zijn de opleidingen die zowel zonder als met correctie het slechtst scoren op het percentage werkzaam. In tabel 4.7 zijn de verschillende grenswaardes overzichtelijk bij elkaar gezet.

Tabel 4.7

Absolute en relatieve grenswaardes voor het percentage werkzaam onder schoolverlaters

\begin{tabular}{llrr}
\hline Grensbepaling & $\begin{array}{c}\text { Absolute grens } \\
\text { min. \% werkzaam }\end{array}$ & $\begin{array}{r}\text { Relatieve grens= } \\
\text { \% opleidingen }\end{array}$ \\
Streefwaarde & ongecorrigeerd & $80 \%$ & $28 \%$ \\
\hline \multirow{3}{*}{ Grenswaarde } & (1) ongecorrigeerd & $70 \%$ & $13 \%$ \\
& (2) ongecorrigeerd & $67 \%$ & $10 \%$ \\
& (3) afwijking na correctie & $-11 \%$ & $10 \%$ \\
& (2) \& (3) combinatie & & $6 \%$
\end{tabular}

Ook bij het percentage onderbenutting kan een absolute grenswaarde worden gehanteerd. Op basis van gegevens uit de beroepsbevolking zou 40\% onderbenutting als uitgangspunt kunnen gelden. In de landelijke statistische verdeling gaat het dan om $23 \%$ van de opleidingen. Een percentage van 50\% dat betrekking heeft op I3\% van de opleidingen is dan waarschijnlijk realistischer. In dat geval gaat het dus om opleidingen waarvan meer dan de helft van de schoolverlaters werkt in een baan onder het niveau van de opleiding. Om precies IO\% van de slechtst scorende opleidingen te identificeren, moet de grenswaarde op $52 \%$ onderbenutting worden vastgesteld. De verschillende grenswaardes voor onderbenutting zijn bij elkaar gezet in tabel 4.8.

Tabel 4.8

Absolute en relatieve grenswaardes voor het percentage onderbenutting onder schoolverlaters

\begin{tabular}{|llrr} 
& Grensbepaling & $\begin{array}{r}\text { Absolute grens } \\
\text { max. onderbenutting }\end{array}$ & $\begin{array}{r}\text { Relatieve grens }= \\
\% \text { opleidingen }\end{array}$ \\
\hline Streefwaarde & ongecorrigeerd & $40 \%$ & $23 \%$ \\
Grenswaarde & ongecorrigeerd & $50 \%$ & $13 \%$ \\
& ongecorrigeerd & $52 \%$ & $10 \%$
\end{tabular}


Voor het opnemen van toekomstige arbeidsmarktperspectieven in het beoordelingskader dient er nog een kwaliteitsslag gemaakt te worden bij het samenstellen van de arbeidsmarktprognoses. Zolang deze slag niet is gemaakt, kan er beter uitsluitend gebruik worden gemaakt van de informatie over de huidige arbeidsmarktsituatie. 



\section{Invulling van het beoordelings- kader}

\section{$5.1 \quad$ Inleiding}

Als opleidingen in het beoordelingskader onder de grenswaarde komen is dit reden voor onderwijsinstellingen om nader te analyseren of er daadwerkelijk sprake is van een probleem. Indien daar inderdaad sprake van is, kunnen instellingen actie ondernemen. Als instellingen dat niet doen en de prestaties van de opleiding blijven onder de maat kan dit reden zijn om een handhavingstraject te starten. Instellingen kunnen het in dat proces aangeven als zij het niet eens zijn met een eventueel negatief oordeel. $\mathrm{Zij}$ zouden dit kunnen doen aan de hand van zowel kwantitatieve als kwalitatieve indicatoren. Hierbij kan geput worden uit indicatoren van het ROA (bijv. toekomstperspectief, spijt van de opleiding na afstuderen) en SBB ('Kans op werk' of 'Kans op stage'), of indicatoren uit eigen enquêtes of gebaseerd op ander onderzoek. Het is aan de handhaver te beoordelen of er voldoende aanleiding is om zijn oordeel over de arbeidsmarktrelevantie van de betreffende opleidingen bij te stellen. In figuur 5.I is de voorgestelde procedure weergegeven.

Gezien de vooralsnog beperkte beschikbaarheid en bruikbaarheid van de indicatoren voor de toekomstige arbeidsmarktsituatie, wordt voorgesteld de indicatoren voor de toekomstige arbeidsmarktsituatie in eerste instantie niet te gebruiken bij de selectie van opleidingen zitten die extra aandacht behoeven. Onderwijsinstellingen zouden deze indicatoren wel kunnen gebruiken om onderbouwing aan te dragen voor de arbeidsmarktrelevantie van opleidingen die een erg lage arbeidsdeelname van schoolverlaters hebben (laag percentage werkzaam) of waarvan veel schoolverlaters onder hun niveau werken (hoog percentage onderbenutting). 


\section{Figuur 5.1}

Procedure voor de beoordeling van de arbeidsmarktrelevantie van beroepsopleidingen

Selectie van de slechtst scorende opleidingen naar:

- \% werkzaam

- $\%$ onderbenutting

\begin{tabular}{l}
\hline \\
Is de arbeidsmarktrelevantie van de opleiding \\
voldoende? \\
• JA => geen nader onderzoek of extra toezicht nodig \\
- NEE => nader onderzoek nodig \\
- Maatregelen van de onderwijsinstelling en/of OCW \\
- Geen extra toezicht nodig, wellicht aanvullende \\
afspraken \\
Indien NEE: \\
- Kan de onderwijsinstelling aantonen dat de \\
relevantie van de opleiding voor de \\
arbeidsmarkt toch voldoende is: \\
- Toekomstperspectief? \\
- Spijt van de opleiding? \\
- Kans op stage? \\
- Andere indicatoren? \\
- On goorstroom naar vervolgonderwijs?
\end{tabular}


Daarnaast kunnen onderwijsinstellingen erop wijzen dat er omstandigheden zijn waardoor wellicht minder zwaar getild moet worden aan het oordeel over de arbeidsmarktrelevantie van opleidingen. Ook dit is in de figuur aangegeven. Als veel gediplomeerden doorstromen naar een vervolgopleiding, en deze gediplomeerden tevreden zijn over de opleiding als basis voor het vervolgonderwijs, dan legt de arbeidsmarktrelevantie vanzelfsprekend wat minder gewicht in de schaal bij de beoordeling. Ook kunnen onderwijsinstellingen al overleg voeren met 'stakeholders' in de regio als ze in een eerder stadium een gebrekkige arbeidsmarktrelevantie hebben geconstateerd. Als daar aantoonbaar maatregelen uit naar voren zijn gekomen om de situatie te verbeteren, dan is een negatieve beoordeling en extra toezicht wellicht niet nodig.

De volgende paragraaf gaat eerst in op het leerproces dat verbonden is aan het opstellen van een beoordelingskader voor de arbeidsmarktrelevantie. Het gebruik en de interpretatie van arbeidsmarktgegevens vergen immers zowel bij de handhaver als de onderwijsinstellingen voldoende kennis over de aansluiting tussen onderwijs en arbeidsmarkt. Paragraaf 5.3 laat zien welke opleidingen extra aandacht behoeven op basis van de beschikbare arbeidsmarktgegevens over het percentage werkzaam en het percentage onderbenutting. Paragraaf 5.4 geeft vervolgens een nadere toelichting op de wijze waarop onderwijsinstellingen kunnen aantonen dat ze toch de zorgplicht voor hun leerlingen en schoolverlaters nakomen, zelfs als de indicatoren percentage werkzaam of percentage onderbenutting in eerste instantie tot een negatieve beoordeling van de arbeidsmarktrelevantie van een opleiding hebben geleid. Paragraaf 5.5 sluit af met de conclusies.

\subsection{Leerproces voor onderwijsinstellingen en handhaver}

In deze paragraaf willen we drie belangrijke aandachtspunten bespreken die volgens ons belangrijk zijn bij het opstellen van het beoordelingskader en het opstarten van het proces van beoordeling van opleidingen. Ten eerste gaat het erom de beroepsopleidingen op te sporen waarvoor het evident is dat het arbeidsmarktperspectief structureel slecht is. De instellingen van deze opleidingen hebben wat uit te leggen. De uitleg kan gebeuren aan de hand van aanvullend cijfermateriaal, afwegingen of reeds genomen acties die niet in eerste aanleg bekend zijn bij de instantie die toeziet op de handhaving. Vervolgens is het aan de handhaver om een afweging te maken ten aanzien van het niet voldoen aan de zorgplicht arbeidsmarktperspectief door de onderwijsinstelling.

Ten tweede betekent een slecht arbeidsmarktperspectief van een beroepsopleiding in onze ogen niet per se dat deze opleiding niet langer meer bekostigd of aangeboden moet worden, en ook niet dat er een plafond voor de instroom in de opleiding moet worden vastgelegd. Er zijn ook vele andere mogelijkheden om de instroom te beperken of de arbeidsmarktpositie van schoolverlaters van deze opleidingen te verbeteren: 
- Het geven van een krachtig en duidelijk signaal aan studiekiezers dat de betreffende opleiding een slecht perspectief biedt op een baan (in het verlengde van de opleiding, in de regio). Dat kan door duidelijke waarschuwingen in de informatiebrochures van de opleiding, tijdens de voorlichtingsbijeenkomsten of tijdens de entree-, studiekeuze- of ombuiggesprekken. Dit betekent niet dat de opleiding geen deelnemers meer zal trekken, maar wel dat de instroom in de opleiding waarschijnlijk zal afnemen. Een daling van de instroom met IO\% zou bijvoorbeeld al veel kunnen helpen om het arbeidsmarktperspectief in termen van werkloosheid of percentage werkzaam significant te doen verbeteren;

- Het binnen het kader van de landelijk vastgestelde kwalificatiestructuur veranderen van het curriculum zodat de opleiding beter aansluit op de arbeidsmarkt. Ook kan hier worden gedacht aan het zwaarder maken van de opleiding, voor zover het kwalificatiedossier dit toelaat, zodat er een strengere (zelf) selectie plaatsvindt van leerlingen. Indien nodig kan er een soortgelijke opleiding worden opgestart met een aangepast kwalificatieprofiel;

- Het samenvoegen van de beroepsopleiding op één locatie met dezelfde opleiding(en) elders in de regio. Hierdoor wordt de instroom in de opleiding waarschijnlijk afgeremd door de grotere reisafstand van potentiële studiekiezers (zie Bertrand-Cloodt et al., 20II), terwijl de toegankelijkheid toch grotendeels gewaarborgd blijft.

- Het ombouwen van de leerweg van een opleiding van een beroepsopleidende (bol) naar een beroepsbegeleidende leerweg (bbl). Hierdoor wordt de opleiding vraaggerichter, waarbij naar verwachting ook de instroom in de opleiding zal worden beperkt, met als gevolg een hogere arbeidsparticipatie na afstuderen. De toegankelijkheid van de opleiding wordt in dit geval gerelateerd aan mate waarin leerlingen opleidingsplaatsen bij bedrijven kunnen bemachtigen.

- Het beter begeleiden van leerlingen naar de arbeidsmarkt als ze zijn afgestudeerd, bijvoorbeeld door te helpen bij de arbeidsbemiddeling naar minder voor de hand liggende bedrijven, of bij het zoeken naar werk in andere regio's.

Ten derde is het van belang in te zien dat de inkadering van het arbeidsmarktperspectief voorlopig waarschijnlijk nog enige 'trial and error' zal vergen. Er is over het algemeen weinig ervaring met het gebruik van arbeidsmarktgegevens op instellingsniveau. ${ }^{3 \mathrm{I}}$ Bovendien zijn vooral de gegevens over toekomstperspectief maar ook over onderbenutting (nog) niet betrouwbaar genoeg om te publiceren voor de diverse beroepsopleidingen binnen een instelling. Een deel van de onderwijsinstellingen heeft wel cijfers over de arbeidsmarktpositie van hun afgestudeerden, maar tot nu toe wordt daarover nauwelijks op structurele en eenduidige wijze gerapporteerd. Bovendien lijken deze gegevens nauwelijks te worden gebruikt voor het beleid op instellingsniveau. Derhalve is er weinig ervaring met de interpretatie van arbeidsmarktgegevens, en hoe deze optimaal benut kunnen worden. Ook is er bij de handhaving en extern

3I. Wel is er de laatste jaren veel aandacht uitgegaan naar het terugdringen van de uitstroom van voortijdig schoolverlaters (vsv'ers), zoals is gebleken uit hoofdstuk 4. 
toezicht tot nu toe slechts in beperkte mate ervaring opgebouwd met het gebruik van arbeidsmarktgegevens.

De obstakels voor het gebruik van arbeidsmarktgegevens in het beoordelingskader gelden in het bijzonder voor kleine of nieuwe opleidingen. Eén van de problemen is dat veel kleine opleidingen met het oog op de betrouwbaarheid van arbeidsmarktgegevens worden uitgesloten in de standaardbeoordeling op arbeidsmarktrelevantie. Voor het percentage werkzaam van het CBS is er voor opleidingen op instellingsniveau informatie beschikbaar zolang deze betrekking heeft op minimaal vijf schoolverlaters. Voor het percentage onderbenutting zijn aanvullende inspanningen nodig om gegevens op het niveau van opleidingen en instellingen te kunnen samenstellen. Tot nu toe is het vrijwel uitsluitend mogelijk om op landelijk niveau arbeidsmarktgegevens over grote opleidingen te publiceren (zie ROA, 20I3). Het ROA levert in de zomer van $20 I 4$ voor het eerst landelijke gegevens over beroepsopleidingen aan gebaseerd op een enquête onder alle mbo-schoolverlaters (in plaats van een steekproef) anderhalf jaar na het verlaten van de opleiding. Dit zal enkele jaren herhaald moeten worden om ook op instellingsniveau te kunnen publiceren over bijvoorbeeld de onderbenutting van opleidingen.

\subsection{Overzichten van opleidingen met laagste arbeidsmarktrelevantie}

In deze paragraaf wordt stilgestaan bij de opleidingen met de laagste arbeidsmarktrelevantie. De beoordeling van de arbeidsmarktrelevantie vindt plaats op basis van de in hoofdstuk 4 gebruikte arbeidsmarktgegevens en de daar vastgestelde grenswaardes voor het percentage werkzaam en het percentage onderbenutting een slechte beoordeling voor de arbeidsmarktrelevantie krijgen. Bij het percentage werkzaam betreft het regionale gegevens over beroepsopleidingen van het CBS (SSB), die door DUO zijn aangevuld met gegevens over het aantal deelnemers; bij het percentage onderbenutting gaat het om landelijke gegevens over beroepsopleidingen van het ROA (SIS).

\section{Percentage werkzaam}

Het percentage werkzaam heeft betrekking op het deel van de schoolverlaters dat een jaar na afstuderen voor minimaal I2 uur per week werkt. De schoolverlaters zijn tussen 2008 en 2010 afgestudeerd, waaruit door het CBS het driejaargemiddelde van het percentage werkzaam is berekend voor de jaren 2009 tot en met 201 . In tabel 5.I wordt weergegeven welke IO\% van de 2.43I bol- en bbl-beroepsopleidingen van niveau 2,3 en 4 het slechtste scoren wat betreft het percentage werkzaam. Feitelijk gaat het hier echter niet om gegevens over opleidingen maar om de totalen van de woonregio van de schoolverlaters van de betreffende opleidingen. De opleidingen in deze regio's hebben gemiddeld genomen dus een onvoldoende arbeidsmarktperspectief. Uiteraard dienen bij het toezicht en de handhaving individuele opleidingen te worden aangesproken aan de hand van de beschikbare arbeidsmarktinformatie per opleiding. De 
gegevens zouden daartoe nog verder moeten worden gedifferentieerd naar opleiding van de instelling. Voor een deel van de kleine opleidingen van onderwijsinstellingen zullen geen gegevens beschikbaar zijn vanwege de privacy-richtlijnen van het CBS. Voor deze opleidingen zou er naar de regionale of landelijke gegevens voor het percentage werkzaam kunnen worden gekeken.

Uit hoofdstuk 4 is gebleken dat bij het Ioe percentiel een grenswaarde van $67 \%$ werkzaam hoort. In tabel 5.I worden in de tweede en derde kolom de leerweg en het niveau van de opleiding aangegeven. Het betreft bijna allemaal bol-opleidingen, die redelijk gespreid zijn over de verschillende niveaus. ${ }^{32}$ De vierde kolom van de tabel bevat het aantal regio's dat onder de grenswaarde valt. Dat is meestal veel minder dan het totaal aantal arbeidsmarktregio's van 35 waarop de analyses zijn uitgevoerd. Dat komt doordat er in sommige regio's geen schoolverlaters zijn van de betreffende opleidingen, of omdat er in die regio's meer dan $67 \%$ van de schoolverlaters werkzaam is.

\section{Tabel 5.1}

Overzicht van $10 \%$ van beroepsopleidingen met het laagste percentage werkzaam, niet gecorrigeerd voor opleidingskenmerken

\begin{tabular}{|c|c|c|c|c|}
\hline Beroepsopleiding & Leerweg & Niveau & $\begin{array}{l}\text { Aantal } \\
\text { regio's }\end{array}$ & Aantal deelnemers \\
\hline Administratief medewerker & bol & 2 & 24 & 5.507 \\
\hline Artiest & bol & 4 & 3 & 629 \\
\hline Autotechniek & bol & 2 & 2 & 235 \\
\hline Commercieel medewerker & bol & 3 & 2 & 520 \\
\hline Commercieel medewerker bank- en verzekeringswezen & bol & 4 & 1 & 90 \\
\hline Dierverzorging 2 & bol & 2 & 3 & 251 \\
\hline DTP-er & bol & 3 & 2 & 122 \\
\hline Facilitaire dienstverlener & bbl & 2 & 1 & 43 \\
\hline Facilitaire dienstverlener & bol & 2 & 1 & 17 \\
\hline Financiële beroepen & bol & 2 & 1 & 1 \\
\hline Financiële beroepen & bol & 3 & 4 & 2.057 \\
\hline Frontofficemedewerker & bol & 3 & 1 & 12 \\
\hline Frontofficemedewerker & bol & 4 & 1 & 64 \\
\hline Gespecialiseerde dierverzorging gezelschapsdieren & bol & 3 & 3 & 34 \\
\hline Helpende Zorg \& Welzijn & bol & 2 & 14 & 8.920 \\
\hline ICT- en mediabeheer & bol & 4 & 2 & 304 \\
\hline ICT-medewerker & bol & 2 & 9 & 1.294 \\
\hline ICT-medewerker & bol & 3 & 12 & 2.544 \\
\hline Installeren & bol & 2 & 1 & 92 \\
\hline Interieuradviseur & bol & 4 & 2 & 224 \\
\hline Juridisch medewerker & bol & 4 & 4 & 1.594 \\
\hline Kapper & bol & 2 & 2 & 463 \\
\hline
\end{tabular}

32. Zoals eerder opgemerkt, is niveau I niet meegenomen in de analyses omdat dit niveau geen startkwalificatie voor de arbeidsmarkt biedt. 


\begin{tabular}{|c|c|c|c|c|}
\hline Kapper & bol & 3 & 1 & 19 \\
\hline Kok & bbl & 2 & 1 & 73 \\
\hline Kok & bol & 2 & 5 & 710 \\
\hline Koopvaardij officier alle schepen & bol & 4 & 1 & 192 \\
\hline Leisure \& hospitality & bol & 3 & 2 & 169 \\
\hline Leisure \& hospitality & bol & 4 & 1 & 211 \\
\hline Manager handel & bol & 4 & 3 & 876 \\
\hline Medewerker bediening/caf,-bar & bol & 2 & 2 & 230 \\
\hline Medewerker marketing en communicatie & bol & 4 & 4 & 2.011 \\
\hline Medewerker operationele techniek & bol & 2 & 1 & 104 \\
\hline Mediavormgever & bol & 4 & 11 & 4.288 \\
\hline Meubelmaker/(scheeps)interieurbouwer & bol & 2 & 2 & 146 \\
\hline Natuur en groene ruimte 4 & bol & 4 & 1 & 210 \\
\hline Ondernemer detailhandel & bol & 4 & 7 & 764 \\
\hline Onderwijsassistent & bol & 4 & 5 & 1.941 \\
\hline Particuliere beveiliging & bol & 2 & 9 & 1.279 \\
\hline Pedicure & bol & 3 & 1 & 8 \\
\hline Printmedia & bol & 4 & 1 & 11 \\
\hline Productiedieren & bol & 3 & 1 & 142 \\
\hline Productiedieren & bol & 4 & 2 & 249 \\
\hline Recreatiedieren & bol & 3 & 2 & 181 \\
\hline Reizen & bol & 3 & 1 & 67 \\
\hline Reizen & bol & 4 & 5 & 412 \\
\hline Schoonheidsspecialist & bol & 3 & 11 & 997 \\
\hline Schoonheidsspecialist & bol & 4 & 1 & 21 \\
\hline Secretariële beroepen & bol & 3 & 1 & 340 \\
\hline Secretariële beroepen & bol & 4 & 1 & 113 \\
\hline Sociaal-cultureel werker & bbl & 4 & 1 & 3 \\
\hline Sociaal-cultureel werker & bol & 4 & 8 & 866 \\
\hline Sport en bewegen & bol & 3 & 3 & 948 \\
\hline Sport en bewegen & bol & 4 & 3 & 450 \\
\hline Sport- en bewegingsbegeleider & bol & 2 & 1 & 159 \\
\hline Timmerman & bol & 2 & 1 & 105 \\
\hline Veiligheid en vakmanschap & bol & 2 & 11 & 985 \\
\hline Verkoopspecialist & bol & 3 & 6 & 1.963 \\
\hline Verkoper & bol & 2 & 19 & 4.330 \\
\hline Vormgeving ruimtelijke presentatie en communicatie & bol & 4 & 4 & 767 \\
\hline $\begin{array}{l}\text { Totaal } \\
\text { Bron: CBS/SSB, OCW/DUO }\end{array}$ & & & & 51.357 \\
\hline
\end{tabular}

De opleidingen die in meer dan de helft van de 35 arbeidsmarktregio's onder de grenswaarde vallen zijn administratief medewerker bol niveau 2 en verkoper bol niveau 2. Beide opleidingen hebben samen bijna ro.ooo deelnemers. Andere opleidingen met veel deelnemers in de verschillende regio's zijn helpende zorg \& welzijn bol niveau 2 met bijna 9.000 deelnemers, en mediavormgever bol niveau 4 met ruim 4.000 deel- 
nemers. In totaal gaat het om ruim 5 I.00o deelnemers die voor hun opleiding onder de grenswaarde van $67 \%$ van het onderste Ioe percentiel vallen. Deze jongeren nemen dus deel aan een opleiding met een lage arbeidsmarktrelevantie afgemeten aan het percentage werkzaam.

Ter vergelijking, het mbo had in 2013 ongeveer 475.000 deelnemers (excl. niveau I). Voor bijna 300.000 deelnemers in het mbo is het percentage werkzaam af te leiden uit de hier gebruikte gegevens van het CBS en DUO. Voor een significante groep van deelnemers is het niet bekend hoe het is gesteld met het percentage werkzaam van de schoolverlaters in de regio van hun opleiding. Dat komt door de privacy-richtlijnen van het CBS ten aanzien van het aantal minimum aantal werkzame schoolverlaters per opleiding (vijf), maar wellicht ook deels doordat schoolverlaters van een onderwijsinstelling verspreid over meerdere regio's woonachtig zijn. Bij de vele kleine opleidingen in het mbo, in de hier gebruikte tabellen ook nog eens opgesplitst naar bol en bbl, is er daardoor een gerede kans dat ze niet worden opgenomen in de CBS-tabellen. Bovendien kan de doorstroom van gediplomeerden naar een vervolgopleiding voor sommige mbo-opleidingen een grote rol spelen, waardoor er voor een deel van de opleidingen wel redelijk veel leerlingen zijn, maar minder dan vijf schoolverlaters. ${ }^{33}$

In de bijlage bij dit hoofdstuk worden de overzichten van opleidingen gegeven als de overige grenswaardes worden gebruikt die in tabel 4.7 van hoofdstuk 4 zijn genoemd. De aldaar eerstgenoemde grenswaarde van $80 \%$ werkzaam is als streefwaarde aangeduid. De opleidingen die deze streefwaarde niet halen zijn opgenomen in de eerste tabel in de bijlage bij hoofdstuk 5. Het aantal opleidingen in deze tabel is uiteraard veel groter dan in tabel 5.I. Het gaat om $23 \%$ van de opleidingen (i.e. opleiding-regio combinaties) met in totaal bijna I20.000 deelnemers. In de tweede tabel van de bijlage van hoofdstuk 5 zijn de slechtst scorende opleidingen opgenomen volgens de relatieve grenswaarde van het Ioe percentiel na correctie voor de opleidingskenmerken leerweg, niveau, richting en regio. De derde tabel van de bijlage bevat de opleidingen die horen bij de IO\% slechtst scorende opleidingen wat betreft zowel het ongecorrigeerde als het gecorrigeerde percentage werkzaam (zie ter verduidelijking tabel 4.2 uit het vorige hoofdstuk). Met deze combinatie van grenswaardes resteert ruim $6 \%$ van het totaal aantal opleidingen.

\section{Percentage onderbenutting}

Ook voor onderbenutting wordt inzichtelijk gemaakt welke opleidingen niet aan de grenswaarde voldoen. In hoofdstuk 4 is aangegeven dat de grenswaarde van $52 \%$ samenhangt met het aandeel van IO\% van de opleidingen met het hoogste percentage onderbenutting. Aan deze grenswaarde wordt hier de voorkeur gegeven, mede omdat deze aansluit bij de praktische norm van IO\% die door de Inspectie van het Onderwijs al wordt gehanteerd (zie verder hoofdstuk 4).

33. Zie verder paragraaf 5.4 over de doorstroom. 
In tabel 5.2 is de groep van IO\% van de beroepsopleidingen weergegeven met het hoogste percentage onderbenutting onder schoolverlaters anderhalf jaar na afstuderen. In tegenstelling tot de vorige vier tabellen zijn deze gegevens niet van het CBS (SSB) afkomstig maar van het ROA (SIS). Het betreft geen administratieve gegevens maar enquêtegegevens. Bovendien bevat tabel 5.2 landelijke gemiddeldes over vijf jaar, zonder dat er onderscheid is gemaakt tussen bol en bbl. Uit het aantal respondenten blijkt dat een verdergaande uitsplitsing naar leerweg, regio of onderwijsinstellingen nauwelijks mogelijk is. Het valt op dat de opleidingen voor meer dan de helft bblgeoriënteerd zijn in de richtingen landbouw, techniek en economie, en dat niveau 3 sterk is oververtegenwoordigd. Dit sluit aan bij de bevindingen in paragraaf 4.4 uit het vorige hoofdstuk. De score van het Ioe percentiel is $52 \%$, zodat alle opleidingen in de tabel een onderbenutting van $52 \%$ of hoger hebben. Uiteraard kan deze percentielscore enigszins veranderen over de tijd.

Tabel 5.2

Beroepsopleidingen die de tot onderste $10 \%$ behoren met het percentage onderbenutting, gemiddelde 2007-2011

\begin{tabular}{lcccc|}
\hline Beroepsopleiding & bbl & Niveau & $\begin{array}{c}\text { Aantal } \\
\text { respondenten }\end{array}$ & $\begin{array}{c}\text { Onderbenutting } \\
\%\end{array}$ \\
\hline Meubelmaker/ (scheeps)interieurbouwer & $\%$ & & 25 & 75 \\
\hline Toezicht en veiligheid & 84 & 3 & 70 & 75 \\
\hline Medewerker schilderen & 9 & 2 & 22 & 71 \\
\hline Logistiek teamleider & 100 & 3 & 22 & 68 \\
\hline Metaalbewerken & 92 & 3 & 38 & 65 \\
\hline Bedrijfsautotechniek & 100 & 3 & 24 & 63 \\
\hline Machinist & 100 & 3 & 45 & 62 \\
\hline Metselaar & 100 & 3 & 25 & 54 \\
\hline Veiligheid en vakmanschap & 100 & 3 & 63 & 54 \\
\hline Gespecialiseerde dierverzorging gezelschapsdieren & 11 & 2 & 51 & 53 \\
\hline Verkoper & 73 & 2 & 215 & 53 \\
\hline Bloemendetailhandel & 53 & 3 & 55 & 52 \\
\hline Timmerman & 100 & 3 & 130 & 52
\end{tabular}

Bron: ROA/SIS, OCW/DUO

\subsection{Aanvullingen op het beoordelingskader}

Als opleidingen niet voldoen aan de vastgestelde grenswaardes voor het percentage werkzaam of onderbenutting, zijn onderwijsinstellingen aan zet om te laten zien dat hun opleidingen toch een hogere arbeidsmarktrelevantie hebben dan in eerste instantie uit de eerste inventarisatie blijkt, of om op omstandigheden te wijzen die een (tijdelijke) onvoldoende arbeidsmarktrelevantie kunnen rechtvaardigen. Aan de hand van zowel kwantitatieve als kwalitatieve indicatoren van het ROA, SBB of uit eigen enquêtes of van andere onderzoeksbureaus, kunnen wellicht de arbeidsmarktrelevantie van de betreffende opleidingen onderbouwd worden. Het is aan de handhaver 
te beoordelen of er voldoende aanleiding is om zijn oordeel bij te stellen. Voorbeelden van deze indicatoren zijn opgenomen in tabel 5.3. Een uitgebreide bespreking en weergave van een deel van deze indicatoren is terug te vinden in een aantal publicaties over macrodoelmatigheid van het ROA (Bertrand-Cloodt, 2013; ROA, 2013a, hoofdstuk 4; Clerx et al., 2OI4), en in de publicaties over 'Kans op werk' en 'Kans op stage' van de diverse kenniscentra die aan het SBB zijn gelieerd (zie www.s-bb.nl).

Zoals in hoofdstuk 4 al is gesteld dient voor een verantwoord gebruik van de arbeidsmarktprognoses van het ROA (ITA) en SBB (Kans op werk) in de beoordeling van de arbeidsmarktrelevantie en handhaving nog een kwaliteitsslag te worden gemaakt, hetzij in de mate van detail hetzij in de methodiek en transparantie. Toch kan er naar deze indicatoren al worden gekeken als er wat dieper wordt ingegaan op de arbeidsmarktrelevantie, en verschillende elementen ervan tegen elkaar op een meer kwalitatieve wijze worden afgewogen. Voor andere indicatoren (spijt, werkloosheid, werkzaam in eigen richting) die in tabel 5.3 zijn opgenomen is in hoofdstuk 3 aangetoond dat ze sterk gecorreleerd zijn met het percentage werkzaam van het CBS. Dat neemt niet weg dat er bij opleidingen toch verschillen kunnen bestaan tussen de diverse indicatoren voor arbeidsmarktrelevantie. De correlaties zijn immers gebaseerd op statistische patronen voor het totaal van opleidingen in de gebruikte steekproef of populatie. Het is voorstelbaar dat er opleidingen zijn die een laag percentage werkzaam hebben maar toch goed scoren op andere indicatoren. Uiteraard moet dan worden nagegaan wat er precies aan de hand is met de betreffende opleidingen.

Tabel 5.3

Voorbeelden van aanvullende kwantitatieve indicatoren voor de arbeidsmarktrelevantie van opleidingen

\begin{tabular}{ll}
\hline Indicator & Meting \\
\hline Indicator Toekomstig Arbeidsmarktperspectief (ITA) & ROA \\
\hline Kans op werk (in het verlengde van de opleiding) & SBB \\
\hline Werkloosheid & ROA \\
Spijt van de opleiding & ROA \\
Werkzaam in eigen richting & ROA \\
\hline Werkzaam in eigen regio & ROA, CBS \\
\hline Kans op stage & SBB \\
\hline Doorstroom naar vervolgopleiding & DUO, CBS
\end{tabular}

Tot slot is het van belang om te kijken naar het belang van de doorstoom van de gediplomeerden van een opleiding naar een vervolgopleiding in het mbo of hbo. Niet alle gediplomeerden zullen als schoolverlater op de arbeidsmarkt instromen. Een groot deel van de mbo-gediplomeerden stroomt binnen het mbo door naar een vervolgopleiding van meestal hoger niveau (zie ROA, 2013b). Dit betreft ca. 23\% voor zowel bol- als bbl-gediplomeerden van niveau I $\mathrm{t} / \mathrm{m}$ 4. Van de bol-gediplomeerden (meestal niveau 4) stroomt nog $30 \%$ door naar een hbo-opleiding. Dat betekent dat $44 \%$ van de bol-gediplomeerden en $76 \%$ van de bbl-gediplomeerden niet deelnemen aan een 
kwalificerend vervolgtraject in het onderwijs en in principe beschikbaar zijn voor de arbeidsmarkt.

Opleidingen die evident een doorstroomfunctie hebben, dienen wellicht niet al te zwaar te worden beoordeeld op de arbeidsmarktrelevantie. Het is mogelijk dat er voor gediplomeerden van doorstroomopleidingen die toch een baan gingen zoeken weinig banen beschikbaar waren, of dat zij de zwakkere leerlingen waren die niet in het gebruikelijke vervolgonderwijs voor deze opleidingen zijn gaan deelnemen. Uit onze analyses met de in dit rapport gebruikte CBS- en DUO-gegevens, blijkt inderdaad dat opleidingen met een grotere doorstroom naar vervolgonderwijs een lager percentage werkzaam hebben. ${ }^{34}$

Als de situatie dreigt dat onderwijsinstellingen niet kunnen voldoen aan de zorgplicht arbeidsmarktperspectief vanwege een gebrekkige arbeidsmarktrelevantie van één of meerdere van de door hen aangeboden opleidingen, kan er tevens worden teruggegrepen op een aantal meer kwalitatieve indicatoren. De handhaver geeft een voorlopig oordeel dat aan het management van de betreffende instellingen wordt voorgelegd. Het management wordt om reactie gevraagd op de scores van verschillende indicatoren. Het eerder gehouden onderzoek van de Inspectie van het Onderwijs (20I0) kan hierbij als voorbeeld dienen. Tabel 5.4 presenteert een overzicht van mogelijke kwalitatieve indicatoren gericht op zowel het resultaat als het proces van afstemming tussen de handhaver en de onderwijsinstelling.

Tabel 5.4

Kwalitatieve indicatoren voor de zorgplicht arbeidsmarktperspectief als de arbeidsmarktrelevantie van opleidingen onvoldoende is, proces en resultaten

\begin{tabular}{|c|c|}
\hline Indicator & Meting \\
\hline Onvoorziene omstandigheden (resultaten) & $\begin{array}{l}\text { Op handen zijnde uitbreidingen van bedrijven of instellingen, regionale } \\
\text { investeringsagenda's, sectorplannen }\end{array}$ \\
\hline Besef bij management (proces) & Interne rapportages, jaarverslag \\
\hline $\begin{array}{l}\text { Overleg met stakeholders zoals werkgevers, } \\
\text { gemeentes en UWV (proces) }\end{array}$ & Verslaglegging van bijeenkomsten \\
\hline Reeds genomen maatregelen (resultaten) & $\begin{array}{l}\text { Informatiemateriaal en brochures voor studiekiezers, afbouw van } \\
\text { opleidingen, 'baangaranties'van werkgevers }\end{array}$ \\
\hline
\end{tabular}

34. Het verband is sterk statistisch significant. Het verband kan overigens ook andersom worden verklaard: een geringe kans op een baan, gemeten door een laag percentage werkzaam, kan een toename van de doorstroom naar vervolgonderwijs veroorzaken. Zo zijn er aanwijzingen dat gediplomeerden bij een verslechtering van de conjunctuur vaker deelnemen aan vervolgonderwijs (zie bijvoorbeeld CPB, 2OII). 


\subsection{Conclusies}

Bij de invulling van het beoordelingskader van de arbeidsmarktrelevantie van opleiding dient er in ieder geval een duidelijke procedure te worden gehanteerd. In dit hoofdstuk is daartoe een voorzet gedaan. De eerste stap is de inventarisatie van opleidingen die niet voldoen aan de grenswaarde voor het percentage werkzaam of het percentage onderbenutting. De grenswaardes die als meest voor de hand liggend uit hoofdstuk 4 naar voren zijn gekomen, hebben betrekking op de score van het ${ } \mathrm{O}^{\mathrm{e}}$ percentiel in de rangorde van opleiding naar percentage werkzaam (i.e. 67\%) en percentage onderbenutting (i.e. 52\%). Uiteraard kunnen de absolute grenswaardes die bij het $\mathrm{IO}^{\mathrm{e}}$ percentiel horen veranderen over de tijd. In dit hoofdstuk zijn voor de genoemde grenswaardes de opleidingen weergegeven die niet voldoen aan de grenswaarde. Verder zijn er in de bijlage van dit hoofdstuk nog de tabellen met opleidingen opgenomen als de overige genoemde grenswaardes voor percentage werkzaam uit hoofdstuk 4 worden gehanteerd.

Als opleidingen niet voldoen aan de vastgestelde grenswaardes voor het percentage werkzaam of onderbenutting, zijn onderwijsinstellingen aan zet om hier uitleg aan te geven en om te laten zien dat er andere kwantitatieve of kwalitatieve indicatoren zijn die op het tegendeel wijzen of laten zien dat er verzachtende omstandigheden zijn. Deze indicatoren kunnen zowel harde indicatoren zijn die een ander licht laten schijnen over de arbeidsmarktsituatie van de betreffende opleidingen, als kwalitatieve indicatoren die bijvoorbeeld laten zien welke maatregelen zijn genomen en hoe de afstemming met stakeholders door de onderwijsinstelling al in gang is gezet. Het is aan de handhaver om te beoordelen of er voldoende aanleiding is om zijn oordeel bij te stellen, en eventuele verdergaande maatregelen te nemen.

Het voorstel voor inkadering in dit rapport dient mede in het licht te worden gezien van een leerproces. Het is dus van belang eenvoudig te beginnen en regelmatig te evalueren. Daarbij dienen waar mogelijk de gegevensverzameling over opleidingen, de (prognose)methodiek en het toezicht op de zorgplicht arbeidsmarktperspectief in de loop der tijd uitgebreid en verfijnd te worden. Zodoende kan er ervaring worden opgebouwd met de verschillende indicatoren van arbeidsmarktperspectief. Ook kan na enkele jaren een betere inschatting worden gemaakt van het belang van het onverwachts optreden van nieuwe situaties. Veranderingen in de economische conjunctuur, de regionale arbeidsvraag of de populariteit van specifieke opleidingen kunnen immers grote invloed hebben op de arbeidsmarktpositie van opleidingen zonder dat dit tijdig kan worden voorzien. Verder is het niet uit te sluiten dat onderwijsinstellingen in de loop der jaren veel beter naar de arbeidsmarktrelevantie van opleidingen gaan kijken, waardoor er op den duur minder opleidingen zijn met een slecht arbeidsmarktperspectief. Indien deze situatie zou optreden, kan de interventie door middel van het aanscherpen van de zorgplicht arbeidsmarktperspectief uiteraard als succesvol worden beschouwd, maar noopt dat wellicht tevens tot het aanpassen van de (relatieve) grenzen. 
Wat betreft de gegevensverzameling over opleidingen is in dit en het vorige hoofdstuk gebleken dat er diverse verbeterpunten zijn in de gegevensverzameling om een beter zicht te krijgen op de macrodoelmatigheid van mbo-opleidingen:

- Wat betreft onderbenutting dienen de gegevens over opleidingen op instellingsniveau te kunnen worden uitgesplitst. Het ROA zal dit jaar schoolverlatersgegevens over het mbo publiceren gebaseerd op een integrale enquête van (vrijwel) alle schoolverlaters van het mbo anderhalf jaar na afstuderen. Als dit enkele jaren wordt herhaald kunnen er meerjarige gemiddeldes over de onderbenutting van opleidingen op instellingsniveau worden gepubliceerd.

- Voor alle indicatoren is er extra aandacht nodig voor de arbeidsmarktrelevantie van kleine opleidingen. Deze kunnen vaak nauwelijks op instellingsniveau worden waargenomen omdat er te weinig schoolverlaters zijn om te kunnen publiceren over het percentage werkzaam of onderbenutting volgens de richtlijnen van het CBS of het ROA. Deze opleidingen dienen derhalve breder te worden gedefinieerd, of op regionaal of landelijk niveau in plaats van instellingsniveau te worden waargenomen.

- Er dient voor een verantwoord gebruik van de arbeidsmarktprognoses van het ROA (ITA) en SBB (Kans op werk) in de beoordeling van de arbeidsmarktrelevantie en handhaving nog een kwaliteitsslag te worden gemaakt, hetzij in de mate van detail hetzij in de methodiek en transparantie.

- Tot slot dient er ook meer inzicht te worden verkregen in de doorstroom van vooral bol-gediplomeerden in het vervolgonderwijs. Bij het beoordelen van de doelmatigheid van opleidingen die vooral dienen voor de doorstroom binnen het mbo of naar het hbo, ligt het meer voor de hand dat deze opleidingen beoordeeld worden op het succes in de vervolgopleiding dan op de arbeidsmarktrelevantie. 



\section{Conclusies}

Dit rapport bevat een onderzoek naar een beoordelingskader voor de arbeidsmarktrelevantie van opleidingen. De arbeidsmarktrelevantie is een dimensie van de 'macrodoelmatigheid' van het opleidingenaanbod, naast de andere twee dimensies doelmatigheid (kostenefficiëntie, kwaliteit en continuïteit) en toegankelijkheid voor jongeren (bereikbaarheid en toelating). Het voorliggende onderzoek over de arbeidsmarktrelevantie van opleidingen is uitgevoerd in het kader van de zogeheten zorgplicht arbeidsmarktperspectief die onderwijsinstellingen hebben.

Een goede aansluiting met de arbeidsmarkt is van belang voor jongeren die een opleiding hebben afgerond, maar ook voor werkgevers uit het bedrijfsleven en bij de overheid. Vooral door werkloosheid maar ook door mismatch op de arbeidsmarkt (horizontaal of verticaal) ontstaan er grote productiviteitsverliezen bij de arbeidsmarktintrede. Bovendien zijn de effecten van werkloosheid bij de arbeidsmarktintrede verderop in de loopbaan van schoolverlaters terug te vinden doordat er een grotere kans op hernieuwde werkloosheid is of een lager loon wordt verdiend ('scarring').

Uit de analyses in dit rapport komt naar voren dat de arbeidsmarktrelevantie van beroepsopleidingen beoordeeld kan worden op twee indicatoren over de intrede van schoolverlaters op de arbeidsmarkt:

- Percentage werkzaam van het CBS;

- Percentage onderbenutting van het ROA.

De eerste indicator blijkt sterk te correleren met allerlei andere aansluitingsindicatoren, waaronder werkloosheid, spijt van de opleidingen, werken buiten richting. Bovendien is deze indicator het gemakkelijkste op instellingsniveau te genereren omdat er gebruik kan worden gemaakt van administratieve gegevens. De indicator onderbenutting geeft in aanvulling hierop nog extra informatie over de aansluiting. Het nadeel van deze indicator is echter dat er op instellingsniveau nog niet voldoende betrouwbare gegevens beschikbaar zijn.

De literatuur geeft weinig aanknopingspunten voor grenswaardes van opleidingen waaraan onderwijsinstellingen zouden moeten voldoen wat betreft het percentage werkzaam en het percentage onderbenutting. Bij de keuze voor de grenswaardes is in dit rapport rekening gehouden met de volgende kenmerken die grenswaardes bij voorkeur zouden moeten hebben: 
- Probleemgericht;

- Realistisch;

- Eenvoudig;

- Robuust.

Wat betreft de probleemgerichtheid, is het duidelijk dat een laag percentage werkzaam en/of een hoog percentage onderbenutting een potentieel probleem weergeeft voor de arbeidsmarktrelevantie. Realistische grenswaardes zetten onderwijsinstellingen aan tot maatregelen om de arbeidsmarktrelevantie van opleidingen te verbeteren. Gemiddelde percentages over alle opleidingen kunnen als streefwaardes worden beschouwd, maar zijn niet zo realistisch om te handhaven omdat er veel opleidingen zijn die een grenswaarde gebaseerd op een gemiddelde niet halen. Een absoluut percentage als grenswaarde is echter eenvoudig toe te passen, en wordt tevens wat robuuster, i.e. minder afhankelijk van de conjunctuur of toevallige uitschieters, als er over meerdere jaren wordt gemiddeld.

De grensbepaling wordt relatief genoemd als ze is gebaseerd op bijvoorbeeld Io\% of $20 \%$ van de slechtst scorende opleidingen. Relatieve grenzen zijn realistisch omdat het plausibel is dat er bij de slechtst scorende opleidingen een verbeterslag kan worden gemaakt. Onderwijsinstellingen weten dan echter minder goed waar ze aan toe zijn dan bij een absolute grenswaarde, omdat de relatieve grenswaarde mede afhankelijk is van hoe andere onderwijsinstellingen scoren op de indicatoren voor de arbeidsmarktrelevantie. Correcties voor de kenmerken van de opleidingen (leerweg, niveau, richting, regio) maken dat de grenswaardes realistischer worden maar minder eenvoudig toe te passen, omdat er statistische schattingen nodig zijn die bovendien niet altijd robuust zijn.

In dit onderzoek zijn de volgende drie methodes uiteengezet om tot een grenswaarde te komen voor het percentage werkzame schoolverlaters.

- Methode I - Absolute grensbepaling: Gerelateerd aan gegevens over de beroepsbevolking zou heel rudimentair gesteld een gemiddelde van $80 \%$ werkzaam voor mbo-schoolverlaters, zelfs in slechte economische tijden, haalbaar moeten zijn. Een grenswaarde die bedoeld is om een potentieel problematische situatie in kaart te brengen, moet echter aanmerkelijk lager liggen.

- Methode 2 - Relatieve grensbepaling zonder correcties: Hier is gekeken naar de IO\% opleidingen met het laagste aandeel werkenden. De grenswaarde behorende bij het $\mathrm{IO}^{\mathrm{e}}$ percentiel is $67 \%$ voor opleidingen gedifferentieerd naar leerweg, niveau, richting, regio.

- Methode 3 - Relatieve grensbepaling met correcties: Ook hier is gekeken naar de IO\% opleidingen met het laagste aandeel werkenden, waarbij gecorrigeerd is voor de kenmerken van de opleiding (leerweg, niveau, richting en regio). Ondanks deze correcties is er een grote overlap met de IO\% slechtst scorende opleidingen van methode 2 . 
Uit verschillende analyses op grond van zowel landelijke als regionale gegevens blijkt dat een benchmark van gemiddeld ongeveer $70 \%$ werkzaam voor opleidingen een redelijk uitgangspunt is voor een grenswaarde. Hierbij worden driejaarsgemiddeldes gebruikt van het percentage werkzaam van het CBS. Het gaat om werk van minimaal I2 uur per week van mbo-schoolverlaters een jaar na afstuderen in de periode 200920II. De hier gebruikte gegevens over beroepsopleidingen (i.e. clusters van creboopleidingen volgens de bestaande koppeltabel) zijn geaggregeerd naar regio, maar wel uitgesplitst naar leerweg. In totaal gaat het om ruim 50.000 deelnemers die een opleiding volgen met een aandeel werkzame schoolverlaters dat tot de onderste Io\% van de verdeling behoort. Dit is ca. een zesde van het aantal deelnemers aan opleidingen waarvoor gegevens over het percentage werkzaam beschikbaar zijn.

Ook bij het percentage onderbenutting kan er een grenswaarde worden gehanteerd. Om de grenswaarde vast te stellen, zijn twee methodes uiteengezet.

- Methode I - Absolute grensbepaling: Op basis van gegevens uit de beroepsbevolking zou $40 \%$ onderbenutting als uitgangspunt kunnen gelden. In de landelijke statistische verdeling gebaseerd op de ROA-schoolverlatersenquêtes (SIS) gaat het dan om $23 \%$ van de opleidingen.

- Methode 2 - Relatieve grensbepaling: Om precies IO\% van de slechtst scorende opleidingen te identificeren, moet de grenswaarde op $52 \%$ onderbenutting worden vastgesteld.

De grenswaardes die ons inziens als meest voor de hand liggend naar voren komen, hebben betrekking op het ongecorrigeerde meerjaarsgemiddelde van het $\mathrm{I}^{\mathrm{e}}$ percentiel in de rangorde van opleidingen naar percentage werkzaam (i.e. maximaal 67\%) of percentage onderbenutting (i.e. minimaal $52 \%$ ). Uit de relatieve grensbepaling volgt een absolute ondergrens die in de communicatie, mits stabiel door de jaren heen, goed gebruikt kan worden. De relatieve grenswaarde van IO\% is tevens een praktische norm die bij het toezicht door de Inspectie van het Onderwijs al vaak wordt gehanteerd. Uiteraard kunnen de absolute grenswaardes die bij het ${ }_{10}{ }^{e}$ percentiel horen veranderen over de tijd.

Welke grenswaardes voor opleidingen uiteindelijk worden vastgesteld, hangt tevens van de ambities af van de diverse betrokken instanties zoals onderwijsinstellingen en het ministerie. In dat opzicht kan er een parallel getrokken worden met de aanpak van voortijdig schoolverlaters (vsv). De vsv-aanpak laat zien dat het vaststellen van doelen of grenswaardes vooral een kwestie van ambitie is, die samenhangt met hoe urgent een probleem wordt ervaren en de inspanningen die men wil plegen om de situatie te verbeteren. De urgentie van het probleem wordt duidelijk door de schadelijke effecten onder ogen te zien van het voortijdig schoolverlaten of van een slechte arbeidsmarktrelevantie van opleidingen. In dit rapport is gewezen op het productiviteitsverlies door een slechte arbeidsmarktintrede van schoolverlaters, en eventuele 'scarring' effecten later in de loopbaan. 
Het is vanzelfsprekend een voordeel als ook het onderwijsveld zich kan vinden in de indicatoren die instellingen ertoe moeten aanzetten om het arbeidsmarktperspectief van opleidingen te verbeteren. Het verder uitwerken van een beoordelingskader is een leerproces waaraan alle belanghebbenden een steentje moeten bijdragen. Het voorstel voor inkadering van het arbeidsmarktperspectief in dit rapport dient mede in het licht te worden gezien van dat leerproces. Het is van belang eenvoudig te beginnen en regelmatig te evalueren. Er moet bij het opstellen van een beoordelingskader veel aandacht worden besteed aan het opbouwen van ervaring met de arbeidsmarktgegevens, zowel door het Ministerie van OCW en de handhaver als de onderwijsinstellingen. Bovendien dient er aanvullende gegevensverzameling plaats te vinden, en moet er ervaring worden opgedaan met kwalitatieve indicatoren en het proces van afstemming tussen onderwijsinstellingen onderling en met de diverse belanghebbenden.

Wat betreft de gegevensverzameling over de arbeidsmarktrelevantie van opleidingen, zijn er diverse verbeterpunten te noemen, waarvoor deels al maatregelen genomen zijn:

- Wat betreft onderbenutting is er aanvullende gegevensverzameling in gang gezet, waardoor er voor deze indicator gepubliceerd kan worden over opleidingen op instellingsniveau;

- Voor een verantwoord gebruik van arbeidsmarktprognoses in het beoordelingskader is het voornemen gemaakt om de kwaliteit van deze prognoses te verbeteren, zowel in de mate van detail als in de methodiek en transparantie;

- De arbeidsmarktrelevantie kan voor kleine opleidingen nauwelijks op instellingsniveau worden waargenomen. Deze opleidingen dienen derhalve breder te worden gedefinieerd, of op regionaal of landelijk niveau in plaats van instellingsniveau te worden waargenomen;

- Meer inzicht in de betekenis van de doorstroom van vooral bol-gediplomeerden in het vervolgonderwijs is gewenst. Als er veel doorstroom is, ligt het voor de hand om bij de beoordeling van de opleiding het succes in de vervolgopleiding een belangrijke plaats te geven naast de arbeidsmarktrelevantie.

Bij het toezicht op de zorgplicht arbeidsmarktperspectief kan er in de loop der jaren ervaring worden opgebouwd met de verschillende indicatoren van arbeidsmarktrelevantie. Er kan dan tevens een betere inschatting worden gemaakt van het belang van het onverwachts optreden van nieuwe situaties zoals veranderingen in de economische conjunctuur, de regionale arbeidsvraag of de populariteit van specifieke opleidingen. Bovendien is het denkbaar dat onderwijsinstellingen in de loop der jaren beter naar de arbeidsmarktrelevantie van hun opleidingenaanbod gaan kijken, waardoor er op den duur minder opleidingen zijn met een slecht arbeidsmarktperspectief. Indien deze situatie zou optreden, kan de interventie door middel van het aanscherpen van de zorgplicht arbeidsmarktperspectief uiteraard als succesvol worden beschouwd, maar noopt dat wellicht tevens tot het aanpassen van het beoordelingskader. 


\section{Literatuur}

Bertrand-Cloodt, D. (2010), Evaluatie uitbreidingsvraag en indicator toekomstig arbeidsmarktperspectief (ITA) tot 2008, ROA-TR-2010/6, Maastricht University.

Bertrand-Cloodt, D., F. Cörvers, H. Heijke, J. van Thor (2011), Verkenning van de invloed van reisafstand op de keuze voor een middelbare beroepsopleiding, ROA-TR-2011/1, Maastricht University.

Clerx, R., F. Cörvers, D. Fouarge (2014), Regionale arbeidsmarktprognoses 2013-2018, methodiek en resultaten, ROA-TR-2014/2, Maastricht University.

Coenen, J., F. Cörvers, D. Fouarge, C. Meng, A. Nelen (2009), Onderbenutting van mbo'ers nuttig op de arbeidsmarkt?, TPEdigitaal, Vol. 3, pp. 103-123.

Commissie Macrodoelmatigheid Amarantis (2013), Slimmer samen, 19 juni.

CPB (2011), Relatie conjunctuur en onderwijsdeelname, Een literatuurstudie, power point presentatie Adviescommissie Leerlingen- en Studentenramingen 29 november, Den Haag.

Dupuy, A. (2009), An evaluation of the forecast of the indicator of the labour market gap, ROATR-2009/3, Maastricht University.

Eimers, T. (2012), Afwegingskader regionaal/sectoraal opleidingenaanbod mbo, Kenniscentrum Beroepsonderwijs Arbeidsmarkt (KBA), Nijmegen.

Fouarge, D. (2009), Macro-economische shocks: Gevolgen op korte en lange termijn, in: ROA (2009), Schoolverlaters tussen onderwijs en arbeidsmarkt 2008, ROA-R-2009/4, Maastricht University, pp. 47-63

Grip de, A, H. Boxma, D. Willems, M. Boxtel (2008), Job-Worker Mismatch and Cognitive Decline, Oxford Economic Papers, Vol. 60, pp. 237-253.

Heckman J., G. Borjas (1980), Does unemployment cause future unemployment? Definitions, questions and answers from a continuous time model of heterogeneity and state dependence, Economica, Vol. 47, 247-283.

Heijke, H., Meng, C., Ris, C. (2003), Fitting to the Job: the role of generic and vocational competencies in adjustment and performance, Labour Economics, Vol. 10, pp. 215-229.

Inspectie van het Onderwijs (2010), Zorgplicht arbeidsmarktperspectief bij mbo-instellingen. Resultaten van een verkennend onderzoek naar de relatie tussen het opleidingen-en informatieaanbod aan deelnemers en de arbeidsmarkt, januari, Utrecht.

Inspectie van het Onderwijs (2012), Toezichtkader, Beroepsonderwijs en volwasseneneducatie 2012, Uitgangspunten, Werkwijze, Waarderingskader, Utrecht.

Inspectie van het Onderwijs (2014), De staat van het onderwijs, Onderwijsverslag 2012/2013, 16 april, Utrecht.

Meng, C. (2006), Discipline-Specific or Academic? Acquisition, Role and Value of Higher Educa- 
tion Competencies, ROA Dissertations Nr. 6, Maastricht University.

Ministerie van OCW (2011), Actieplan mbo 'Focus op Vakmanschap 2011-2015', Brief aan de Tweede Kamer, 16 februari, Den Haag.

Ministerie van OCW (2012), Brief van de minister van Onderwijs, Cultuur en Wetenschap, Brief aan de Tweede Kamer, 2 juni, kst-31524-129, Den Haag.

Ministerie van OCW (2013), Briefvan de minister van Onderwijs, Cultuur en Wetenschap, Brief aan de Tweede Kamer, 14 april, kst-31524-166, Den Haag.

Ministerie van OCW (2013a), Brief van de minister van Onderwijs, Cultuur en Wetenschap, Brief aan de Tweede Kamer, 7 oktober, kst-31524-184, Den Haag.

Ministerie van OCW (2013b), Brief van de minister van Onderwijs, Cultuur en Wetenschap, Brief aan de Tweede Kamer, Aanpak voortijdig schoolverlaten, Referentie 485099, 12 februari, Den Haag.

Ministerie van OCW (2014), Briefvan de minister van Onderwijs, Cultuur en Wetenschap, Brief aan de Tweede Kamer, Nieuwe cijfers over terugdringen voortijdig schoolverlaters, Referentie 586602, 15 januari, en Bijlagen Uitvalcijfers mbo en Uitvalcijfers RMC-regio's, Den Haag.

Mooi-Reçi, I. (2008), Unemployed and scarred for life? Longitudinal analyses of how unemployment and policy changes affect re-employment careers and wages in the Netherlands, 19802000, Academisch Proefschrift, Vrije Universiteit Amsterdam.

Mroz, T., T. Savage (2006), The long-term effects of youth unemployment, Journal of Human Resources, Vol. 41, pp. 259-293.

Onderwijsraad (2012), Zicht op een macrodoelmatig onderwijsaanbod, Advies aan de Tweede Kamer, juni, Den Haag.

ROA (2011), Depreciatie van menselijk kapitaal, ROA-R-2011/1, Maastricht University.

ROA (2013), Arbeidsmarktrelevantie van grote MBO-opleidingen, ROA-F-2013/1, Maastricht University.

ROA (2013a), De arbeidsmarkt naar opleiding en beroep tot 2018, ROA-R-2013/11, Maastricht University.

ROA (2013b), Schoolverlaters tussen onderwijs en arbeidsmarkt 2012, ROA-R-2013/7, Maastricht University.

Schils, T., D. Fouarge, M. Kerkhofs (2006), Loon en werk na werkloosheid, OSA-rapport A221, Tilburg.

SBB (2014), Kans op werk, Veel gestelde vragen over Kans op werk, versie 30 januari 2014, Zoetermeer.

Vink, R., M. Oosterling, M. Vermeulen, T. Eimers, R. Kennis (2010), Doelmatigheid van het middelbaar beroepsonderwijs, IVA beleidsonderzoek en advies in samenwerking met Kenniscentrum Beroepsonderwijs Arbeidsmarkt (KBA), Tilburg/Nijmegen.

Wachter, T. von, S. Bender (2006), In the right place at the wrong time: the role of firms and luck in young worker's careers, American Economic Review, Vol. 96, pp. 1679-1705.

Werfhorst, H.G. van de (2002), Fields of study, acquired skills and the wage benefit from a matching job, ACTA Sociologica, Vol. 45, pp. 287-303. 


\section{Bijlage tabellen hoofdstuk 3}




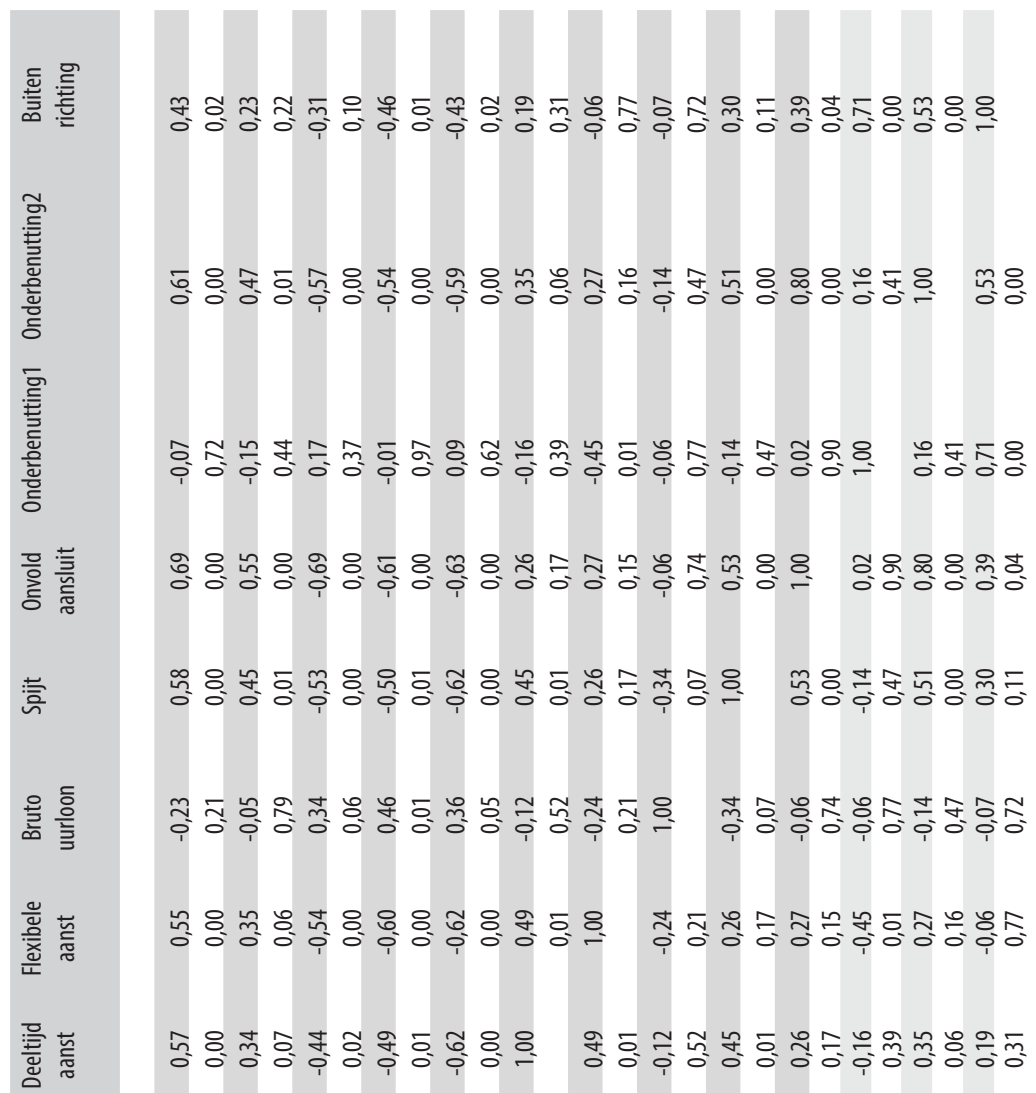

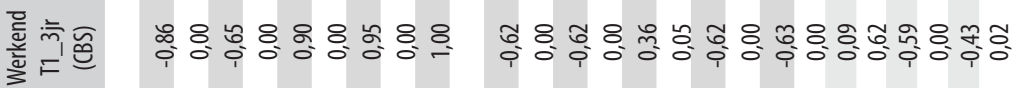

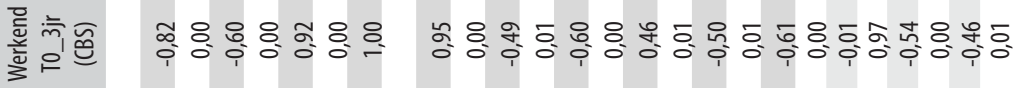

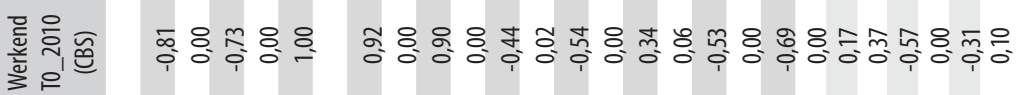

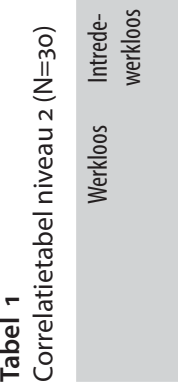

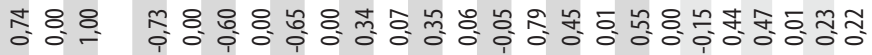

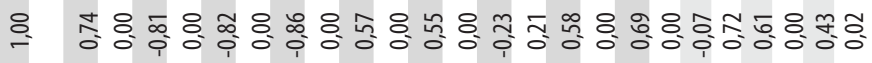

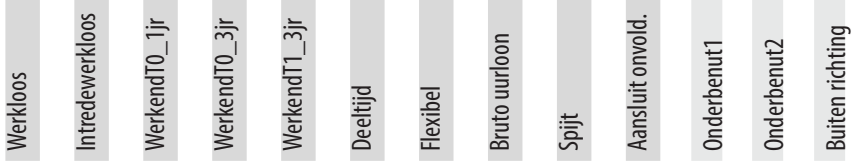




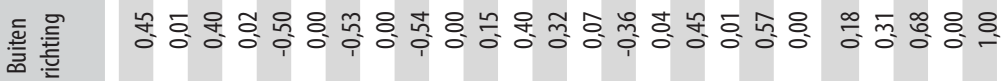

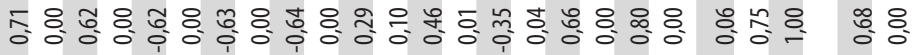

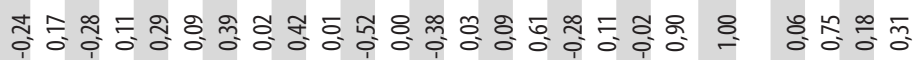

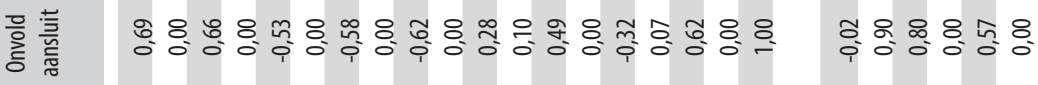

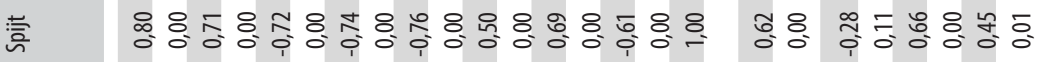

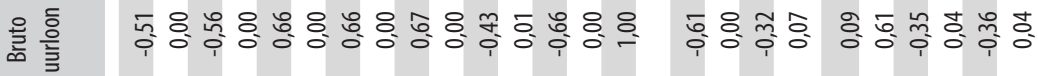

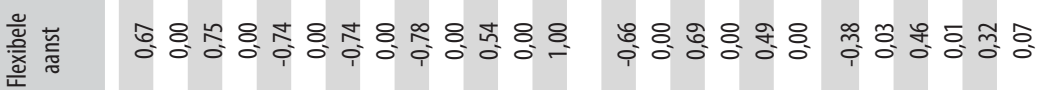

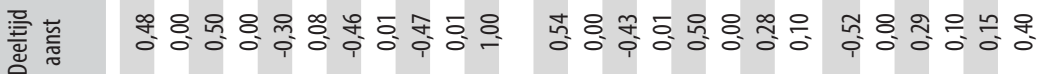

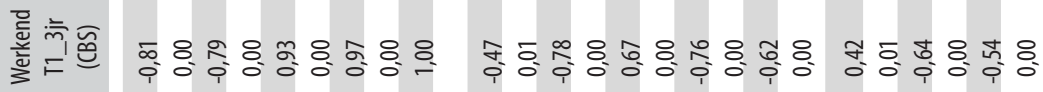

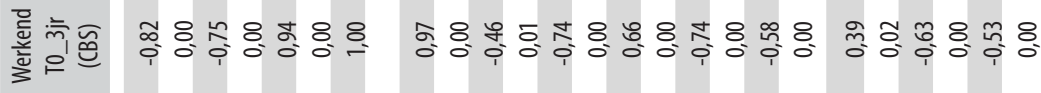

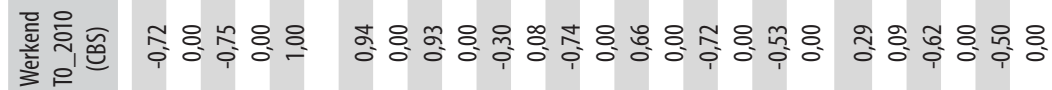

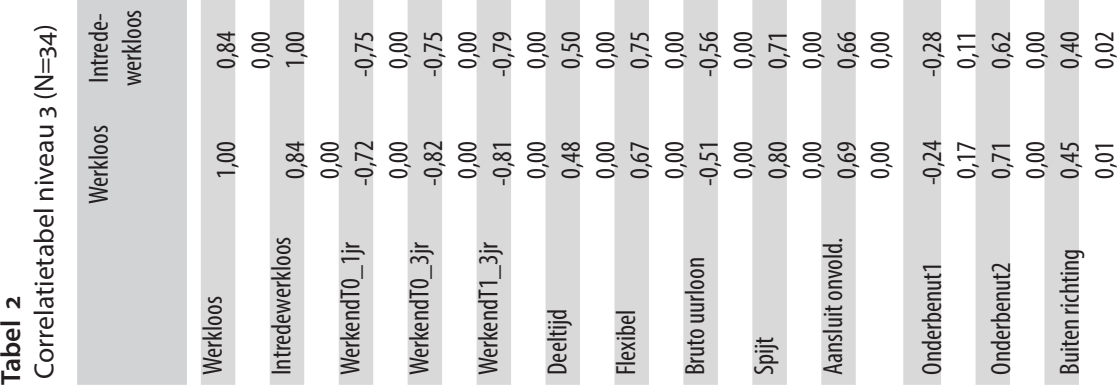




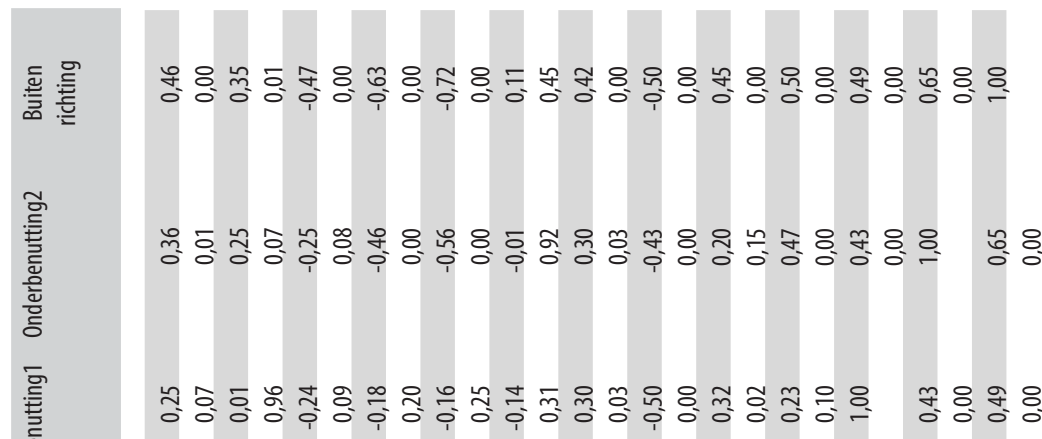

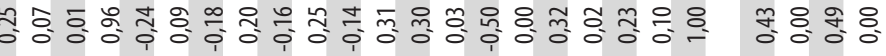

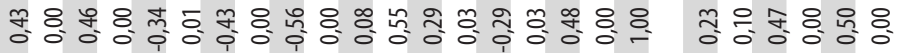

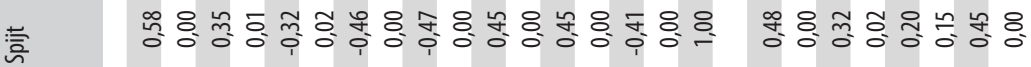

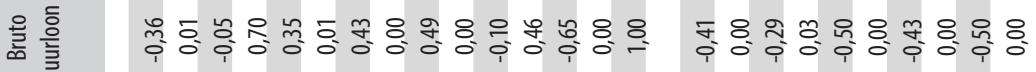

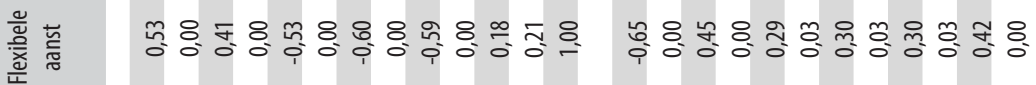

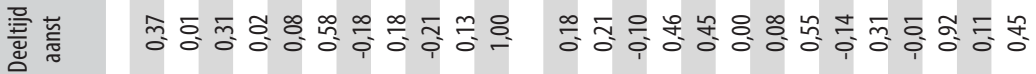

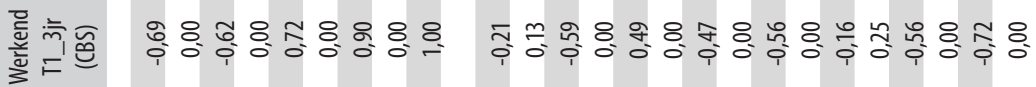

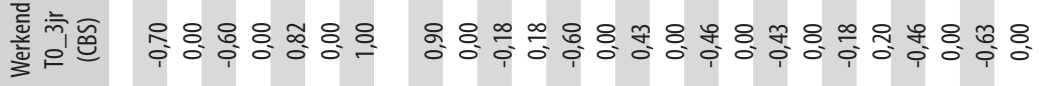

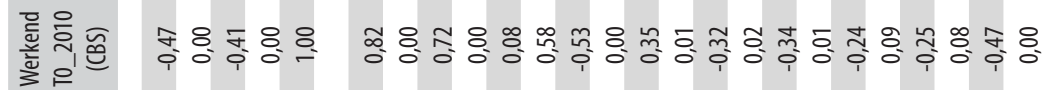

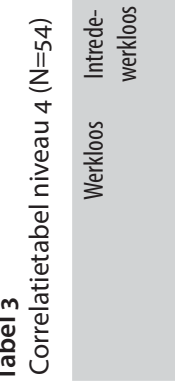

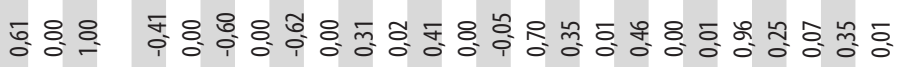

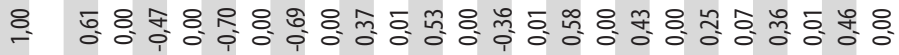

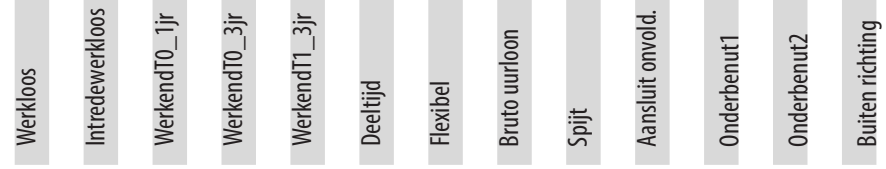


Bijlage tabel hoofdstuk 4 
Tabel 1

Regressiecoefficienten van model waarin het percentage werkenden wordt geschat op basis van de kenmerken leerweg, niveau, opleidingsrichting en regio

\begin{tabular}{|c|c|c|c|c|c|c|}
\hline werk12uurregio & Coef. & Std. Err. & $\mathrm{t}$ & $P>t$ & [95\% Conf. & Interval] \\
\hline Constant* & 68 & 1.24 & 54.86 & 0.00 & 65.68 & 70.55 \\
\hline \multicolumn{7}{|l|}{ BOL (ref.) } \\
\hline BBL & 17.82 & 0.39 & 46.23 & 0.00 & 17.07 & 18.58 \\
\hline \multicolumn{7}{|l|}{ niv2 (ref.) } \\
\hline niv3 & 7.06 & 0.46 & 15.33 & 0.00 & 6.16 & 7.97 \\
\hline niv4 & 10.53 & 0.46 & 22.66 & 0.00 & 9.62 & 11.44 \\
\hline \multicolumn{7}{|l|}{ MBO economie (ref.) } \\
\hline MB0 gezondheidszorg & 7.22 & 0.68 & 10.69 & 0.00 & 5.90 & 8.55 \\
\hline MB0 groen & 2.55 & 0.92 & 2.79 & 0.01 & 0.76 & 4.35 \\
\hline MBO overig & -1.95 & 1.18 & -1.65 & 0.10 & -4.26 & 0.36 \\
\hline MBO sociaal-cultureel & 3.30 & 0.51 & 6.48 & 0.00 & 2.30 & 4.30 \\
\hline MBO techniek & 5.23 & 0.46 & 11.26 & 0.00 & 4.32 & 6.14 \\
\hline \multicolumn{7}{|l|}{ Achterhoek (ref.) } \\
\hline Amsterdam (Groot) & -7.39 & 1.41 & -5.22 & 0.00 & -10.16 & -4.61 \\
\hline Brabant (Midden) & 0.93 & 1.49 & 0.62 & 0.53 & -1.99 & 3.84 \\
\hline Brabant (Noord-0ost) & 1.24 & 1.41 & 0.88 & 0.38 & -1.53 & 4.01 \\
\hline Brabant (West) & -1.25 & 1.42 & -0.88 & 0.38 & -4.03 & 1.53 \\
\hline Brabant (Zuid-0ost) & -1.22 & 1.49 & -0.82 & 0.41 & -4.15 & 1.71 \\
\hline Drechtsteden & 1.28 & 1.64 & 0.78 & 0.44 & -1.94 & 4.50 \\
\hline Drenthe & 0.26 & 1.55 & 0.17 & 0.87 & -2.78 & 3.30 \\
\hline Flevoland & -1.09 & 1.50 & -0.73 & 0.47 & -4.02 & 1.85 \\
\hline Food Valley & 4.34 & 1.59 & 2.73 & 0.01 & 1.22 & 7.47 \\
\hline Friesland & -2.67 & 1.44 & -1.85 & 0.06 & -5.49 & 0.15 \\
\hline Gelderland (Midden) & -1.85 & 1.56 & -1.18 & 0.24 & -4.91 & 1.21 \\
\hline Gelderland (Zuid) & -1.34 & 1.69 & -0.80 & 0.43 & -4.65 & 1.97 \\
\hline Gooi- en Vechtstreek & -0.73 & 1.95 & -0.37 & 0.71 & -4.54 & 3.09 \\
\hline Gorinchem & 4.54 & 1.95 & 2.33 & 0.02 & 0.73 & 8.36 \\
\hline Groningen & -3.78 & 1.39 & -2.72 & 0.01 & -6.50 & -1.06 \\
\hline Haaglanden & -3.42 & 1.46 & -2.35 & 0.02 & -6.28 & -0.56 \\
\hline Helmond-De Peel & 2.53 & 1.68 & 1.51 & 0.13 & -0.76 & 5.82 \\
\hline Holland (Midden) & 0.19 & 1.80 & 0.11 & 0.92 & -3.34 & 3.72 \\
\hline Holland (Rijnland) & 1.30 & 1.52 & 0.85 & 0.40 & -1.69 & 4.28 \\
\hline IJsselvechtstreek & 0.80 & 1.45 & 0.55 & 0.58 & -2.06 & 3.65 \\
\hline Kennemerland (Zuid) & -0.13 & 1.61 & -0.08 & 0.94 & -3.29 & 3.02 \\
\hline Limburg (Midden) & -0.63 & 1.77 & -0.36 & 0.72 & -4.10 & 2.84 \\
\hline Limburg (Noord) & 2.57 & 1.65 & 1.56 & 0.12 & -0.67 & 5.80 \\
\hline Limburg (Zuid) & -3.42 & 1.45 & -2.35 & 0.02 & -6.27 & -0.57 \\
\hline Noord-Holland (Noord) & 0.85 & 1.41 & 0.60 & 0.55 & -1.91 & 3.61 \\
\hline Rijnmond & -3.77 & 1.35 & -2.80 & 0.01 & -6.41 & -1.13 \\
\hline Rivierenland & 2.77 & 1.66 & 1.67 & 0.10 & -0.48 & 6.02 \\
\hline Stedendriehoek & 1.15 & 1.42 & 0.81 & 0.42 & -1.64 & 3.94 \\
\hline
\end{tabular}




\begin{tabular}{lcccccc} 
werk12uurregio & Coef. & Std. Err. & $\mathrm{t}$ & $\mathrm{P}>\mathrm{t}$ & [95\% Conf. & Interval] \\
\hline Twente & -1.76 & 1.46 & -1.21 & 0.23 & -4.62 & 1.10 \\
\hline Utrecht (Midden) & -1.39 & 1.42 & -0.98 & 0.33 & -4.17 & 1.39 \\
\hline Utrecht (0ost) & -0.49 & 1.66 & -0.29 & 0.77 & -3.74 & 2.76 \\
\hline Zaanstreek/Waterland & 0.43 & 1.59 & 0.27 & 0.79 & -2.68 & 3.55 \\
\hline Zeeland & 1.50 & 1.54 & 0.97 & 0.33 & -1.52 & 4.53 \\
\hline Zoetermeer & -0.75 & 1.68 & -0.45 & 0.66 & -4.04 & 2.54
\end{tabular}

* Percentage werkenden voor beroepsopleidingen niveau 2, leerweg BOL, economische richting in de Achterhoek 



\section{Bijlage tabellen hoofdstuk 5}




\section{Tabel 1}

Overzicht van beroepsopleidingen die niet voldoen aan de streefwaarde van $80 \%$ werkzaam

\begin{tabular}{|c|c|c|c|c|}
\hline Beroepsopleiding & Leerweg & Niveau & Aantal regio's & Aantal deelnemers \\
\hline Administratief medewerker & bbl & 2 & 3 & 49 \\
\hline Administratief medewerker & bol & 2 & 20 & 5.548 \\
\hline Analist & bol & 4 & 1 & 160 \\
\hline Applicatie- en mediaontwikkeling & bol & 4 & 1 & 273 \\
\hline Artiest & bol & 4 & 3 & 629 \\
\hline Autotechniek & $\mathrm{bbl}$ & 2 & 2 & 96 \\
\hline Autotechniek & bol & 2 & 4 & 484 \\
\hline AV-productie & bol & 4 & 4 & 419 \\
\hline Bedrijfsmanagement Mobiliteitsbranche & bol & 4 & 1 & 29 \\
\hline Bloemendetailhandel & bol & 3 & 1 & 21 \\
\hline Commercieel medewerker & bol & 3 & 7 & 1.127 \\
\hline Commercieel medewerker bank- en verzekeringswezen & bol & 4 & 6 & 554 \\
\hline Dierverzorging 2 & bol & 2 & 4 & 294 \\
\hline DTP-er & bol & 3 & 2 & 122 \\
\hline Facilitaire dienstverlener & $\mathrm{bbl}$ & 2 & 1 & 43 \\
\hline Facilitaire dienstverlener & bol & 2 & 2 & 81 \\
\hline Facilitaire dienstverlener & bol & 4 & 4 & 354 \\
\hline Fastservice & bbl & 2 & 2 & 70 \\
\hline Financiële beroepen & bol & 2 & 1 & 1 \\
\hline Financiële beroepen & bol & 3 & 10 & 3.074 \\
\hline Financiële beroepen & bol & 4 & 11 & 2.684 \\
\hline Frontofficemedewerker & bol & 3 & 1 & 12 \\
\hline Frontofficemedewerker & bol & 4 & 3 & 289 \\
\hline Gespecialiseerde dierverzorging gezelschapsdieren & bol & 3 & 4 & 38 \\
\hline Gezelschapsdierenbranche & bol & 4 & 2 & 7 \\
\hline Helpende Zorg \& Welzijn & bol & 2 & 34 & 14.904 \\
\hline ICT- en mediabeheer & bol & 4 & 9 & 1.971 \\
\hline ICT-medewerker & bol & 2 & 10 & 1.344 \\
\hline ICT-medewerker & bol & 3 & 26 & 4.541 \\
\hline Installeren & bol & 2 & 4 & 691 \\
\hline Interieuradviseur & bol & 4 & 4 & 673 \\
\hline Juridisch medewerker & bol & 4 & 8 & 2.420 \\
\hline Kapper & $\mathrm{bbl}$ & 2 & 1 & 45 \\
\hline Kapper & bol & 2 & 2 & 463 \\
\hline Kapper & bol & 3 & 7 & 504 \\
\hline Kok & $\mathrm{bbl}$ & 2 & 9 & 681 \\
\hline Kok & bol & 2 & 9 & 1.107 \\
\hline Kok & $\mathrm{bbl}$ & 3 & 3 & 152 \\
\hline Koopvaardij officier alle schepen & bol & 4 & 2 & 424 \\
\hline Laboratoriummedewerker & bol & 3 & 1 & 80 \\
\hline Leisure \& hospitality & bol & 3 & 3 & 238 \\
\hline Leisure \& hospitality & bol & 4 & 8 & 1.250 \\
\hline Logistiek supervisor & bol & 4 & 4 & 264 \\
\hline
\end{tabular}




\begin{tabular}{|c|c|c|c|c|}
\hline Logistiek teamleider & bol & 3 & 1 & 60 \\
\hline Luchtvaartdienstverlener & bol & 4 & 3 & 607 \\
\hline Luchtvaartlogisticus & bol & 4 & 1 & 20 \\
\hline Maatschappelijke Zorg & bol & 4 & 1 & 288 \\
\hline Manager handel & bol & 4 & 22 & 3.722 \\
\hline Mbo-Verpleegkundige & bol & 4 & 1 & 413 \\
\hline Medewerker bediening/caf,-bar & bol & 2 & 2 & 230 \\
\hline Medewerker bediening/caf,-bar & bol & 4 & 1 & 4 \\
\hline Medewerker havenoperaties & bbl & 2 & 1 & 5 \\
\hline Medewerker marketing en communicatie & bol & 4 & 16 & 6.052 \\
\hline Medewerker operationele techniek & bol & 2 & 1 & 104 \\
\hline Medewerker schilderen & $\mathrm{bbl}$ & 2 & 1 & 29 \\
\hline Medewerker stukadoren & bbl & 2 & 1 & 18 \\
\hline Mediamanagement & bol & 4 & 2 & 325 \\
\hline Mediavormgever & bol & 4 & 24 & 8.431 \\
\hline Metaalbewerken & $\mathrm{bbl}$ & 2 & 1 & 26 \\
\hline Metaalbewerken & bol & 2 & 1 & 103 \\
\hline Meubelmaker/(scheeps)interieurbouwer & bol & 2 & 3 & 197 \\
\hline Middenkader engineering & bol & 4 & 1 & 167 \\
\hline Middenkaderfunctionaris afbouw en onderhoud & bol & 4 & 1 & 157 \\
\hline Middenkaderfunctionaris bouw en infra & bol & 4 & 3 & 453 \\
\hline Natuur en groene ruimte 3 & bol & 3 & 1 & 43 \\
\hline Natuur en groene ruimte 4 & bol & 4 & 2 & 266 \\
\hline Natuur en vormgeving & bol & 4 & 1 & 56 \\
\hline Ondernemer detailhandel & bol & 4 & 16 & 1.894 \\
\hline Ondernemer horeca/bakkerij & $\mathrm{bbl}$ & 4 & 1 & 12 \\
\hline Ondernemer horeca/bakkerij & bol & 4 & 12 & 2.949 \\
\hline Onderwijsassistent & bbl & 4 & 1 & 2 \\
\hline Onderwijsassistent & bol & 4 & 22 & 6.994 \\
\hline Operationele techniek & bol & 4 & 1 & 205 \\
\hline Paraveterinaire ondersteuning & bol & 4 & 2 & 159 \\
\hline Particuliere beveiliging & $\mathrm{bbl}$ & 2 & 2 & 131 \\
\hline Particuliere beveiliging & bol & 2 & 28 & 3.779 \\
\hline Pedagogisch Werk & bbl & 3 & 2 & 9 \\
\hline Pedagogisch Werk & bol & 3 & 7 & 4.091 \\
\hline Pedicure & bol & 3 & 1 & 8 \\
\hline Podium- en evenemententechniek & bol & 4 & 1 & 111 \\
\hline Printmedia & bol & 4 & 1 & 11 \\
\hline Productiecoördinator fashion & bol & 4 & 1 & 15 \\
\hline Productiedieren & bol & 3 & 3 & 198 \\
\hline Productiedieren & bol & 4 & 5 & 516 \\
\hline Recreatiedieren & bol & 3 & 5 & 399 \\
\hline Recreatiedieren & bol & 4 & 1 & 73 \\
\hline Reizen & bol & 3 & 7 & 454 \\
\hline Reizen & bol & 4 & 12 & 890 \\
\hline Schoonheidsspecialist & bol & 3 & 24 & 2.528 \\
\hline
\end{tabular}




\begin{tabular}{lcccc}
\hline Schoonheidsspecialist & bol & 4 & 5 & 577 \\
\hline Secretariële beroepen & bbl & 3 & 1 & 39 \\
Secretariële beroepen & bol & 3 & 7 & 1.036 \\
\hline Secretariële beroepen & bbl & 4 & 1 & 30 \\
Secretariële beroepen & bol & 4 & 6 & 1.003 \\
\hline Sociaal-cultureel werker & bbl & 4 & 2 & 13 \\
\hline Sociaal-cultureel werker & bol & 4 & 14 & 1.662 \\
\hline Sport en bewegen & bol & 3 & 9 & 2.009 \\
\hline Sport en bewegen & bol & 4 & 18 & 5.389 \\
\hline Sport- en bewegingsbegeleider & bol & 2 & 4 & 401 \\
\hline Tandartsassistent & bol & 4 & 1 & 56 \\
\hline Timmerman & bbl & 2 & 6 & 255 \\
Timmerman & bol & 2 & 3 & 201 \\
\hline Vakman gww & bbl & 3 & 1 & 3 \\
\hline Veiligheid en vakmanschap & bol & 2 & 24 & 2.023 \\
\hline Verkoopspecialist & bol & 3 & 18 & 3.860 \\
Verkoper & bol & 2 & 21 & 4.571 \\
\hline Vliegtuigonderhoud Part-66 & bol & 4 & 1 & 125 \\
\hline Vormgeving ruimtelijke presentatie en communicatie & bol & 4 & 7 & 1.225 \\
\hline Werkvoorbereider houtbranche & bol & 4 & 2 & 27 \\
\hline Totaal & & & & 119.919 \\
\hline Bron: CBS/SSB, OCW/DUO & & & & \\
\hline
\end{tabular}


Tabel 2

Overzicht van $10 \%$ van beroepsopleidingen met het laagste percentage werkzaam, gecorrigeerd voor opleidingskenmerken

\begin{tabular}{|c|c|c|c|c|}
\hline Beroepsopleiding & Leerweg & Niveau & Aantal regio's & Aantal deelnemers \\
\hline Administratief medewerker & bol & 2 & 19 & 4.666 \\
\hline Artiest & bol & 4 & 2 & 378 \\
\hline Autotechniek & $\mathrm{bbl}$ & 2 & 1 & 96 \\
\hline Autotechniek & bol & 2 & 1 & 72 \\
\hline AV-productie & bol & 4 & 1 & 37 \\
\hline Commercieel medewerker & bol & 3 & 1 & 340 \\
\hline Dierverzorging 2 & bol & 2 & 3 & 251 \\
\hline Doktersassistent & bbl & 4 & 1 & 7 \\
\hline DTP-er & bol & 3 & 1 & 51 \\
\hline Facilitaire dienstverlener & bbl & 2 & 1 & 43 \\
\hline Facilitaire dienstverlener & bol & 2 & 1 & 17 \\
\hline Fastservice & bbl & 2 & 1 & 28 \\
\hline Financiële beroepen & bol & 3 & 1 & 691 \\
\hline Frontofficemedewerker & bol & 4 & 2 & 185 \\
\hline Gespecialiseerde dierverzorging gezelschapsdieren & bol & 3 & 3 & 34 \\
\hline Gezelschapsdierenbranche & bol & 4 & 1 & 1 \\
\hline Helpende Zorg \& Welzijn & bol & 2 & 6 & 4.418 \\
\hline ICT- en mediabeheer & bol & 4 & 3 & 375 \\
\hline ICT-medewerker & bol & 2 & 6 & 910 \\
\hline ICT-medewerker & bol & 2 & 1 & 190 \\
\hline ICT-medewerker & bol & 3 & 6 & 753 \\
\hline Interieuradviseur & bol & 4 & 2 & 224 \\
\hline Juridisch medewerker & bol & 4 & 4 & 976 \\
\hline $\begin{array}{l}\text { Kaderfunctionaris bouw, infra en gespecialiseerde } \\
\text { aannemerij }\end{array}$ & bbl & 4 & 2 & 10 \\
\hline Kapper & bbl & 3 & 1 & 7 \\
\hline Kapper & bol & 3 & 1 & 19 \\
\hline Kok & bbl & 2 & 9 & 681 \\
\hline Kok & bol & 2 & 5 & 710 \\
\hline Kok & bbl & 3 & 11 & 767 \\
\hline Koopvaardij officier alle schepen & bol & 4 & 1 & 192 \\
\hline Leisure \& hospitality & bol & 3 & 2 & 169 \\
\hline Leisure \& hospitality & bol & 4 & 1 & 211 \\
\hline Logistiek supervisor & bol & 4 & 3 & 249 \\
\hline Logistiek teamleider & bbl & 3 & 1 & 35 \\
\hline Luchtvaartdienstverlener & bol & 4 & 1 & 200 \\
\hline Manager handel & bol & 4 & 3 & 876 \\
\hline Medewerker marketing en communicatie & bol & 4 & 3 & 1.316 \\
\hline Medewerker schilderen & bbl & 2 & 1 & 29 \\
\hline Medewerker stukadoren & bbl & 2 & 1 & 18 \\
\hline Mediavormgever & bol & 4 & 22 & 7.822 \\
\hline Meubelmaker/(scheeps)interieurbouwer & bbl & 3 & 1 & 17 \\
\hline
\end{tabular}




\begin{tabular}{|c|c|c|c|c|}
\hline Middenkaderfunctionaris bouw en infra & bol & 4 & 1 & 109 \\
\hline Natuur en groene ruimte 4 & bol & 4 & 1 & 210 \\
\hline Ondernemer detailhandel & bol & 4 & 7 & 764 \\
\hline Ondernemer horeca/bakkerij & bbl & 4 & 2 & 71 \\
\hline Onderwijsassistent & $\mathrm{bbl}$ & 4 & 1 & 2 \\
\hline Onderwijsassistent & bol & 4 & 1 & 206 \\
\hline Particuliere beveiliging & bol & 2 & 1 & 59 \\
\hline Pedagogisch Werk & $\mathrm{bbl}$ & 3 & 6 & 26 \\
\hline Pedicure & bol & 3 & 1 & 8 \\
\hline Printmedia & bol & 4 & 1 & 11 \\
\hline Productiedieren & bol & 3 & 1 & 54 \\
\hline Productiedieren & bol & 4 & 1 & 249 \\
\hline Recreatiedieren & bol & 3 & 1 & 181 \\
\hline Reizen & bol & 4 & 6 & 439 \\
\hline Schoonheidsspecialist & bol & 3 & 10 & 894 \\
\hline Schoonheidsspecialist & bol & 4 & 2 & 172 \\
\hline Secretariële beroepen & bbl & 3 & 1 & 39 \\
\hline Secretariële beroepen & $\mathrm{bbl}$ & 4 & 1 & 30 \\
\hline Secretariële beroepen & bol & 4 & 1 & 113 \\
\hline Sociaal-cultureel werker & $\mathrm{bbl}$ & 4 & 2 & 13 \\
\hline Sociaal-cultureel werker & bol & 4 & 11 & 1.063 \\
\hline Sport en bewegen & bol & 3 & 6 & 1.554 \\
\hline Sport en bewegen & bol & 4 & 11 & 2.959 \\
\hline Sport- en bewegingsbegeleider & bol & 2 & 1 & 159 \\
\hline Timmerman & bbl & 2 & 7 & 308 \\
\hline Timmerman & bol & 2 & 1 & 105 \\
\hline Timmerman & bbl & 3 & 1 & 21 \\
\hline Vakman gww & $\mathrm{bbl}$ & 3 & 1 & 3 \\
\hline Verkoopspecialist & bol & 3 & 5 & 1.518 \\
\hline Verkoper & bol & 2 & 15 & 3.535 \\
\hline Vormgeving ruimtelijke presentatie en communicatie & bol & 4 & 4 & 767 \\
\hline $\begin{array}{l}\text { Totaal } \\
\text { Bron: CBS/SSB, OCW/DUO }\end{array}$ & & & & 43.713 \\
\hline
\end{tabular}


Tabel 3

Overzicht van $6 \%$ beroepsopleidingen in onderste $10 \%$-groep voor percentage werkzaam, ongecorrigeerd en gecorrigeerd voor opleidingskenmerken

\begin{tabular}{|c|c|c|c|c|}
\hline Beroepsopleiding & Leerweg & Niveau & $\begin{array}{l}\text { Aantal } \\
\text { regio's }\end{array}$ & Aantal deelnemers \\
\hline Administratief medewerker & bol & 2 & 18 & 4.643 \\
\hline Artiest & bol & 4 & 2 & 378 \\
\hline Autotechniek & bol & 2 & 1 & 72 \\
\hline Commercieel medewerker & bol & 3 & 1 & 340 \\
\hline Dierverzorging 2 & bol & 2 & 3 & 251 \\
\hline DTP-er & bol & 3 & 2 & 122 \\
\hline Facilitaire dienstverlener & bbl & 2 & 1 & 43 \\
\hline Facilitaire dienstverlener & bol & 2 & 1 & 17 \\
\hline Financiële beroepen & bol & 3 & 1 & 691 \\
\hline Frontofficemedewerker & bol & 4 & 1 & 64 \\
\hline Gespecialiseerde dierverzorging gezelschapsdieren & bol & 3 & 3 & 34 \\
\hline Helpende Zorg \& Welzijn & bol & 2 & 6 & 4.418 \\
\hline ICT- en mediabeheer & bol & 4 & 2 & 304 \\
\hline ICT-medewerker & bol & 3 & 12 & 1.846 \\
\hline Interieuradviseur & bol & 4 & 2 & 224 \\
\hline Juridisch medewerker & bol & 4 & 3 & 814 \\
\hline Kapper & bol & 3 & 1 & 19 \\
\hline Kok & bol & 2 & 6 & 783 \\
\hline Koopvaardij officier alle schepen & bol & 4 & 1 & 192 \\
\hline Leisure \& hospitality & bol & 4 & 3 & 380 \\
\hline Manager handel & bol & 4 & 3 & 876 \\
\hline Medewerker marketing en communicatie & bol & 4 & 2 & 952 \\
\hline Mediavormgever & bol & 4 & 11 & 4.288 \\
\hline Natuur en groene ruimte 4 & bol & 4 & 1 & 210 \\
\hline Ondernemer detailhandel & bol & 4 & 7 & 764 \\
\hline Onderwijsassistent & bol & 4 & 1 & 206 \\
\hline Particuliere beveiliging & bol & 2 & 1 & 59 \\
\hline Pedicure & bol & 3 & 1 & 8 \\
\hline Printmedia & bol & 4 & 1 & 11 \\
\hline Productiedieren & bol & 3 & 1 & 54 \\
\hline Productiedieren & bol & 4 & 2 & 249 \\
\hline Recreatiedieren & bol & 3 & 2 & 181 \\
\hline Reizen & bol & 4 & 5 & 412 \\
\hline Schoonheidsspecialist & bol & 3 & 9 & 780 \\
\hline Schoonheidsspecialist & bol & 4 & 1 & 21 \\
\hline Secretariële beroepen & bol & 4 & 1 & 113 \\
\hline Sociaal-cultureel werker & bbl & 4 & 1 & 3 \\
\hline Sociaal-cultureel werker & bol & 4 & 8 & 866 \\
\hline Sport en bewegen & bol & 3 & 3 & 948 \\
\hline Sport en bewegen & bol & 4 & 3 & 450 \\
\hline Sport- en bewegingsbegeleider & bol & 2 & 1 & 159 \\
\hline
\end{tabular}


Bijlage tabellen hoofdstuk 5

$\begin{array}{lrrrr}\text { Timmerman } & \text { bol } & 2 & 1 & 105 \\ \text { Verkoopspecialist } & \text { bol } & 3 & 5 & 1.518 \\ \text { Verkoper } & \text { bol } & 2 & 15 & 3.535 \\ \text { Vormgeving ruimtelijke presentatie en communicatie } & \text { bol } & 4 & 4 & 767 \\ \text { Totaal } & & & & 33.170 \\ \text { Bron: CBS/SSB, OCW/DUO } & & & \end{array}$

